National library

ol Canada

Acquisitions and

Bibliographic Services Branch

395 Wellington Street

Ottawn, Ontatro

KIA ON4
Bibliotheque nalionale

du Canada

Direction des acquisitions el

des services bibliographiques

395. rue Wellingion

Ottawa (Ontatio)

KIAONA

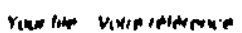

Che his Materetionemice

NOTICE

AVIS

The quality of this microform is heavily dependent upon the quality of the original thesis submitted for microfilming. Every effort has been made to ensure the highest quality of reproduction possible.

If pages are missing, contact the university which granted the degree.

Some pages may have indistinct print especially if the original pages were typed with a poor typewriter ribbon or if the university sent us an inferior photocopy.

Reproduction in full or in part of this microform is governed by the Canadian Copyright Act, R.S.C. 1970, c. C-30, and subsequent amendments.
La qualité de cette microforme dépend grandement de la qualité de la thèse soumise au microfilmage. Nous avons tout fait pour assurer une qualité supérieure de reproduction.

S'il manque des pages, veuillez communiquer avec l'université qui a conféré le grade.

La qualité d'impression de certaines pages peut laisser à désirer, surtout si les pages originales ont été dactylographiées à l'aide d'un ruban usé ou si l'université nous a fait parvenir une photocopie de qualité inférieure.

La reproduction, même partielle, de cette microforme est soumise à la Loi canadienne sur le droit d'auteur, SRC 1970, c. C-30, et ses amendements subséquents. 


\title{
Methane Dynamics of a Northern Boreal Beaver Pond
}

\author{
A thesis submitted to the Faculty of Graduate Studies and Research \\ in partial fulfillment of the requirements for the degree of \\ Master of Science by \\ (c) Alice E. Dove \\ 1995
}

Department of Geography

McGill University

Montreal, Quebec 
National Library

of Canada

Acquisitions and

Bibliographic Services Branch

395 Wellington Street

Ottawa, Ontario

KIA ON4
Bibliothèque nationale

du Canada

Direction des acquisitions et

des services bibliographiques

395, rue Wollinglon

Ottawa (Ontario)

You tile votro peterence

The author has granted an irrevocable non-exclusive licence allowing the National Library of Canada to reproduce, loan, distribute or sell copies of his/her thesis by any means and in any form or format, making this thesis available to interested persons.
L'auteur a accordé une licence irrévocable et non exclusive permettant à la Bibliothèque nationale du Canada de reproduire, prêter, distribuer ou vendre des copies de sa thèse de quelque manière et sous quelque forme que ce soit pour mettre des exemplaires de cette thèse à la disposition des personnes intéressées.

L'auteur conserve la propriété du droit d'auteur qui protège sa thèse. Ni la thèse ni des extraits substantiels de celle-ci ne doivent être imprimés ou autrement reproduits sans son autorisation.

ISBN $\quad 0-612-12183-6$ 
Alstract

Résumí

Acknowledgements

l.jist of "I ables

list ol rigures

1.) Introduction

\section{Chapter 1: Introduction}

I.I Aimospheric Methane

1.2 Sources of Methane

1.3 Prouesses Allecting Methane Lit.issions from Freshwater Wetlands

1.4 controls of Methane Flux from Wetlands

1.5 Beaver Ponds as a Source of Atmospheric Methane

1 .o Conceptual Model of Methane Dymanics in Beatver Ponds

I.7 Slully Objectives

Chapter 2: Study Site and Methodology

2.0 The Boreal-Forest Ecosystem-Atmosphere Study

2. I Stidy Site

2.2 Field Methods

2.2.1 liloating Chamber Flux Measurements

2.2.2 Bubble Flux Measurements

2.2 .3 Porewater $\mathrm{CH}_{4}$ Siorage $\quad 24$

2.2.4 Sediment-Water Interface $\mathrm{CH}_{4}$ Protiles $\quad 25$

2.2.5 Water Column $\mathrm{CH}_{4}$ Profiles $\quad 26$

2.2.6 Surface-Water $\mathrm{CH}_{4}$ Concentrations $\quad 26$

2.2.7 Flux of $\mathrm{CH}_{4}$ across the Sediment-Water Interface 26

$\begin{array}{ll}2.2 .8 \text { Environmental Variables } & 27\end{array}$

$2.3 \mathrm{I}$ abc ratory Methods 28

2.3.1 $\mathrm{CH}_{\text {: }}$ Analysis $\quad 28$

2.3.2 Sediment Sample Incubations $\quad 29$

2.3.3 Isotopic Analysis $\quad 30$

2.4 Data Analysis

3.1 Environmental Variables

\section{Chapter 3: Results}

3.2 Chamber Fluxes $\quad 37$

3.2.1 Vegetation and Site Differences $\quad 37$

3.2.2 Seasonal Trends and Spatial Variability 39

3.2.3 Relationships between Chamber Fluxes and Environmental Variables $\quad 42$

3.2.4 Dicl Chamber Fluxes 48 


\section{Table of Contents cont.}

3.3 Bubble Fluxes

3.3.1 Vegetation and Site Miflerences

3.3.2 Seasomal Trends and Flux Variability 5.1

3.3.3 Relationships between Bubble filuxes and linvironmental Variabies $\quad 5.4$

3.3.4 Bubble Release from Storage 50)

3.3.5 Gross Bubbie Storage and Production

3.3.6 lsotopic Analysis of Bubble $\mathrm{CH}_{4}$

3.4 Sediment-Water Fluxes

3.4.1 Sediment and Water Columm $\mathrm{CH}_{4}$ Oxidation $\quad 67$

3.5 Sediment-Water Interface $\mathrm{CH}_{4}$ Protiles

3.6 Water Column $\mathrm{CH}_{4}$ Proliles

3.6.1 Isotopic Composition of $\mathrm{CH}_{4}$ in the Water Column

3.7 Porewater $\mathrm{CH}_{4}$ from Piezometers 76

3.7.1 Isotopic Composition of Porewater $\mathrm{CH}_{4}$

3.8 Laboratory Incubations

4.0 Introduction 85

4.1 Total $\mathrm{CH}_{4}$ Emissions

4.1.1 Comparison with Flux Measured from other Beaver Ponds 89

4.1.2 Regional Significance of $\mathrm{CH}_{4}$ Emissions from Beaver Ponds

$\begin{array}{ll}4.2 \text { Error Analysis } & 92\end{array}$

4.2.1 Flux Variability

4.2.2 Flux Accuracy: Comparison with Continuous Tower $\mathrm{CH}_{4}$ Flux 95 Measurements

4.2.3 Arithmetic vs. Geometric Means $\quad 97$

4.2.4 Possible Errors in Floating Chamber Measurements

$\begin{array}{ll}\text { 4.3.5 Winter } \mathrm{CH}_{4} \text { Emissions } & 103\end{array}$

4.3 Environmental Controls of $\mathrm{CH}_{4}$ Emissions

$\begin{array}{ll}\text { 4.3.1 Primary Controls on } \mathrm{CH}_{4} \text { Availability } & 105\end{array}$

$\begin{array}{ll}\text { 4.3.2 Secondary Controls on } \mathrm{CH}_{4} \text { Release: Diffusion } & 107\end{array}$

4.3.3 Secondary Controls on $\mathrm{CH}_{4}$ Release: Bubbles 109

4.3.4 Secondary Controls on $\mathrm{Cl}_{4}$ Release: Plant Transport $\quad$ II

4.4 $\mathrm{CH}_{4}$ Dynamics in the Beaver Pond $\quad 114$

$\begin{array}{ll}\text { 4.4.1 Storage } & 114\end{array}$

$\begin{array}{ll}4.4 .2 \mathrm{CH}_{4} \text { Production } & 115\end{array}$

$\begin{array}{ll}4.4 .3 \mathrm{CH}_{4} \text { Oxidation } & 119\end{array}$

$\begin{array}{ll}4.5 \text { Summary and Conclusions } & 125\end{array}$

$\begin{array}{ll}\text { References Cited } & 129\end{array}$

Appendix I: Data Available through BORIS (BOREAS Information Systems)

Appendix I: Julian Day - Calendar Day Conversion Table $\quad 136$ 


\begin{abstract}
Alsstract
Most global and regional "greenhouse gas" budgets have neglected beaver ponds, but they have been found to be relatively high emitters of methane $\left(\mathrm{CH}_{4}\right)$ (Roulet et al, 1992). Static chambers, bubble traps, benthic chambers, piezometers, and water column and sediment profiles were used to determine the dynamics of $\mathrm{CH}_{4}$ production, oxidation, storage, and emissions from a northern boreal beaver pond, as part of the Boreal Forest licosystem-Atmosphere Study (BOREAS) from May 1 to Septenber 15, 1994. Samples were analysed by gas chromatography, and isotopic analyses were performed by mass spectrometry.

The mean flux of $\mathrm{Cl}_{4}$ from the beaver pond (155 and $320 \mathrm{mg} \mathrm{CH}_{4} \mathrm{~m}^{-2} \mathrm{~d}^{-1}$ for vegetated and open water sites, respectively) was greater than the flux from most other northern boreal wetlands (Bubier et al, 1995), $\mathrm{CH}_{4}$ availability was primarily controlled by sediment temperature, and $\mathrm{CH}_{4}$ transport was controlled by windspeed (diffusion) and atmospheric pressure (bubbles). Bubbles comprised 20 to $52 \%$ of the net annual flux ( $18.2 \mathrm{~g} \mathrm{CH}_{4} \mathrm{~m}^{-2} \mathrm{yr}^{-1}$ ), with diffusion comprising the remainder. A large difference in bubble flux was observed between open water $\left(15.7 \mathrm{~g} \mathrm{CH}_{4} \mathrm{~m}^{-2} \mathrm{yr}^{-1}\right)$ and vegetated sites $\left(2.9 \mathrm{~g} \mathrm{CH}_{4} \mathrm{~m}^{-2} \mathrm{yr}^{-1}\right)$, and isotopic analyses indicate that this difference is due, in part, to a diflerence in $\mathrm{CH}_{4}$ production pathways between sites. Greater oxidation also reduced the $\mathrm{CH}_{4}$ flux from shallow, vegetated sites.

A preliminary $\mathrm{CH}_{4}$ budget for the BOREAS northern study area indicates that beaver ponds contribute significantly $(6 \%$ to $30 \%)$ to the regional $\mathrm{CH}_{4}$ flux. The areal extent of beaver ponds needs to be determined for inclusion in regional and global $\mathrm{CH}_{4}$ budgets.
\end{abstract}




\section{Résumí}

La plupart des budgets des ..gaz d'effet de serre" nöinclus pas les laes a castors. Pourtant, ces bassins émettent une quantite de methane ( $\left(1 l_{1}\right)$ relativement elevé (Roulet et al., 1992). La production, l'oxydation, le stockage, el le llux de $\mathrm{CH} \mathrm{H}_{1}$ dans un lac a castors au nord du Manitoba ont été détermines par des enceintes static|ues, des pieges a bulles, des enceintes au fond du bassin, des echantillons de $\mathrm{CH}_{4}$ dans les eaux interstiticlle; et des profils d'eau et de sédiments. Cette étude, éflectuce du premicr mai a la miseptembre, 1994, a été réalisée dans le cadre du .Boreal Forest licosystem-Atmosphere Study" (BOREAS). Les échantillons de $\mathrm{Cl}_{4}$ ont éte analysés par la chromatographic des gaz et les analyses isotopiques de $\mathrm{CH}_{4}$ étaient accomplis par la spectrometrie de mass.

La moyenne des émissions de $\mathrm{CH}_{4}$ par le lac a castors (155 a $320 \mathrm{mg}\left(\mathrm{H}_{4} \mathrm{~m}^{-2} \mathrm{an}^{-1}\right)$ était plus élevée que la majorité de ceux obtenus à d'autres sites lourbeux (Bubier et al., sous presse). La disponibilité de $\mathrm{CH}_{4}$ était controllée principalement par la temperature au fond du bassin, et le transport de $\mathrm{CH}_{4}$ était controllé par la vitesse du vent (dilfusion) et par la pression de l'atmosphère (bouillonnement). Les bulles ont contribue de 20 a $52 \%$ des émissions annuelles $\left(18.2 \mathrm{~g} \mathrm{~m}^{-2} \mathrm{an}^{-1}\right)$ et la diffusion fut responsable de la balance. De grandes différences de bouillonnement ont été observées entre des sites végétaux $(2.9 \mathrm{~g}$ $\mathrm{CH}_{4} \mathrm{~m}^{-2} \mathrm{an}^{-1}$ ), et les sites non-végétaux (15.7 $\left.\mathrm{g} \mathrm{CH}_{4} \mathrm{~m}^{-2} \mathrm{an}^{-1}\right)$; les analyses isotopiques ayant indiqué que ces différences étaient en partie dù aux diffërents mécanismes chimique de la production de $\mathrm{CH}_{4}$. Plus d'oxydation a aussi réduit les emissions des sites peu profonds et végètaux.

Un budget préliminaire indique que les lacs à castors émettent de $6 \%$ a $30 \%$ de la flux de $\mathrm{CH}_{4}$ régionale, mais l'aire des bassins doit être mieux déterminé pour améliorer les budgets de $\mathrm{CH}_{4}$ régionaux et mondiaux. 
Acknowledgements

I would primarily like to thank my research supervisor, Prof. Nigel Roulet, for his inspiration and guidance. His patience and supervisory skills made for an exceptional gradtate experience. I also thank Prof. 'lim Moore for his insight and useful comments.

Jeff (hanton provided invaluable assistance and lab resources for analysis of isotopes of ${ }^{1.3} \mathrm{C}$ and deuterium (D), which comprised an important component of this research. Sue Trumbore collected and analysed sediment samples for radiocarbon isolopes.

Many assisted in field preparation, and data collection and processing. I particularly thank Carol Robinson (the original "Boreas Woman") and Jose Etcheverry for their assistance in the field, and Natalia Popowych for assisting the laboratory incubations. Many thanks io Rick Bourborniere for the use of his (superior) rubber boat and for the hydrolab data. Patrick Crill gave much needed guidance in the field and lab, and Dean Moosavi provided field assistance and answered seemingly infinite questions. Jill Bubier competently identified the aquatic macrophytes. Neil Comer assisted with measuring pond bathymetry and diel sampling ("Get up!"), and assured that the pond's micrometeorological tower and equipment were functioning properly. Shannon Glenn processed and quality-checked the tower data. Additional assistance was received from Mike Dalva, Paula Kestleman and Doug Barr at the Department of Geography, McGill University, and from Sarah Dalle and Mike Waddington in the field. Many thanks also to Lianne Bellisa-io, Kathleen Savage, and the other BOREAS researchers for companionship and inspiration while in Thompson.

I especially thank Laud Matos, who provided encouragement and insight throughout. Special appreciation also goes to my friends Stephanie Weinstein and Stevie Periman for keeping me laughing and (in)sane while analysing and writing.

This study was funded in part by the Centre for Climate and Global Change Research (C $\left.{ }^{2} \mathrm{GCR}\right)$.

I dedicate this work to the memory of my parents, John and Lois Dove. I only wish that they could share in this achievement. 


\section{List of Tialdes}

1 Atmospheric $\mathrm{CH}_{1}$ Budget

2.1 List of Vascular Plant Species at the Beaver Pond 21

2.2 Measurement of Environmental Variables 27

3.1 Chamber Flux Data by Vegetation Type 38

3.2 Spearman Pairwise Correlation Coefficients ( $r$ ) Between Mean Daily Chamber Fluxes and Environmental Variables

3.3 Spearman Pairwise Correlation Coeflicients ( $r$ Between Chamber liluxes and 47 Sediment Temperatures a) Julian Days 140-165: Increasing Sediment Temperatures; b) Julian Days 190-205: Increasing Sediment Temperatures; c) Julian Days 214-231 : Decreasing Sediment Temperatures: (with fluctuations)

3.4 Summary of Bubble Flux Data

3.5 Spearman Pairwise Correlation Coefficients ( $r$ ) Between Mean Daily Bubble 56 Fluxes and Environmental Variables

3.6 Spearman Correlation Coefficients ( $r$ ) Between 24-hour \% (hange in Bubble $\quad 62$ Fluxes and Porewater $\mathrm{CH}_{4}$ Concentrations

3.7 Fickian Sediment-Water Diffusive Fluxes Modelled from Peeper Protiles $\quad 73$

3.8 Potential Anaerobic $\mathrm{CH}_{4}$ Production and Aerobic $\mathrm{CH}_{4}$ Consumption of $\quad 82$ Beaver Pond Sediments Determined in the Laboratory

4.1 Summary of $\mathrm{CH}_{4}$ Flux from Beaver Ponds

4.2 $\mathrm{CH}_{4}$ Budget for the BOREAS Northern Study Area 9)

4.3 Comparison of $\mathrm{CH}_{4}$ Flux Measured Continuously at the Tower with Chamber 97 and Bubble Flux Measurements

4.4 Comparison of Annual $\mathrm{CH}_{4}$ Flux Calculated by Integrating Geometric and 99 Arithmetic Mean Daily Flux

4.5 Winter $\mathrm{CH}_{4}$ Emissions Calculated as the Difference between Fall and Spring 103 Porewater $\mathrm{CH}_{4}$ Storage 


\section{Lișt of lijgures}

1.1 I:stimated Annual (M. Emission Rates from Wetlands in Canada 2

1.2 Conceptual Model of Methane Dynamics in a Beaver Pond I.3

2.1 BORJ:AS Study Areats

2.2 Map of the Beaver Pond with Sampling Locations 20

3.1 a) Total Daily Precipitation and b) Beaver Pond Water Level 33

3.2 a) Mean Daily Air Temperature and b) Mean Daily Pond Water 34 T'emperature

3.3 Mean Daily Pond Sediment Temperature $\quad 35$

3.4 Mean Daily Daytime PAR and Underwater PAR 36

3.5 Mean Daily Atmospheric Pressure $\quad 36$

3.6 Distribution of $A$ ll Chamber Fluxes 38

3.7 Chamber Fluxes by Vegetation Type 38

3.8 Mcan Daily $\mathrm{CH}_{4}$ Flux from Floating Chambers and Cumulative Emissions 40

3.9 Late-Season Evidence for Enhancement of $\mathrm{CH}_{4}$ Flux by ('arex plants 43

3.10 Scatter Plot Matrices of Mean Daily Chamber Fluxes from Sedge (c'arex) 44 and Open Water Sites vs. Mean Daily a) Sediment Temperatures and b) Atmospheric Pressure, PAR, Pond Stage and Windspeed

3.11 Multiple Linear Regression Equations for Chamber Fluxes 46

3.12 Mean Daily Chamber Flux and $20 \mathrm{~cm}$ Sediment Temperature 49

3.13 Histogram of Diel Chamber Fluxes from a) June 20-21, 1994 and 50 b) July 8-9, 1994

3.14 Distributions of a) Open Water Bubble Fluxes and 52

b) Vegetated Site Bubble Fluxes

3.15 a) Differences between bubble fluxes from open water and vegetated sites 53 are due both to $\mathrm{b}$ ) differences in bubbling rates and c) differences in concentration of $\mathrm{CH}_{4}$ in bubbles

3.16 Mean Daily Bubble $\mathrm{CH}_{4}$ Flux and Cumulative Emissions

3.17 Mean Daily Bubble Flux with Mean Daily Atmospheric Pressure 57

3.18 Mean Daily Bubble Flux, Sediment Temperature and Pond Water Level 58

3.19 Regression Analysis of Mean Daily Open Water Bubble Fluxes 60

3.20 Regression Analysis of Mean Daily Vegetated Site Bubble Fluxes 61

3.21 Isotopic Composition of $\mathrm{CH}_{4}$ in Bubbles 64

3.22 Comparison of Water-Air and Sediment-Water $\mathrm{CH}_{4}$ Fluxes 68

3.23 a-h) Peeper Porewater $\mathrm{CH}_{4}$ Profiles $\quad 70$

3.24 Modelled Sediment-Water Diffusive $\mathrm{CH}_{4}$ Fluxes from Peeper Profiles and 72 Measured Water-Air Fluxes from Floating Chambers

$\begin{array}{lll}3.25 & \text { Water Column } \mathrm{CH}_{4} \text { Profiles } & 74\end{array}$

3.26 Porewater $\mathrm{CH}_{4}$ in 3 Piezometer Nests: a) Shallow $(0.4-0.2 \mathrm{~m})$ Nest; b) Intermediate (0.7 - $0.5 \mathrm{~m})$ Nest; c) Deep (2.2 - $2.0 \mathrm{~m})$ Nest 


\section{List of figures cont.}

3.27 Storage ol CH. Dissolved in Porewater (integrated to a depth of $1.5 \mathrm{~m} \mathrm{in} \quad 78$ sediments)

3.28 Isotopic Composition of Porewater $\mathrm{CH}_{4}$ with Line of Best fit, and Isofopic $\quad 79$ Composition of $\mathrm{CH}_{4}$ in the Water Column

3.29 Laboratory Incubations of Sediment Samples a) Polential ("H. Production $\quad 81$ and b) Potential $\mathrm{CH}_{4}$ Consumption, with depth

3.30 Potential $\mathrm{CH}_{4}$ Production vs. Consumption 8.3

3.31 Potential $\mathrm{CH}_{4}$ Production and Consumption vs. Organic Matter Content 8.3

4.1 Comparison of Mean $\mathrm{CH}_{4}$ Fluxes from Wetlands in the BORLAS Northern $\quad 87$ Study Area, for the period from May 15 to September 15, 1994

4.2 Total Annual $\mathrm{CH}_{4}$ Emissions from a) Open Water Sites and 88 b) Vegetated Sites

4.3 Ratio of Standard Error to Mean Flux for different sample sizes of randomly selected a) Bubble Flux and b) Floating Chamber Flux data

4.4 Seasonal $\mathrm{CH}_{4}$ Flux from Tower vs. a) Net Flux from Bubble lraps and Floating Chambers and b) Floating Chamber Measurements alone

4.5 Comparison of $\mathrm{CH}_{4}$ Flux Measured from Tower vs. a) Floating Chamber 98 Measurements and b) Bubble Flux Measurements from this study

4.6 Continuous $\mathrm{CH}_{4}$ Flux from Tower by Wind Direction: a) Flux and 101 b) $\%$ Contribution to Total Flux

4.7 Diel Variation from Continuous Tower $\mathrm{CH}_{4}$ Data $\quad 102$

4.8 Bubbling Rate vs. $\mathrm{CH}_{4}$ Concentration at a) Open Water and $\quad 113$ b) Vegetated Sites

4.9 Water Column Profiles of $\mathrm{O}_{2}$ and Temperature from the Beaver Pond, Late $\quad 122$ August, 1994

4.10 Methane Dynamics in a Northern Boreal Beaver Pond at a) open water sites and $b$ ) sites vegetated with emergent aquatic vegetation 


\section{Chapter 1: Introduction}

\subsection{Introduction}

Beiver ponds are a small but important component of northern wetland ecosystems. They have been found to be relatively high emitters of methane $\left(\mathrm{CH}_{4}\right)$, an important greenhouse gas, compared to other types of wetlands (Fig. 1.1), but they have been neglected in most global and regional greenhouse gas budgets. Determining the net $C H_{4}$ flux and its variability, combined with knowledge about the areal coverage of beaver ponds, will improve understanding of the boreal $\mathrm{CH}_{4}$ budget. This study, part of the Boreal Forest Ecosystem-Atmosphere Study (BOREAS), measured and explains the $\mathrm{CH}_{4}$ flux from a northern boreal beaver pond.

\subsection{Aimospheric Methane}

Methane is the most abundant organic gas in Earth's atmosphere, playing important roles in both radiative climatology, and tropospheric and stratospheric chemistry (Cicerone and Oremland, 1988). Although $\mathrm{CH}_{4}$ is 150-times less abundant in the atmosphere than $\mathrm{CO}_{2}$, on a molar basis it is 21 -times more effective at absorbing longwave radiation. Therefore $\mathrm{CH}_{4}$ is projected to contribute approximately 15 to 19\% of total greenhouse warming (Rodhe, 1990; Slanina and Warneck, 1994).

The concentration of atmospheric $\mathrm{CH}_{4}$ was relatively constant between 3,000 and 200 years ago, but it has doubled in the last 200 years, from 800 ppbv (parts per billion by volume) to over $1700 \mathrm{ppbv}$ (Cicerone and Oremland, 1988). The rate of 


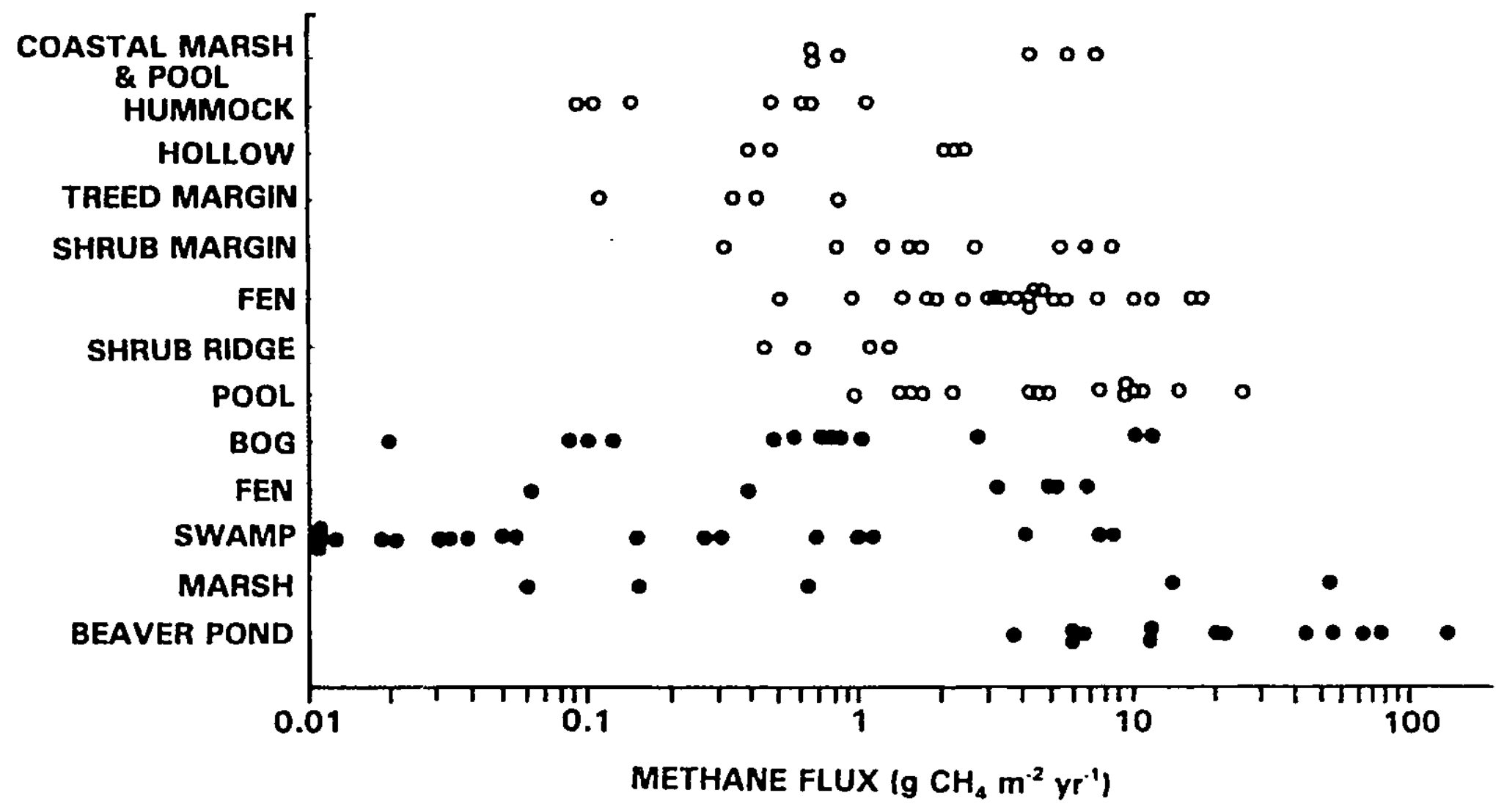

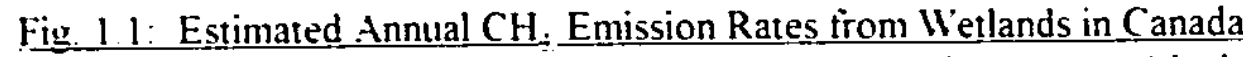
based on broad ecological grouping for subarctic (open circle) and boreal-temperate (shaded circle) regions

From .lloore and Roulet. 1995 
increase peaked at approximately $1 \%$ per year over the last decade, but this rate of increase has declined to $0.7 \%$ per year (Steele et al., 1992; Matthews, 1994).

The increase in atmospheric $\mathrm{CH}_{4}$ may be due to an increase in sources, a decrease in sinks, or both (Moore, 1988). Sinks of $\mathrm{CH}_{4}$ include oxidation by $\mathrm{OH}$ radicals in the troposphere (Cicerone and Oremland, 1988) and uptake by soils (Crill, 1991). Atmospheric $\delta^{1.3} \mathrm{C}$ evidence indicates that the largest component of the observed increase has been an increase in $\mathrm{CH}_{4}$ sources (Cicerone and Oremland, 1988).

\subsection{Sources of Methane}

The atmospheric $\mathrm{CH}_{4}$ budget is given in Table 1. The total of $\mathrm{CH}_{4}$ sources to the atmosphere is estimated to be $500 \mathrm{Tg}^{-1}\left(1 \mathrm{Tg}=10^{12} \mathrm{~g}\right)$ (Matthews, 1994). Natural wetlands are the largest single contributor to the atmospheric burden.

Seasonal and latitudinal differences in atmospheric $\mathrm{CH}_{4}$ concentrations indicate a strong source in the northern hemisphere. The world's largest wetland areas are located between $50^{\circ}$ and $70^{\circ} \mathrm{N}$ (Aselmann and Crutzen, 1989; Fung et al., 1991), which is the same region predicted to undergo the greatest climate changes from most general circulation model estimates of doubled atmospheric $\mathrm{CO}_{2}$ concentrations. In order to predict how wetland $\mathrm{CH}_{4}$ sources may change in a warmer global climate, recent studies have focused on determining controls of $\mathrm{CH}_{4}$ emissions from wetlands under present conditions. 
Table 1. I: Atmospleric CH_ Budget (aller Mathews_ 1994)

\begin{tabular}{|l|c|}
\cline { 2 - 2 } \multicolumn{1}{l|}{} & $\left(1 \mathrm{I}_{1}\left(1 \mathrm{~g}=10^{12} \mathrm{~g}\right)\right.$ \\
\hline Atmospheric Burden & $4000-4800$ \\
\hline Annual Increase & $40-45$ \\
\hline Annual Sources: & 500 \\
\hline 1. Fossil fucl: & \\
\hline \multicolumn{1}{|c|}{ Coal mining } & 35 \\
\hline$\quad$ Natural gas & 80 \\
\hline 2. Biomass burning & 55 \\
\hline 3. Natural wetlands & \\
\hline$\quad$ Northern & 35 \\
\hline$\quad$ Tropical & 80 \\
\hline 4. Rice Cultivation & 75 \\
\hline 5. Animals (mainly domestic ruminants) & 80 \\
\hline 6. Termites & 20 \\
\hline 7. Oceans & 10 \\
\hline 8. Landfills & 25 \\
\hline 9. Methane hydrate releases & 5 \\
\hline 10. Wastewater treatment and animal waste & 40 \\
\hline Annual Sinks & \\
\hline 1. OH destruction & 450 \\
\hline 2. Soil absorption & 10 \\
\hline
\end{tabular}

\subsection{Processes Affecting Methane Emissions from Freshwater Wetlands}

$\mathrm{CH}_{4}$ flux from wetlands is the result of production, consumption and transport processes. $\mathrm{CH}_{4}$ is produced by archaeobacteria during decomposition of organic matter under anaerobic conditions. These bacteria (termed methanogens) are dependent on other anaerobic bacteria to supply them with substrates, which include gaseous hydrogen, carbon dioxide, formate, acetic acid, and one-carbon compounds (Svensson and Sundh, 1992; Knowles, 1993). Archaeobacteria can tolerate some oxygen exposure, but require strongly reduced conditions ( $E h<-300 \mathrm{mV}$ ) for growth 
(Knowles, 1993). Methanogens inhabit acid environments typical of most anacrobic soils (pll 6 to 8). Temperature optima have been found to be between $25^{\circ}$ and $30^{\circ} \mathrm{C}$, with low temperatures $\left(0\right.$ to $\left.10^{\circ} \mathrm{C}\right)$ permitting little production activity, even in arctic peat soils (Dunfield et al., 1993) where adaptation to low temperatures might be expected.

The two main pathways for methane production in freshwater ecosystems are acetate fermentation and $\mathrm{CO}_{2}$ reduction (Whiticar et al., 1986). $\mathrm{CH}_{4}$ can be derived from a methyl group of any substrate, but since acetate is most common, this pathway is termed acetate fermentation. Acetate fermentation accounts for approximately $70 \%$ of all $\mathrm{CH}_{4}$ produced in freshwater ecosystems (Whiticar et al., 1986). The other major production pathway is $\mathrm{CO}_{2}$ reduction, in which hydrogen is used as an electron source. These two pathways result in different isotopic compositions of the produced $\mathrm{CH}_{4}$. Methane produced by acetate fermentation is generally enriched in ${ }^{13} \mathrm{C}$ and depleted in $\mathrm{D}$ (deuterium) compared to that produced by $\mathrm{CO}_{2}$ reduction (Happell et al., 1993).

$\mathrm{CH}_{4}$ is consumed by methanotrophs which are obligate aerobes. Consumption is dependent on oxygen for the first step of methane oxidation, although some methanotrophs may prefer sub-atmospheric $\mathrm{O}_{2}$ concentrations (King, 1992). Certain anaerobic methanotrophs have been identified, but their importance in wetland environments has not been studied (Whiticar and Faber, 1985). Optimum temperatures for aerobic $\mathrm{CH}_{4}$ consumption range from 20 through $25^{\circ} \mathrm{C}$, although substantial activities have been observed at temperatures as low as 0 to $5^{\circ} \mathrm{C}$ (Dunfield et al., 1993). Therefore, $\mathrm{CH}_{4}$ oxidation can occur at lower temperatures than production. During oxidation, methanotrophs preferentially consume the lighter 
isotopes of both carbon and hydrogen, leaving residual $\left(\mathrm{H}_{4}\right.$ enriched in "' $\mathrm{C}$ and $\mathrm{D}$ (Coleman et al., 1981; Chanton ct al., 1992).

$\mathrm{CH}_{4}$ can be transported from wetland sediments to the atmosphere by three mechanisms: diffusion, gas bubble cbullition, and plant transport. Diftusion is a relatively slow transport mechanism, controlled by the $\mathrm{CH}_{4}$ concentration gradient and the diffusivity of the medium. Diffusing $\mathrm{CH}_{4}$ will be subject to oxidation by methanotrophs if it passes through aerobic layers.

Ebullition (bubbling) has been observed in flooded wetlands, and is a much more rapid transport process than diffusion, and more $\mathrm{CH}_{4}$ bypasses zones of oxidation (Martens and Klump, 1980; Martens et al., 1986). Gas bubbles form as vertical columns in sediments where porewater $\mathrm{CH}_{4}$ reaches supersaturation. When bubble pressure exceeds pressures exerted by the overlying materials and the atmosphere, bubbles will be released from storage in the sediments to the atmosphere. Ebullition events have been found to be correlated with water table fluctuations (Windsor et al., 1992) and atmospheric pressure fluctuations (Mattson and Likens, 1990), where negative pressure changes stimulate bubble release.

Vascular plants have been identified as being important in the transport of $\mathrm{CH}_{4}$ but their role is not well understood (Dacey and Klug, 1979; Whiting and Chanton. 1992). Plants may enhance the flux of $\mathrm{CH}_{4}$ by providing substrate for the production of $\mathrm{CH}_{4}$ in the root zone, or by acting as conduits for atmospheric exchange (Dacey, 1980). They may attenuate $\mathrm{CH}_{4}$ flux by transporting atmospheric oxygen to the roots, promoting $\mathrm{CH}_{4}$ oxidation. The overall effect of plants on $\mathrm{CH}_{4}$ flux is considered to be positive (Epp and Chanton, 1993). 


\subsection{Controls of Methane Flux from Wetlands}

Several parameters have been identified in laboratory and field experiments as important indicators of $\mathrm{CH}_{4}$ flux. Formulating strong predictive relationships has largely been unsuccessful, however, since many of these variables are correlated with both production and oxidation processes, but in different ways. Furthermore, many environmental variables affect $\mathrm{CH}_{4}$ flux from wetlands, and they act at different scales. Factors affecting $\mathrm{CH}_{4}$ availability may vary over microscales and very short times, while factors controlling $\mathrm{CH}_{4}$ transport influence larger areas over longer time periods. Field methods measure fluxes over scales that incorporate many scale-dependent processes, therefore fluxes are typically variable, with coefficients of variation (standard deviation:mean) commonly ranging from 30 to $100 \%$ within a site (e.g. Moore and Roulet, 1991).

The most successful variables explaining flux are those which integrate environmental factors. Water table position, a surrogate for aerobic/anaerobic status, has been found to be the strongest indicator of $\mathrm{CH}_{4}$ flux. When the water table is below the wetland surface, an aerobic zone forms, and methanotrophs may deplete the $\mathrm{CH}_{4}$ reservoir and attenuate flux. When the water table is at or above the surface, anaerobic conditions dominate, and less $\mathrm{CH}_{4}$ is oxidized. While laboratory experiments have successfully used water table position to predict flux at a single site (Moore and Knowles, 1989; Moore and Roulet, 1993), this variable has been successfully used in the field only to explain differences in fluxes between sites having different water table positions and therefore different degrees of anaerobism (Roulet et 
al., 1992; Bubier et al., 1993; Dise et al., 1993). The inability to show clear relationships between water table position and llux at a given site is likely due to coincident changes in temperature, plant activities, or pressure causing episodic release of $\mathrm{CH}_{4}$ stored in porewaters.

Laboratory experiments have revealed the importance of temperature in controlling rates of $\mathrm{CH}_{4}$ production and consumption (e.g. Svensson, 1984; Duntield et al., 1993). On a few occasions, significant correlations between CH., emissions and temperature have been observed in the field (e.g. Crill et al., 1988; Bubier et al., 1995a). Other studies have found that temperature only explains fluxes once the primary variable of sustained water table position is satisfied (Roulet et al., 1992; Disc et al., 1993), or that it does little to improve the predictive capability of the water table position vs. flux relationship (Moore et al., 1990; Dise et al., 1993). While $\mathrm{CH}_{4}$ lluxes are often positively correlated with temperature and water table position, these relationships are generally weak and do not hold across ecosystem types.

A strong predictive relationship between temperature at the mean position of the water table and $\mathrm{CH}_{4}$ flux has recently been demonstrated for northern boreal wetlands (Bubier et al., 1995a). This variable integrates information about moisture and temperature, and may therefore be a useful indicator of flux in other regions. Macrophyte and bryophyte communities have also been used successfully to predict $\mathrm{CH}_{4}$ flux across wetland types since plants respond to a host of factors and therefore represent good environmental integrators (Bubier et al., 1995a, 1995b). 
In addition, plant communities can be mapped more easily than water table or soil temperature, and therefore hold promise as tools for extrapolation of $\mathrm{CH}_{4}$ fluxes.

Substrate characteristics (such as pH and nutritional status) have been found to control methane production and consumption rates in some laboratory experiments (Knowles, 1993). Field studies indicate that emissions are lowest from nutrient-poor bogs, and increase in order to fens, swamps and marshes (Aselmann and Crutzen, 1989). These wetlands categories have been used to extrapolate regional and global wetland $\mathrm{CH}_{4}$ emissions using representative $\mathrm{CH}_{4}$ fluxes and areal coverage estimates (Bartlett and Harriss, 1993; Matthews, 1994).

\subsection{Beaver Ponds as a Source of Atmospheric Methane}

Very few studies of $\mathrm{CH}_{4}$ emissions from wetlands have included beaver ponds. Of these, only one investigated diffusive and bubble fluxes separately (Weyhenmeyer, 1992). Boreal wetland $\mathrm{CH}_{4}$ emissions have ranged from 0.1 to $65.7 \mathrm{~g} \mathrm{CH}_{4} \mathrm{~m}^{-2} \mathrm{y}^{-1}$, with most $<10 \mathrm{~g} \mathrm{CH}_{4} \mathrm{~m}^{-2} \mathrm{y}^{-1}$ (Matthews, 1994), while $\mathrm{CH}_{4}$ emissions from beaver ponds have ranged from 5.9 (Ford and Naiman, 1988) to 76.2 (Vitt et al., 1990) $\mathrm{g} \mathrm{CH}_{4}$ $\mathrm{m}^{-2} \mathrm{y}^{-1}$. Roulet et al. (1992) found that even though beaver ponds comprised $7 \%$ of a low boreal wetland area, they contributed approximately $32 \%$ of the annual $\mathrm{CH}_{4}$ flux. However, beaver ponds have not been used in the global $\mathrm{CH}_{4}$ emission estimates (Matthews, 1994). 
Beaver ponds may contribute signilicantly to the wetland $\left({ }^{2} H_{1}\right.$ budget lor thee reasons: (1) beavers alter stream ecosystems in a manner that promotes conditions for $\mathrm{CH}_{4}$ production; (2) these ecosystems receive inputs of carbon-rich materials, increasing the availability of substrate for methanogenesis; and (.3) the areal extent of beaver ponds appears to be increasing in response to declining population pressure from humans and other predators.

Beavers (('astor canculensis) dam rivers and streams to increase the area of aquatic habitat in order to provide protection from predators and to increase their food supply (Naiman et al., 1988). Impoundment reduces flow velocity, hence suspended sediments and organic matter tend to settle in ponds. The combination of low flow and a high oxygen demand of the decomposing organic sediments results in the formation of anaerobic conditions. In addition to organic matter inputs from upstream and riparian zones, individual beavers can import up to $I$ tonne of organic matter into a pond each year (Naiman et al., 1986). When previous wetland or peatland ecosystems are flooded by beavers, the peat profiles can themselves contribute to the supply of organic matter for methanogenesis. Beaver ponds have been found to have greater standing stocks and greater inputs and outputs of carbon per unit length of stream, compared to streams without beavers (Naiman et al., 1986, 1988). However, little of this material is transported downstream; carbon outputs occur instead as respiration and methane evasion (Naiman et al., 1988).

The beaver was made nearly extinct by the turn of the last century, when hunting and trapping removed large numbers of beaver every year (Naiman et al., 
1988). Since that time, demand for pelts has decreased, laws have been imposed to regulate trapping, and beaver populations have made a strong recovery in North America. Significant, but poorly quantified, populations inhabit Eurasia and the former Sovict Union, although populations are still low in Europe (Nisbet, 1989). Estimates of current beaver populations in North America are in the range of 6 to 12 million (Naiman et al., 1988), which is about $10 \%$ of the pre-European settlement population. Population densities in favourable habitats are 0.4 to 0.8 colonies $\mathrm{km}^{-2}$ ( 1 colony generally consisting of 4 to 8 individuals) but have been found to be as great as 3 colonies $\mathrm{km}^{-2}$ (Naiman et al., 1986).

Bcaver ponds are typically inhabited for 5 to 20 years (Nisbet, 1989), but changes to the biogeochemistry of stream ecosystems may persist for decades to centuries after occupation (Naiman et al., 1988). Beavers tend to select optimal sites for ponds first, then impound marginal areas as resources become depleted. Ponds that are impounded first have greater longevity than ponds built on less ideal sites (Naiman et al., 1988).

\subsection{Conceptual Model of Methane Dynamics in Beaver Ponds}

As indicated above, the few studies that have examined the flux of $\mathrm{CH}_{4}$ from beaver ponds have found them to be relatively high emitters compared to other wetland types. The reasons for these high fluxes are poorly understood. In general, high organic inputs to ponds combined with sustained anaerobism caused by inundation are believed to explain the high emissions. 
A conceptual model of a beaver pond and the factors that relate to the flux of $\mathrm{CH}_{4}$ are shown in Fig. 1.2. A beaver pond can viewed as a system, with $\mathrm{CH}_{4}$ traveling across several interfaces. Controls of the flux operate at two levels: controls on $\mathrm{CH}_{4}$ production and consumption processes in the sediments, and controls on the transport processes which in turn may influence further oxidation.

$\mathrm{CH}_{4}$ is produced in the sediments of a beaver pond at rates controlled by substrate availability and temperature. Since the sediments are always saturated, production is likely to be more closely related to temperature variations than in other wetland ecosystems with variable moisture conditions. Greater sediment heat fluxes and higher maximum temperatures have been observed in beaver ponds compared to other wetland types (Roulet et al., 1992; Naiman et al., 1994), therefore the $\mathrm{CH}_{4}$ production zone may extend deeper in pond sediments than in other wetlands.

Once produced, $\mathrm{CH}_{4}$ is either stored in the sediments, oxidized by methanotrophs, or transported to the atmosphere via ebullition, diffusion, and/or plants. Sedimentary $\mathrm{CH}_{4}$ oxidation may only be a small component of the budget, because the sediments are consistently inundated and because decomposition processes compete with methanotrophs for available oxygen. The zone of greatest activity for methanotrophs will be close to the anaerobic-aerobic interface, where both $\mathrm{CH}_{4}$ and $\mathrm{O}_{2}$ are available in significant quantities (Knowles, 1993). Algal or cyanobacterial mats inhabiting the surface of the pond sediments may provide $\mathrm{O}_{2}$ for $\mathrm{CH}_{4}$ oxidation during daylight hours (King, 1990). 

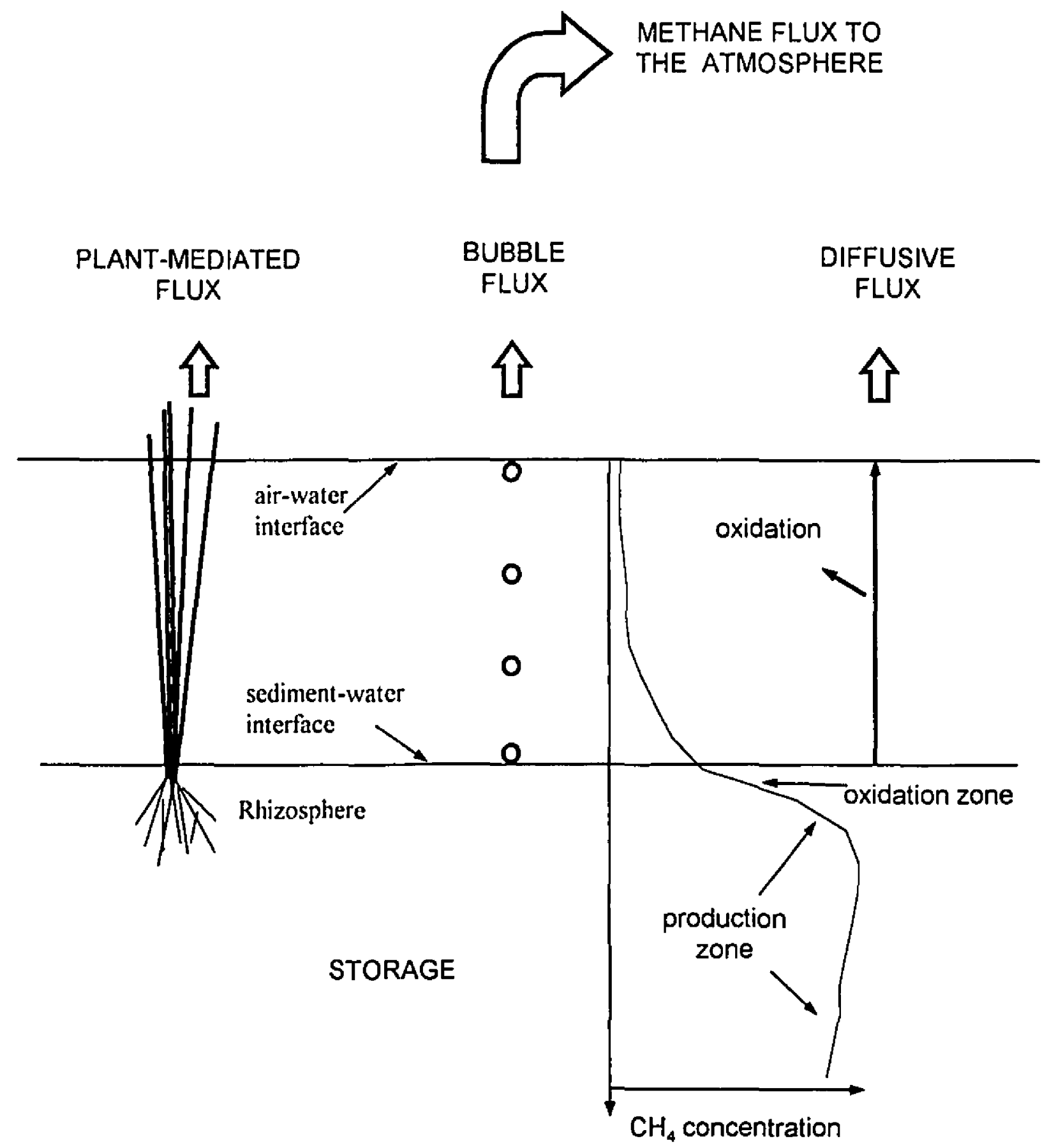

Fig. 1.2: Conceptual Model of Methane Dynamics in a Beaver Pond Curved line is a theoretical profile of $\mathrm{CH}_{4}$ in the sediments and in the water column 
If rates of $\mathrm{CH}_{4}$ production in ponds are greater than removal rates by diriusion, large amounts of gaseous and dissolved $\mathrm{CH}_{4}$ can potentially be stored in the sediments. The $\mathrm{CH}_{4}$ storage reservoir in beaver ponds is likely large, because the sediments consist of high-porosity flocculent organics deposited in a slow-llowing hydrological environment. Bubble fluxes will occur at a rate controlled by the excess of $\mathrm{CH}_{4}$ production over oxidation, storage, and the other transport mechanisms. The magnitude of these fluxes may be related to changes in pressure (water table position and atmospheric pressure) and the current size of the sediment $\mathrm{CH}_{4}$ reservoir.

Emissions from vascular plants are likely greater than diffuse emissions from equivalent open water areas because plants may provide a conduit that bypasses the oxidation layer. Certain plant species may actively ventilate the sediments surrounding their roots, resulting in lower porewater $\mathrm{CH}_{4}$ concentrations and therefore lower bubble emissions. Higher production rates may be associated with root exudates and therefore enhance $\mathrm{CH}_{4}$ fluxes, or conversely, oxidation associated with $\mathrm{O}_{2}$ diffusion across the root-sediment interface may fuel higher rates of $\mathrm{CH}_{4}$ consumption and result in lower $\mathrm{CH}_{4}$ emissions from vegetated areas.

\subsection{Study Objectives}

The specific objectives of the research presented in this thesis are to determine: (1) the relative contributions of $\mathrm{CH}_{4}$ production, consumption and transport processes to the flux of $\mathrm{CH}_{4}$ from a boreal forest beaver pond; (2) how these processes vary within the pond and over an emission season; and (3) the relationship among these processes and environmental variables. 
Specifically, four hypotheses were tested from May through mid-September, 1994, at a single beaver pond near Thompson, Manitoba:

1. The annual flux of $\mathrm{CH}_{4}$ from the beaver pond to the atmosphere is relatively high compared to values reported in the literature for other wetlands because the hydrological and thermal regimes in beaver ponds maximize $\mathrm{CH}_{4}$ production and minimize $\mathrm{CH}_{4}$ oxidation.

2. Oxidation of $\mathrm{CH}_{4}$ reduces the overall flux little, because:

2.1 ebullition and plant transport mechanisms dominate and bypass the main zone of oxidation

2.2 oxidation of $\mathrm{CH}_{4}$ at the sediment-water interface is small because the thickness of the zone for potential oxidation is small, and

2.3 little oxidation occurs in open water.

3. As a consequence of hypothesis 2.1 , the loss of $\mathrm{CH}_{4}$ from the sediments relates to negative changes in atmospheric pressure and water table position

4. The flux from plants is greater than the flux from open water areas since plant transport bypasses $\mathrm{CH}_{4}$ oxidation and $\mathrm{CH}_{4}$ production is greater in vegetated areas.

The results from this thesis represent a significant advancement in the processlevel understanding of $\mathrm{CH}_{4}$ emissions from beaver ponds. The following chapters describe the field programme, BOREAS and the methods and materials (Chapter 2), and the results obtained (Chapter 3). The results encompass information about $\mathrm{CH}_{4}$ 
processes, storage and fluxes over all interfaces and from different areas of the pond. They indicate that the flux of $\mathrm{Cl}_{4}$ from the beaver pond is high and variable, but that these variations relate to environmental lactors and site differences.

These lines of evidence are pursued in Chapter 4 . The magritude, variability and contributions of the various transport processes to the total $\mathrm{CH}_{4}$ llux from this beaver pond are described. A detailed error analysis is performed and suggestions are made for future sampling programmes. Comparisons with the flux of $\mathrm{CH}$, from other wetlands in the same area indicate that beaver ponds are a signilicant regional source which should not be neglected in greenhouse gas budgets. 


\section{Chapter 2: Study Site and Methodology}

\subsection{The Boreal Forest Heosystem-Atmosphere Study}

The Boreal Jiorest Ecosystem-Atmosphere Study (BOREAS) is an international collaborative special project designed to clarify the role of the boreal forest biome in the global climate system and carbon budget. In particular, it is aimed at improving our understanding of the processes which govern the exchanges of energy, water, carbon dioxide, and trace gases between the boreal forest and the atmosphere, and to develop and validate remote sensing algorithms to transfer our understanding of these processes from local to regional scales. Research was undertaken in and between two $600 \mathrm{~km}^{2}$ study sites in central Canada to represent the north-south ecological gradient of temperature and moisture (Fig. 2.1). The southern study area (SSA), near Prince Albert, Saskatchewan lies along the sourthern edge of the boreal forest biome where ecosystem processes are generally moisture-limited during the summer. The northern study area (NSA), near Thompson, Manitoba, is representative of the northern portion of the boreal forest, where ecosystem processes are generally temperature-limited.

BOREAS includes research from a wide range of scientific fields, i.e. terrestrial ecology, snow hydrology, land surface climatology, boundary layer meteorology, trace gas biogeochenistry and remote sensing science. Over 80 research teams are involved, including 10 teams from Canadian universities. BOREAS is scheduled for a period of four years (1992 - 1996). The first year, 1992-93, was used for planning, site selection. preliminary studies and testing of equipment for the intensive field campaign in 1994. 


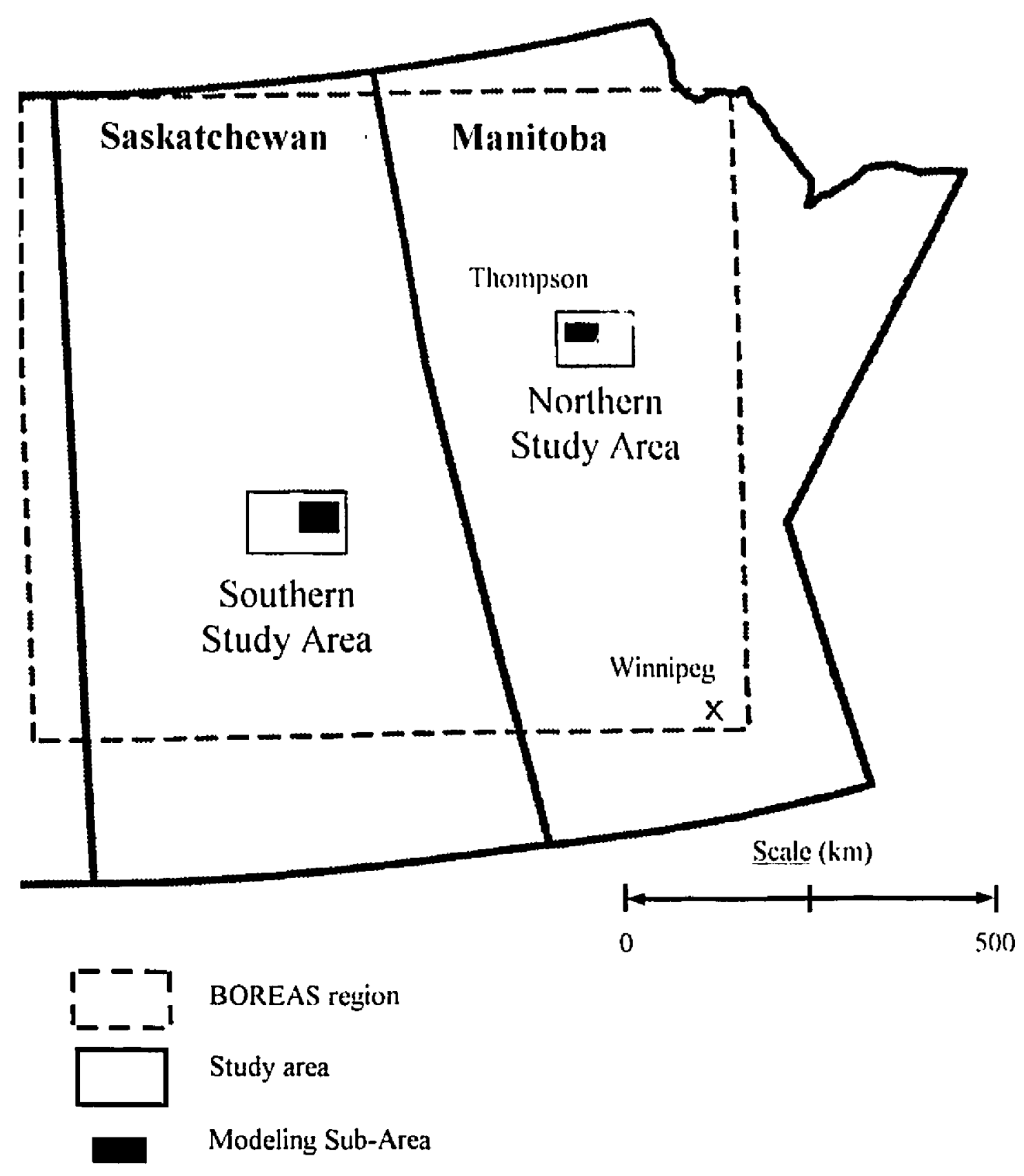

Fig. 2.1: BOREAS Study Areas

Research for this study was undertaken at the Northern Study Arca near Thompson, Manitoba 


\subsection{Sludy Site}

The field work for this study was conducted as part of a BOREAS Trace Gas Biogeochemistry (TGB) investigations at the northern study area (NSA). A single beaver pond, located $13 \mathrm{~km}$ west of 'I'hompson, approximately $300 \mathrm{~m}$ south of Highway $391\left(55^{\circ} 55^{\prime} \mathrm{N}, 98^{\circ} 01^{\prime} \mathrm{W}\right.$; military grid reference 614887$)$, was selected for study (Fig. 2.2). It is the last, but onc, in a series of ponds in a drainage basin that is about $15 \mathrm{~km}$ in length and $3-5 \mathrm{~km}$ in width. The pond covers $5 \mathrm{ha}$, and has two dams: one on the northern outflow, and one on the eastern outflow. The dam on the primary (east) outflow is approximately $60 \mathrm{~m}$ long by $3 \mathrm{~m}$ wide. The pond receives waters from many small, seasonal streams at the south end.

The age of the pond is unknown but it is inhabited by a family of 3 or more beavers. It also provided habitat for a family of wood ducks and migratory birds in the spring and fall, 1994. Prior to impoundment by beavers the area was a peatland. The sediments comprise a thick layer $(0.05$ to $0.2 \mathrm{~m})$ of gyttja, overlying peat sediments $(0.1$ to $1.0 \mathrm{~m})$ over silt and sands. Clay was observed in one area of the pond at 0.7 to $1.0 \mathrm{~m}$ depth.

The maximum pond depth is approximately $2.2 \mathrm{~m}$ to the west of the main dam, but most of the pond is 0.5 to $1.0 \mathrm{~m}$ deep. About $75 \%(3.75 \mathrm{ha})$ of the pond is covered with aquatic emergent vegetation, primarily sedges (Carcx.sp.), some of which grows on mats floating on the pond surface. Submergent aquatic vegetation (primarily (Utricularia sp.) was present in most areas of the pond. A detailed list of the vegetation is provided in Table 2.1 . 


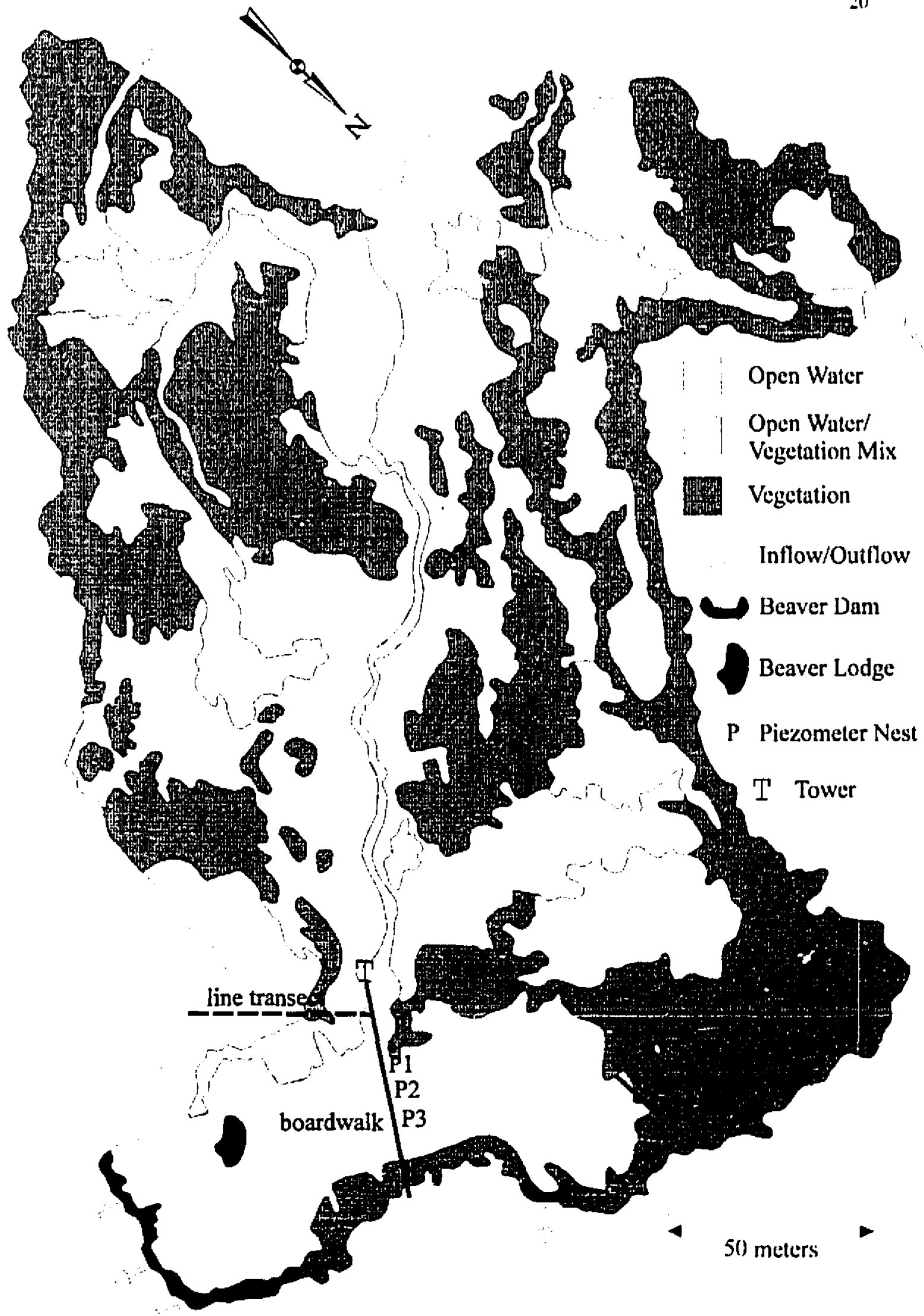

Fig.2.2: Map of the Beaver Pond with Sampling Locations 
Table 2.1 L ist of Vascular Plant Species at the Beaver Pond dominant species are marked by an asterisk (*)

$$
\begin{aligned}
& \text { Emergent Aquatic Vegetation: } \\
& \text { * (arex alymatilis } \\
& \text { ('. limosist } \\
& \text { ('. dicandra } \\
& \text { (. rosirnara }
\end{aligned}
$$

Submergent Aquatic Vegetation:

Utricularia vilgaris

1). cornata

U. imermedia

\subsection{Field Methods}

Field work was conducted between May 1 and Sept. 15, 1994. The field measurements comprised determining the flux of $\mathrm{CH}_{4}$ at the water-air interface as diffusion and ebullition; the flux of $\mathrm{CH}_{4}$ at the sediment-water interface; the dynamics of $\mathrm{CH}_{4}$ storage in the sediments and in the open water; and the sampling of bubbles and stored gas for isotopic determination. The beaver pond (Fig. 2.2) was outfitted with a floating boardwalk and a platform on which a $1.5 \mathrm{~m}$ tower was erected for measurement of environmental variables and the flux of heat, water, $\mathrm{CO}_{2}$ and $\mathrm{CH}_{4}$ by micrometeorological techniques. 


\subsubsection{Floating Chamber Flux Measurements}

Static floating chambers were employed to measure diftusion of $\mathrm{CH}_{4}$ across the water-air interface approximately every third day during the field season using methods

outlined in Moore and Roulet (1991). The chambers were made of $18 \mathrm{~L}$ polycarbonate bottles from which the bases had been removed, and were covered with aluminum foil to reduce heating. A styrofoam float was aftixed $2 \mathrm{~cm}$ above the base of the chamber. The necks were sealed with a rubber stopper containing a glass tube to which $4 \mathrm{~m}$ of tygon tubing was attached. Samples were obtained from the end of the tubing through a stopcock after pumping several times with a $60 \mathrm{cc}$ syringe to ensure the air was mixed within the chamber.

Most fluxes were obtained adjacent to the boardwalk. Ten chambers were used on each sampling date; of these, generally 6 measured fluxes from open water sites, 2 from sites colonized by ('arex sp., and 2 from other vegetation types. Depth of site, vegetation characteristics and time of day were recorded. Chambers and tubing were flushed with ambient air, then chambers were gently placed on the pond surface. One sample was obtained every five minutes for 20 minutes, so that each flux measurement was based on four data points. The change in $\mathrm{CH}_{4}$ concentration over time in the chambers was used to determine $\mathrm{CH}_{4}$ flux (Eq. I). If the rise in concentration was not linear $\left(r^{2}>0.9\right.$ for $\left.n=4\right)$ then the flux was rejected.

Two diel experiments were performed to determine if fluxes varied systematically with the time of day. On these occasions, 6 fluxes were obtained from various sites every 4 hours for 24 hours. 


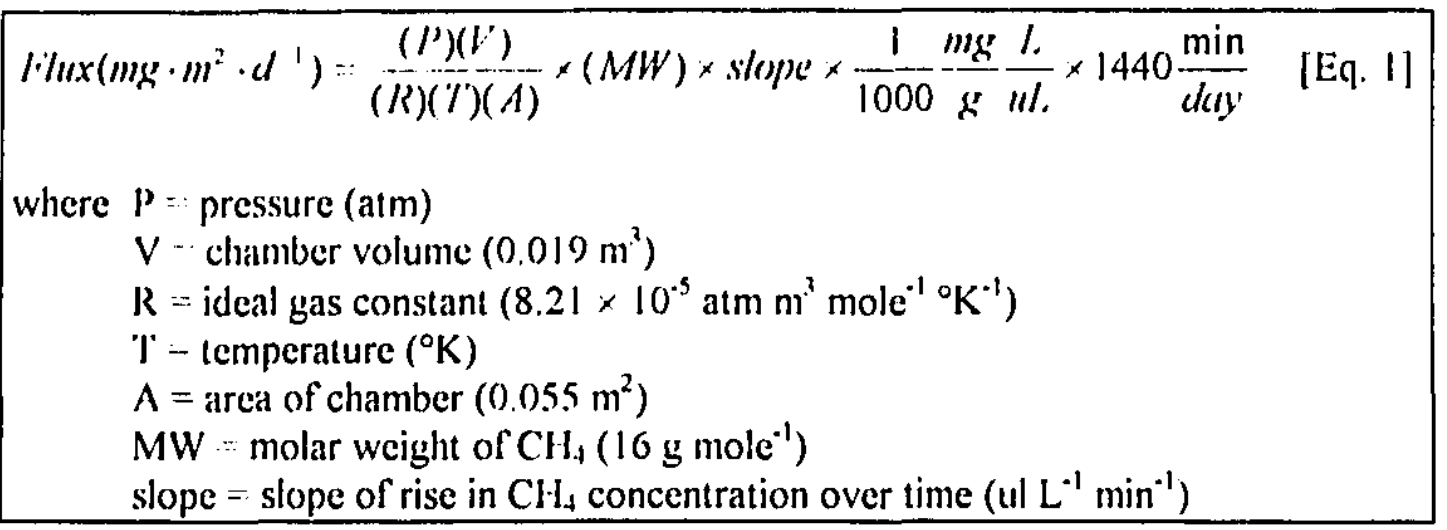

\subsection{2_Bubble Flux Measurements}

Bubble fluxes were measured using inverted funnels along two transects (Fig.

2.2). The line transect comprised 12-14 funnels and extended east from the boardwalk across a vegetated area and deeper open water sites to the pond margin. The beam transect was located west of the boardwalk, extending from a floating mat toward the pond margin, and comprised an additional 14-18 funnels. The beam transect was primarily vegetated by emergent macrophytes such as (arex sp. but also crossed several open water channels which flowed between the vegetation.

Thirty-cm diameter inverted funnels were fitted with clear graduated cylinders and a stopper through which bubbles were sampled. Small floats were attached to the funnels to keep them floating at the water-air interface, and the funnels were secured to the line or beam transect by small pieces of rope. Funnel sites were classified as either vegetated or open-water. Vegetated sites contained both emergent and submergent vegetation, and funnels were not placed directly over but rather between the emergent vegetation. Open water sites almost always contained some submergent vegetation. 
Bubbles that accumulated in the funnels were sampled by boat, usually within two days. Bubble volume was measured by carefully withdrawing the bubbles into syringes. Flux was calculated (Eq. 3) from the volume of bubbles that had accumulated over the time between measurements, and the concentration of $\mathrm{Cl}_{4}$ in the bubbles.

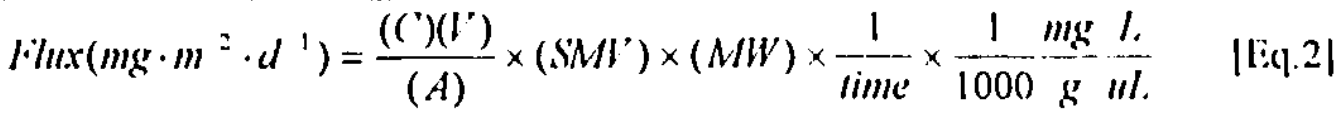

$$
\begin{aligned}
& \text { where } \mathrm{C}=\text { bubble } \mathrm{CH}_{4} \text { concentration }\left(\mathrm{uL} \mathrm{L}^{-1}\right) \\
& \mathrm{V}=\text { volume of accumulated bubbles }(\mathrm{L}) \\
& A=\text { funnel area }\left(0.073 \mathrm{~m}^{2}\right) \\
& \text { SMV = standard molar volume of gas }\left(1 / 22.4 \text { mole } L^{-1}\right) \\
& \mathrm{MW}=\text { molar weight of } \mathrm{CH}_{4}\left(16 \mathrm{~g} \mathrm{~mole}^{-1}\right)
\end{aligned}
$$

\subsubsection{Porewater $\mathrm{CH}_{4}$ Storage}

Porewater $\mathrm{CH}_{4}$ concentrations were used to calculate storage of $\mathrm{CH}_{4}$ and changes in storage during the field season. $\mathrm{CH}_{4}$ concentrations in sediments were determined approximately every third day at 3 sites along the boardwalk from 5 piezometers at each site. The 3 sites comprised one shallow water $(\approx 0.2 \mathrm{~m})$ vegetated site, one intermediate site $(\approx 0.7 \mathrm{~m})$ with submergent aquatic vegetation, and one deep water site $(\approx 2.0 \mathrm{~m})$ with no observable vegetation. The depths of the piezometers at each site were $10,30,50,70$, and $100 \mathrm{~cm}$ below the sediment-water interface.

Piezometers were constructed from $1.75 \mathrm{~cm}$ PVC pipe, were perforated at the desired sampling depth, and fitted with tygon tubing through which samples were 
drawn. During sampling, the tubing was flushed and $30 \mathrm{ml}$ samples were slowly withdrawn to prevent bubbling and degassing. Storage was calculated by integrating the profiles of dissolved $\mathrm{CH}$, concentrations and assuming a constant porosity of 0.8 .

\subsubsection{Sediment-Water Interface $\mathrm{CH}_{4}$ Profiles}

High resolution profiles of $\mathrm{CH}_{4}$ concentrations at the sediment surface were determined using peepers (Hesslein, 1976). Peepers comprised 51 chambers at $1 \mathrm{~cm}$ intervals which were filled with distilled water in the lab and covered with a semipermeable membrane through which $\mathrm{CH}_{4}$ can diffuse. Peepers were installed across and below the sediment-water interface 2 weeks prior to sampling to permit equilibration with in silu $\mathrm{CH}_{4}$ concentrations. Profiles were used to identify the zones of $\mathrm{CH}_{4}$ production and consumption, and to model the Fickian diffusive flux of $\mathrm{CH}_{4}$ from the sediments (Eq. 3).

$F_{1}=\eta D \frac{\Delta C^{\prime}}{\Delta z}$

where $\eta=$ porosity (assumed 0.8 )

$\mathrm{D}=$ diffusion coefficient $\left(\mathrm{cm}^{2} \mathrm{~s}^{-1}\right)$ which was determined to vary according to temperature (Lerman, 1979) with $r^{2}=0.99$ :

$0.796+\frac{0.0293+T}{0.000325 \times T^{2}} \quad$ where $\mathrm{T}=$ sediment temperature and $\frac{\Delta C^{\prime}}{\Delta z}=$ maximum $\mathrm{CH}_{4}$ concentration gradient below the sediment-water interface 


\section{2 .5 Water Column $\mathrm{CH}_{4}$ Profiles}

Profiles of $\mathrm{CH}_{4}$ in the water column were determined approximately bi-iveckly using a pole secured to stationary posts along the boardivalk. Tygon tubes were attached to the pole to sample water at $0,2,4,6,8,10,20,40,60,80,100$, and 120 $\mathrm{cm}$ above the sediment-water interface. Samples were drawn slowly through the tubing by syringe.

\subsubsection{Surface-Water $\mathrm{CH}_{4}$ Concentrations}

Concentrations of $\mathrm{CH}_{4}$ in surface water were determine? concurrently with about $50 \%$ of the floating chamber fluxes, to be used in a thin-film boundary layer model to calculate the diffusive flux of $\mathrm{CH}_{4}$ from the pond. However, the fluxes derived by this model were an order of magnitude lower than the tower $\mathrm{CH}_{4}$ fluxes ( $P$. Crill and N. Roulet, unpubl. data) and chamber fluxes; therefore the data were not incorporated into the analysis.

\subsubsection{Flux of $\mathrm{CH}_{4}$ across the Sediment-Water Interface}

Benthic chambers were designed to measure the flux of $\mathrm{CH}_{4}$ across the sediment-water interface. Chambers were built from inverted $12 \mathrm{~L}$ tupperware containers (base $26 \mathrm{~cm} \times 38.5 \mathrm{~cm}$ ) and equipped with a pump and hose with which to slowly circulate water within the chambers. Chambers were lowered to the bottom of the pond adjacent to the boardwalk and gently held in place by foot. The pump was started and water was circulated at $1 \mathrm{~L} \mathrm{~min}^{-1}$. Samples were taken through the 
sampling port by syringe every 2 minutes for 10 minutes. $\mathrm{CH}_{4}$ flux was calculated using E\&. 1 modified for the area and volume of these chambers.

Fluxes measured using methyl fluoride (MF) as a $\mathrm{CH}_{4}$ oxidation inhibitor followed the same procedure. Flux was first measured without $\mathrm{MF}$, the chamber was flushed and then replaced. MF was injected into the chamber to a concentration of $1 \%$ MF by volume, and samples were taken as described above. Oxidation was calculated as the difference between the flux measured with MF and those without MF inhibition.

\subsubsection{Environmental Variables}

Environmental variables used in the analysis were measured on the micrometeorological tower at the platform at the end of the boardwalk. Table 2.2 lists these variables and the equipment used.

Table 2.2 Measurement of Environmental Variables

\begin{tabular}{|c|c|c|}
\hline Variable & Equipment & Location \\
\hline Air temperature & thermocouples & $1.5 \mathrm{~m}$ above pond surface \\
\hline Pond temperature & thermocouples & $\begin{array}{l}1,10,20 \text {, and } 30 \mathrm{~cm} \text { below' } \\
\text { pond surface }\end{array}$ \\
\hline Sediment temperature & thermocouples & $\begin{array}{l}0,5,10,20,40,75 \text {, and } 150 \\
\mathrm{~cm} \text { below the sediment-water } \\
\text { interface }\end{array}$ \\
\hline Precipitation & tipping bucket rain gauge & beaver pond and NSA fen \\
\hline Pond stage & float and sensor & \\
\hline $\begin{array}{l}\text { PAR (photosynthetically- } \\
\text { active radiation) }\end{array}$ & PAR sensor & $1.5 \mathrm{~m}$ above pond surface \\
\hline Underwater PAR & PAR sensor & $\begin{array}{l}50 \text { to } 70 \mathrm{~cm} \text { below pond } \\
\text { surface }\end{array}$ \\
\hline Atm:ospheric pressure & barometer & \\
\hline Windspeed & anemometer & $1 \mathrm{~m}$ above pond surface \\
\hline
\end{tabular}


Half-hourly or hourly averages of the variables were stored in a datalogger located at the base of the tower, and daily means were later ealculated for each variable. Daily mean PAR and underwater PAR were calculated using only positive (daytime) values.

\subsection{Laboratory Methods}

The laboratory methods comprised the analysis of $\mathrm{CH}_{4}$ samples, incubation experiments to examine the $\mathrm{CH}_{4}$ production and oxidation potentials of the pond sediments, and analysis for the isotopic composition of carbon and hydrogen in $\mathrm{CHI}_{4}$ stored and emitted from the pond.

\section{$2.3 .1 \mathrm{CH}_{4}$ Analysis}

Analysis for $\mathrm{CH}_{4}$ was determined by gas chromatography within 8 hours of sampling. $\mathrm{CH}_{4}$ in bubbles was determined using a Shimadzu-8A thermal conductivity detector (TCD) equipped with a HeyeSep column and $5 \mathrm{~A}$ molecular sieve, using ultrahigh purity (UHP) He as carrier gas tlowing at $30 \mathrm{ml} \mathrm{min}^{-1}$. The column and detector temperatures were $50^{\circ} \mathrm{C}$ and $130^{\circ} \mathrm{C}$, respectively, and the detector bridge current was $160 \mathrm{~mA}$. All other samples were analysed with a Shimadzu Mini-2 equipped with a flame ionization detector (F1D) and a $1.8 \mathrm{~m}$ Poropak-Q column (50/80 mesh), using UHP $\mathrm{N}_{2}$ as carrier gas flowing at $40 \mathrm{ml} \mathrm{min}{ }^{-1}$. The column and detector temperatures were $45^{\circ} \mathrm{C}$ and $125^{\circ} \mathrm{C}$, respectively. Both machines were also equipped with 1 or 3 $\mathrm{ml}$ sample loops to standardize injections. 
('H. standards of 2.349 and $10200 \mathrm{ppm}$ were run with samples to calibrate concentrations. The FID responded linearly to $\mathrm{CH}_{4}$ concentrations between $0.9 \mathrm{ppm}$ and $10200 \mathrm{ppm}$. The precision of the FID was $0.4 \%$ at both $2.349 \mathrm{ppm}$ and 10200 $\mathrm{ppm}$, and the precision of the TCD was $1.5 \%$ at $10200 \mathrm{ppm}$.

CII, concentrations in water samples were deternined by headspace equilibration technique. An equivalent volume of UHP $\mathrm{N}_{2}$ was added to the sample then shaken for a minimum of 2 minutes, and the $\mathrm{CH}_{4}$ concentration in the headspace was determined in duplicate by FID

\subsubsection{Sediment Sample Incubations}

Sediment samples were collected in mid-September from 3 sites in the beaver pond. Cores were collected from two open water sites using plastic pipe, and the ends of the pipe were sealed immediately after removal to prevent contamination. Samples of a floating mat were obtained using a knife to cut out mat layers which were transferred into mason jars under water to prevent disturbance of the samples.

Sediments were stored at $4{ }^{\circ} \mathrm{C}$ until the incubation experiment in the fall of 1994 .

Laboratory incubations of the sediment samples were performed to determine potential rates of $\mathrm{CH}_{4}$ production and consumption under anaerobic and aerobic cunditions, respectively. Cores were divided into $10 \mathrm{~cm}$ depth intervals, and triplicate (anaerobic incubations) or duplicate (aerobic incubations) samples of approximately 5 $\mathrm{g}$ of wet peat from each layer and $5 \mathrm{ml}$ of pond water were transferred into $60 \mathrm{~mL}$ Erlenmeyer flasks which were fitted with SubaSeals. Aerobic $\mathrm{CH}_{4}$ consumption 
potentials were determined by injecting 50$) \mathrm{Hl}$ of pure ( $\mathrm{Cl}, 4$ into the llasks, which were shaken on a yrotory slaker at $250 \mathrm{rpm}$ to prevent the formation of analerobic pockets in the sediments, and observing the decrease in $\mathrm{CH}_{4}$ concentration over time. Anaerobic production potentials were determined by twice evacuating the lasks and backflushing with $\mathrm{N}_{2}$ so that little initial $\mathrm{CH}_{4}$ remained, and the increase in $\mathrm{CH}_{4}$ concentration in the flask headspace was deternined by samıling daily lor 5 days. Between sampling, the flasks were incubated in the dark at room temperature.

After the incubations were completed, the samples were oven dried at $60^{\circ} \mathrm{C}$. A regression of the change in $\mathrm{CH}_{4}$ concentration over time was then expressed as mass of $\mathrm{CH}_{\downarrow}$ produced or consumed per mass of oven-dry sediment. The samples were then combusted in a $450^{\circ} \mathrm{C}$ muffle furnace to determine organic matter content.

\section{3 .3 Isotopic Analysis}

Bubble and porewater samples were collected for isotopic analysis in lateAugust and September. Samples were transferred to $160 \mathrm{ml}$ vials using an inverted vial technique (Jeff Chanton, personal communication) to prevent piercing the vial stopper. The samples were stored upside-down and frozen to prevent leakage. In February, 1995, the samples were analysed at Florida State University. Samples were prepared for carbon isotope analysis by combusting the $\mathrm{CH}_{4}$ to $\mathrm{CO}_{2}$ in a helium gas stream passing over $800^{\circ} \mathrm{C}$ copper oxide, cryogenically purifying the $\mathrm{CO}_{2}$ and sealing the sample in a glass tube (Chanton et al., 1992). Hydrogen isotopes (Coleman et al., 1981) were determined by combusting the samples, trapping the released water and liberating the $\mathrm{H}_{2}$ by heating the tubes at $500^{\circ} \mathrm{C}$ for 30 minutes in the presence of $\mathrm{Zn}$. 
${ }^{11}($ and $\mathrm{D})$ (deuterium) were analyzed on a mass spectrometer. Results were corrected for line blanks and expressed in delta notation (liy. 4).

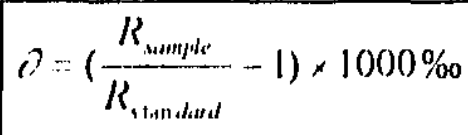

[Eq. 4]

where $\mathrm{R}$ in the respective isotope ratio $\left({ }^{1.3} \mathrm{C} /{ }^{12} \mathrm{C}\right.$ or $\left.\mathrm{D} / \mathrm{I} \mathrm{I}\right)$

and the standard is Peedec belemnite (PDB) for carbon and standard mean ocean water (SMOW) for hydrogen

\subsection{Data Analysis}

All fluxes and storage were calculated as described above, then flux data were divided according to site vegetation characteristics, and mean daily flux was calculated for each category. Cumulative emissions were calculated by interpolating the daily means for days with missing data and summing all daily means for the season. Total emissions were calculated by adding bubble and chamber flux measurements.

Statistical analyses included regression, Mann-Whitney U-tests and Spearman corrclations. A list of data available through BORIS (BOREAS Information Systems) appears in Appendix 1 . 


\section{Chapter 3: Results}

\subsection{Environmental Variables}

The 1994 field season was warm and dry, with total precipitation of 350 (I) (Fig. 3. 1a) from May 20 (Julian day 140) to September 17 (J.d. 260) (sec Appendix II for conversions from Julian days to calendar days). Pond water level (ligh. 3. Ib) rose during snowmelt, but declined sharply after a dam failure on Junc 22 ( J.d. 173). Once the beavers repaired the dam it was observed to remain intact for the remainder of the field season. Water level peaked $(136.2 \mathrm{~cm}$ at the staff gauge, relative to an arbiltary datum) on July 20 (J.d. 201), and then declined gradually through the end of the field season.

Mean daily air temperature (Fig. 3,2a) ranged from $4.2^{\circ} \mathrm{C}$ to $21.4^{\circ} \mathrm{C}$.

Temperatures in the pond reflected ambient air temperatures (Fig. 3.2b), but fluctuated less due to the higher heat capacity of water. Pond water temperatures often exceeded mean daily air temperature and never fell below $10^{\circ} \mathrm{C}$. Pond sediment temperatures also followed air temperature (Fig. 3.3 ), but exhibited a lag (4 days at $20 \mathrm{~cm}$ and 5 days at $40 \mathrm{~cm}$ depth) with smaller fluctuations. At $1.5 \mathrm{~m}$ depth, the sediment temperature increased linearly from 2.7 to $7.0^{\circ} \mathrm{C}$ throughout the season.

Photosynthetically active radiation (PAR) fluctuated greatly (Fig. 3.4). From July 1 - 6 (J.d. 182 through 187), smoke from forest fires dramatically reduced PAR. Underwater PAR, measured 50 to $70 \mathrm{~cm}$ below the water surface (l.ig. 3.4), was typically $10 \%$ of that incident at the surface.

Mean daily atmospheric pressure (Fig. 3.5) fluctuated between 98.5 and 101.5 $k \mathrm{~Pa}$ throughout the field season, but the majority of the many fluctuations were less 


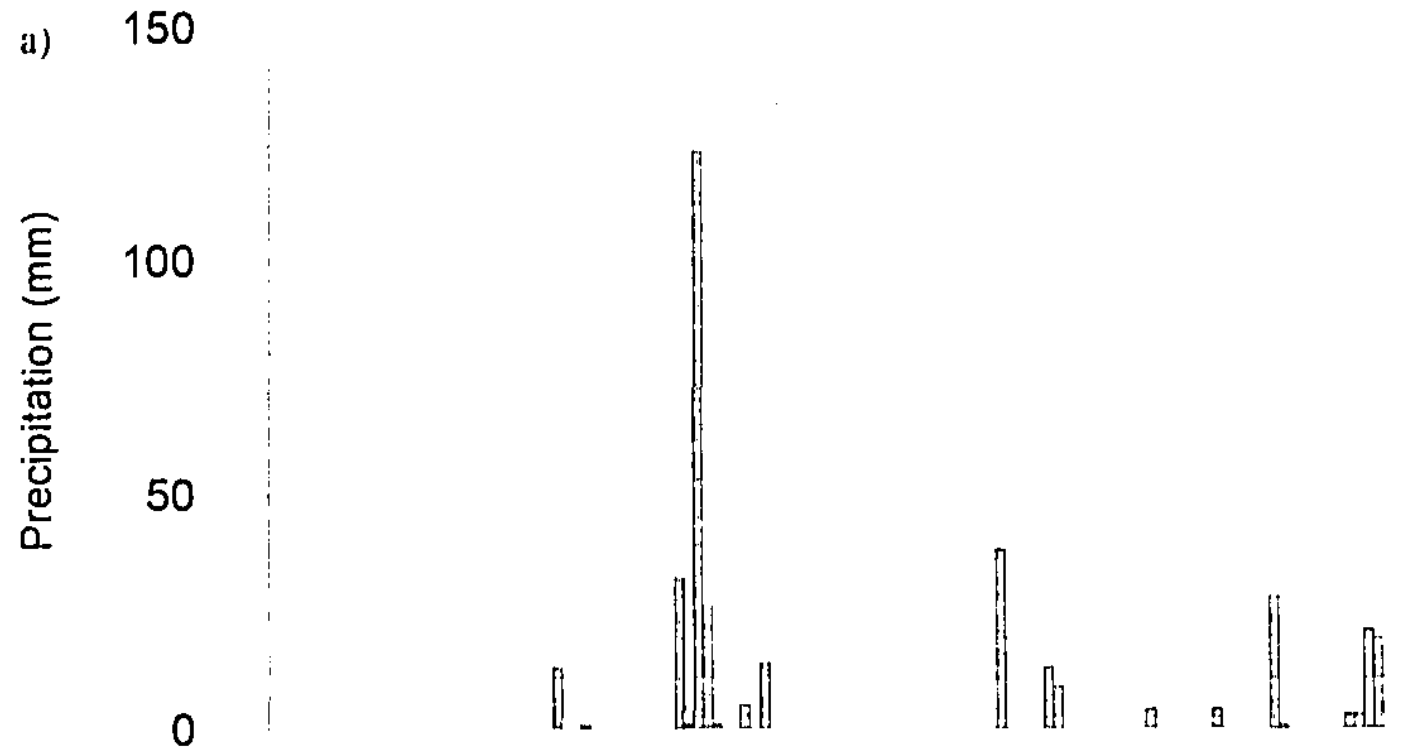

b) 140

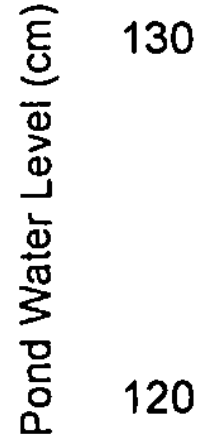

110

$\begin{array}{llllllllll}140 & 154 & 168 & 182 & 196 & 210 & 224 & 238 & 252 & 266\end{array}$ Julian Day

Fig. 3.1 a) Total Daily Precipitation and b) Beaver Pond Water Level 


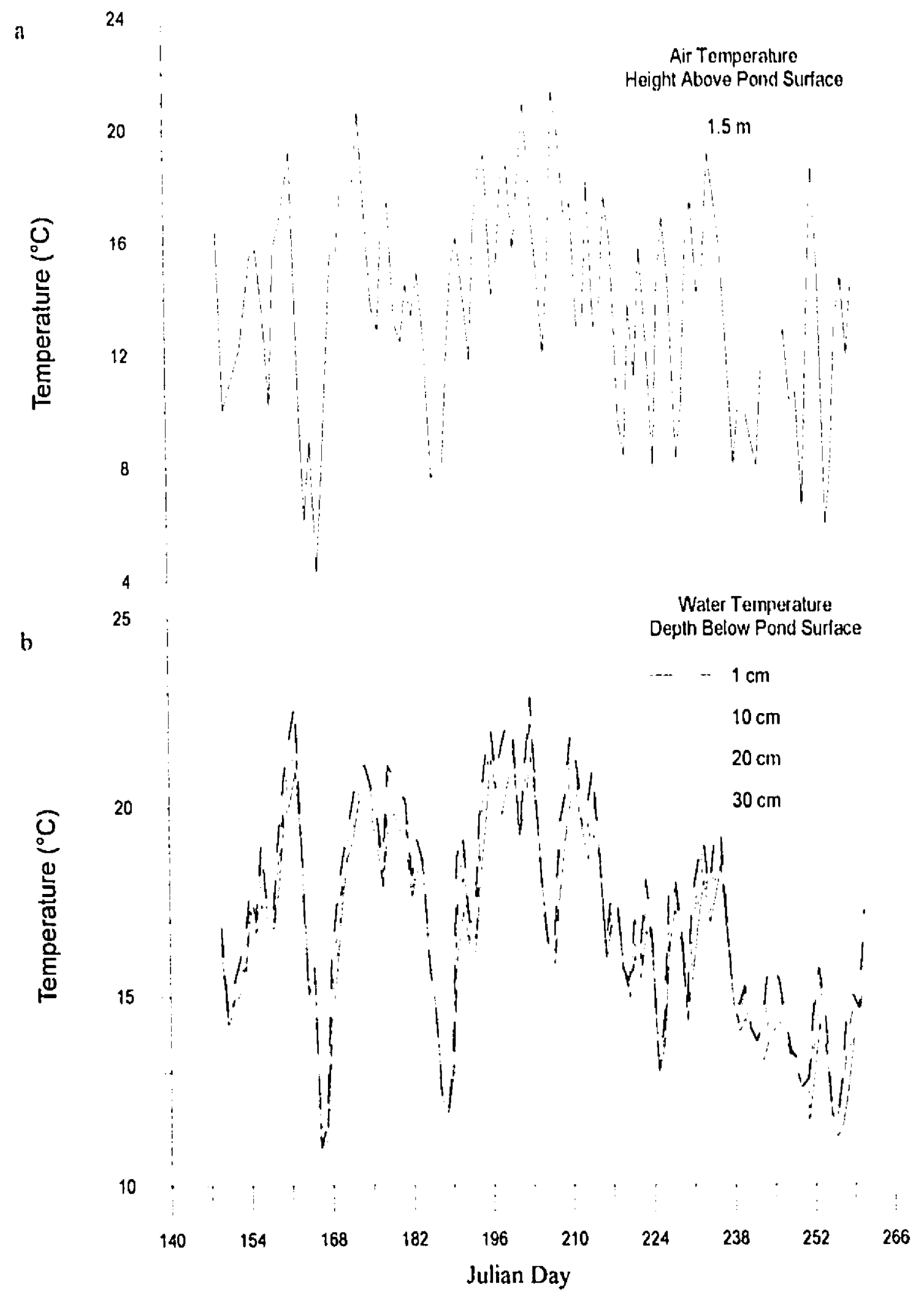

Fig. 3.2 a) Mean Daily Air Temperature and b) Mean Daily Pond Water Temperature 


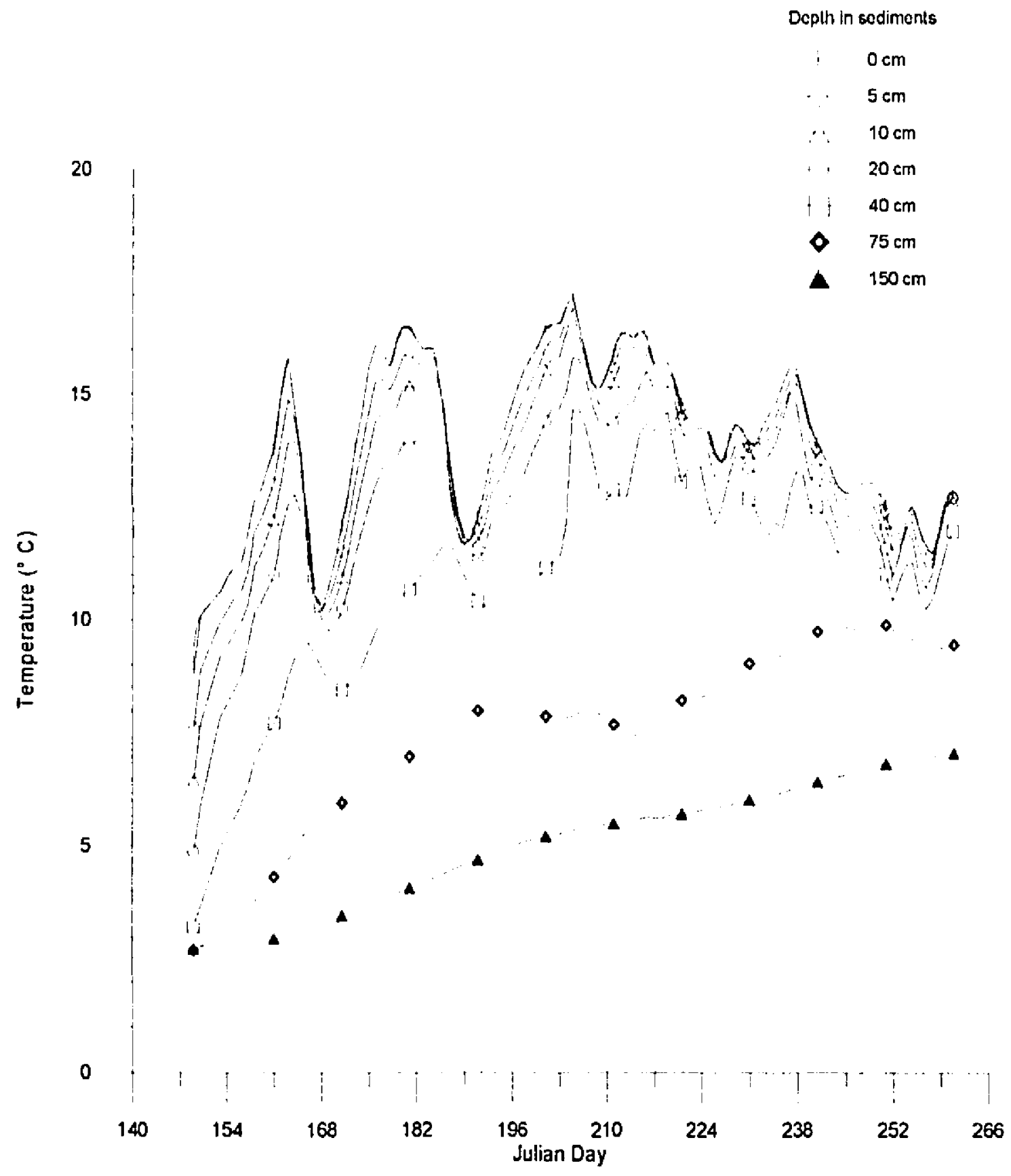

Fig. 3.3 Mean Daily Pond Sediment Temperature 


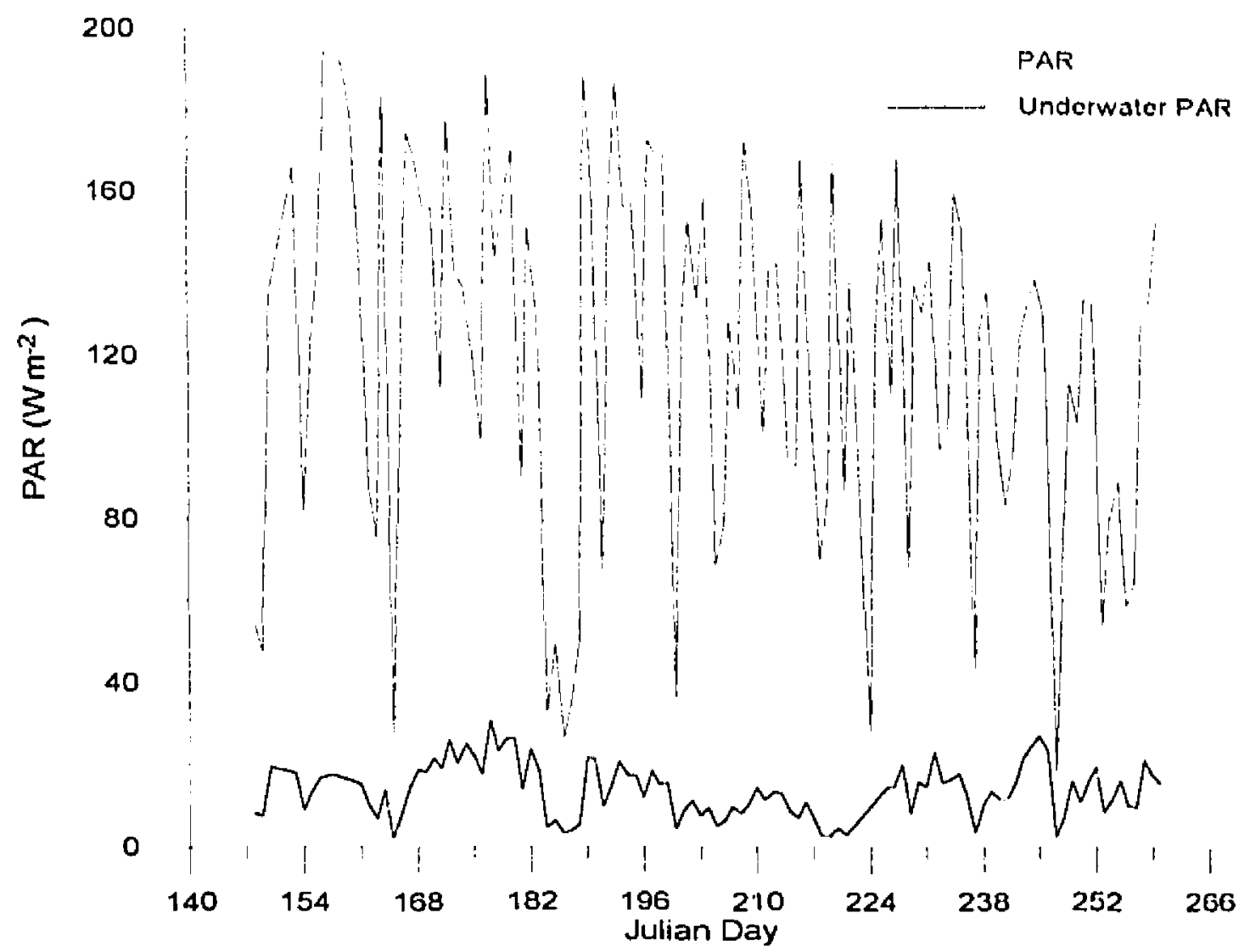

Fig. 3.4 Mean Daily Daytime PAR and Underwater PAR

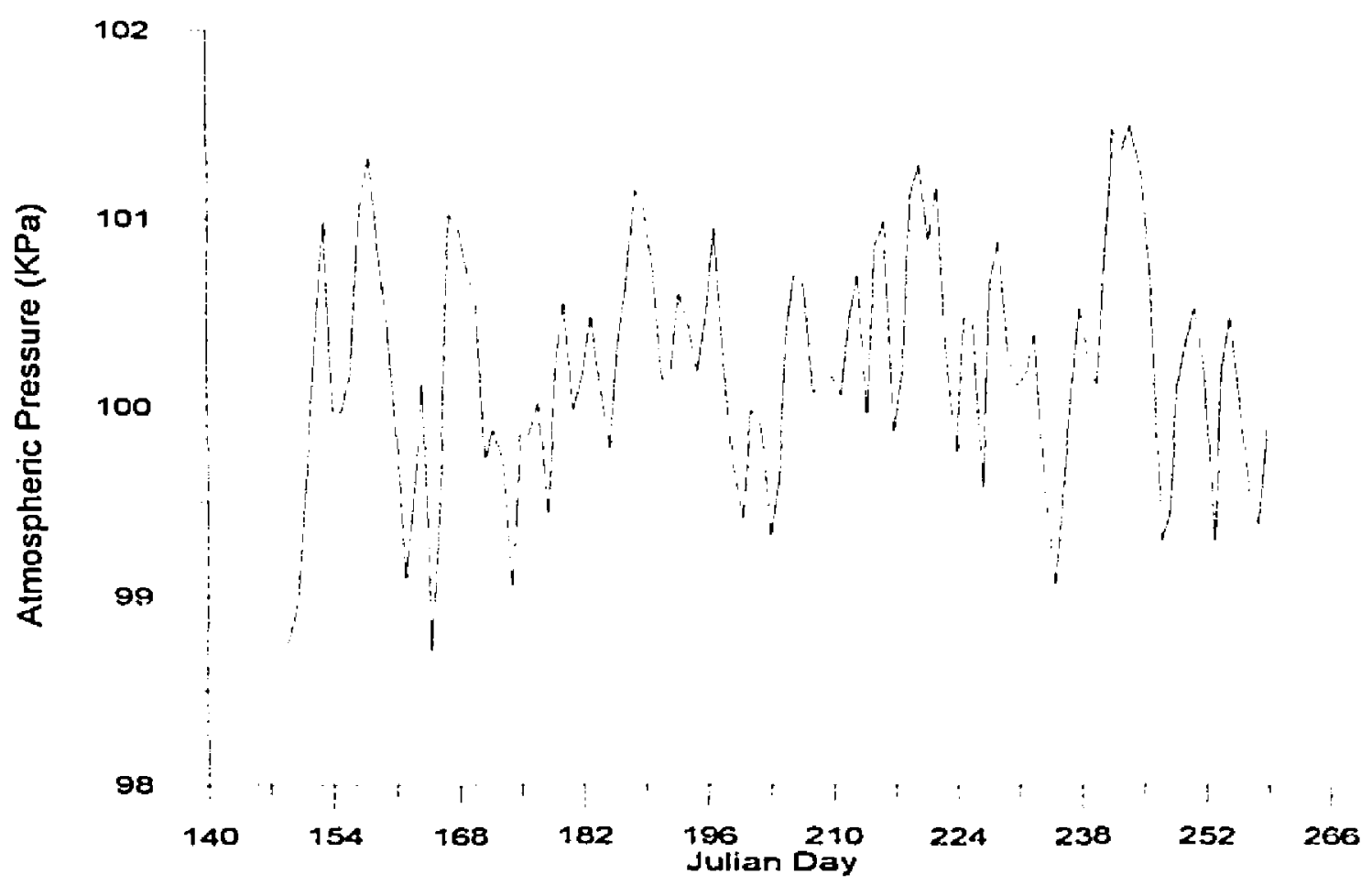

Fig. 3.5 Mean Daily Atmospheric Pressure 
than I kPa. The maximum 24-hour change was an increase of $2.1 \mathrm{kPa}$. Mean daily windspeed ranged from 0.46 to $3.65 \mathrm{~m} \mathrm{~s}^{-1}$, and maximum half-hour windspeeds ranged from 1.69 to $5.98 \mathrm{~m} \mathrm{~s}^{-1}$. Winds were calm at night and in the carly morning and there were usually several hours each day when it was also calm.

\subsection{Chamber Fluxes}

A total of 260 chamber fluxes were obtained on 42 days from May 20 (J.d. 140) to September 13 (J.d. 256). An additional 53 flux measurements were made during two 24-hour periods in June and July to examine diel trends in diffusive fluxes from the beaver pond. Fluxes ranged from -7.2 to $1080 \mathrm{mg} \mathrm{CH}_{4} \mathrm{~m}^{-2} \mathrm{~d}^{-1}$, and the distribution was positively skewed (skewness $=2.3$; Fig. 3.6). Approximately $75 \%$ of all fluxes were below $157 \mathrm{mg} \mathrm{Cl}_{4} \mathrm{~m}^{-2} \mathrm{~d}^{-1}$. The mean flux was $139.2 \pm 194 \mathrm{mg} \mathrm{CH}_{4}$ $\mathrm{m}^{-2} \mathrm{~d}^{-1}$, and the median was $60.3 \mathrm{mg} \mathrm{CH} \mathrm{m}^{-2} \mathrm{~d}^{-1}$. Geometric means were not calculated because several fluxes were $\leq 0$.

\subsubsection{Vegetation and Site Differences}

The chamber flux measurements were divided into 7 different vegetation categories (Fig. 3.7 and Table 3.1): open water; (arex sp. (sedges); Nymphaea sp. (waterlilies); Sallix sp. (willows); Lquisetum sp. (horsetails); ('alamagrostis canadensis (grasses); and Typha.sp. (cattails). Fluxes were lowest over ('alamagrostis $(9.9 \pm 9.6$ $\left.\mathrm{mg} \mathrm{CH}_{4} \mathrm{~m}^{-2} \mathrm{~d}^{-1}, \mathrm{n}=2\right)$, Liquisetum (50.8 $\left.\pm 53.4 \mathrm{mg} \mathrm{CH}_{4} \mathrm{~m}^{-2} \mathrm{~d}^{-1}, \mathrm{n}=6\right)$, Nymphaca $(50.7$ $\left.\pm 65 \mathrm{mg} \mathrm{CH}_{4} \mathrm{~m}^{-2} \mathrm{~d}^{-1}, \mathrm{n}=17\right)$, and Salix $\left(35.3 \pm 29.5 \mathrm{mg} \mathrm{CH}_{4} \mathrm{~m}^{-2} \mathrm{~d}^{-1}, \mathrm{n}=5\right)$. Fluxes 


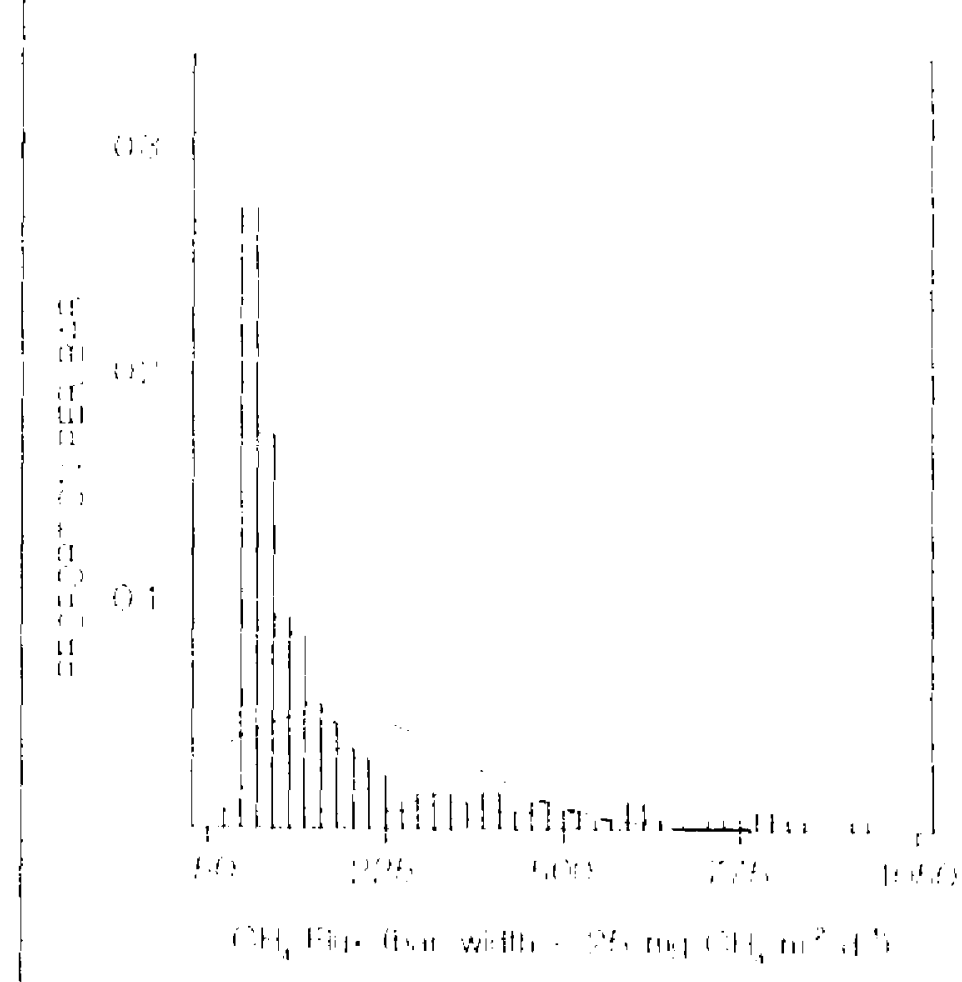

Fig. 3.6 Distribution of All Chamber Fluxes

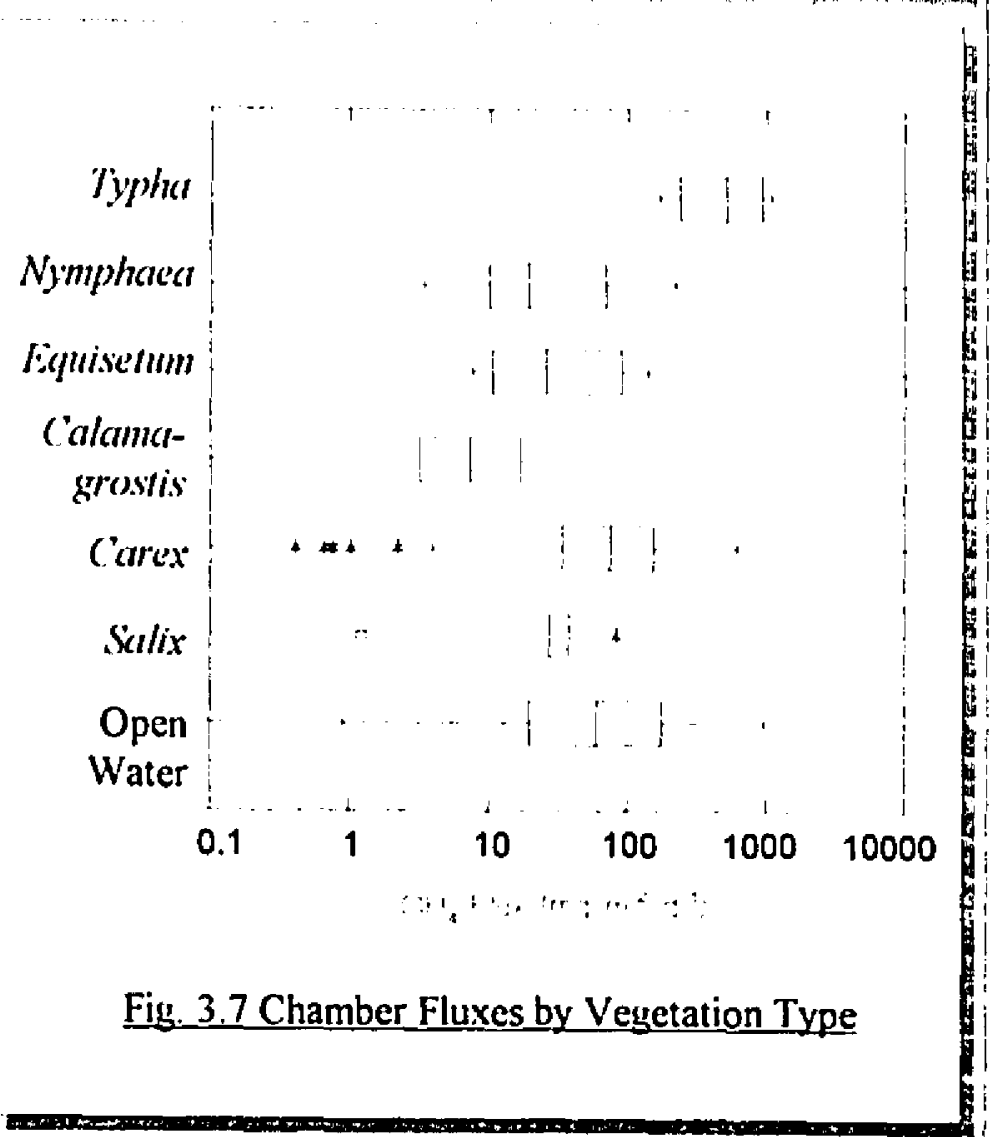

Table 3. 1: Chamber Flux Data by Vegetation Type (liluxes in mg $\mathrm{CJh}_{4} \mathrm{~m}^{\prime \prime} \mathrm{d}^{1}$ )

Open Water:

$$
N=121
$$$$
\min { }^{-}-3.9
$$

$\max :-9.57 .3$

mean 161.2

$\mathrm{SI})=22.3 .5$

$\mathrm{CV}=1.39$

median $\div 57.7$

$$
\begin{gathered}
\text { Curd: } \\
N=105 \\
\min --7.2 \\
\text { max }-621.0 \\
\text { mean }=123.5 \\
S D=138.2 \\
C V=1.12 \\
\text { median }=70.5
\end{gathered}
$$

Salix:

$N=5$

median - 27.7

$\mathrm{SD}-29.5$

Galamagrosis:

$\mathrm{N} \div 2$

median $=9.9$

$\mathrm{SD}=9.6$

Eguinsotmm:

$N=6$

median $=28.7$

$\mathrm{SD}=53.4$

Nymmlnasa:

$\mathrm{N}=17$

median $=19.1$

$\mathrm{SD}=6.5$

Typher:

$N=4$

median $=563.4$

$\mathrm{SD}=418.5$ 
from sites containing ('crece (123.5 $\left.\pm 138.2 \mathrm{mg} \mathrm{CH}_{4} \mathrm{~m}^{-2} \mathrm{~d}^{-1}, \mathrm{n}=105\right)$ and open water (161.2 $\pm 223.6 \mathrm{mg} \mathrm{CH}_{4} \mathrm{~m}^{-2} \mathrm{~d}^{-1}, \mathrm{n}=121$ ) were higher. Typhat had the highest fluxes (594.3 $\left.\pm 418.5 \mathrm{mg} \mathrm{CH}_{4} \mathrm{~m}^{-2} \mathrm{~d}^{-1}, \mathrm{n}^{-4}\right)$. The highest measured flux (1080 $\mathrm{mg} \mathrm{CH}_{4} \mathrm{~m}^{-2}$ $\mathrm{d}^{-t}$ ) was obtained from a chamber enclosing a $/ y$ pha plant. There were no statistically significant differences between fluxes from any two vegetation groups (Mann Whitney U tests, $p>0.05$ ). In several cases this may have been due to small sample sizes.

A further category comprised fluxes measured from a stagnant pool near the north pond outflow. These fluxes were high (432.9 $\left.\pm 229 \mathrm{mg} \mathrm{CH}_{4} \mathrm{~m}^{-2} \mathrm{~d}^{-1}, \mathrm{n}=6\right)$, likely due to a buildup of $\mathrm{CH}_{4}$ in surface waters from the lack of water flow, sheltered location, and high organic content of the sediments, but these associations were not tested.

\subsubsection{Seasonal Trends and Spatial Variability}

Mean daily fluxes from open water and from ('arex sites are shown in Fig. 3.8. Fluxes were initially very small, but an emission 'pulse' was observed from June 12 to 14 (J.d. $163-165$ ), during which the flux from open water sites reached $856 \mathrm{mg} \mathrm{CH}_{4}$ $\mathrm{m}^{-2} \mathrm{~d}^{-1}$. This pulse occurred well after ice-off, and may be related to a concurrent rise in sediment temperature and a drop in atmospheric pressure and water table (see Figs. $3.1 \mathrm{~b}, 3.3$, and 3.5). For the remainder of the season, the emission patterns from open water and (arex sites were similar, with peaks and troughs generally occurring on or about the same days.

Coefficients of variation (standard deviation:mean) indicated that fluxes can be extremely variable over short distances. The average coefficient of variation was 0.62 
Mean Daily Floating Chamber Fluxes:

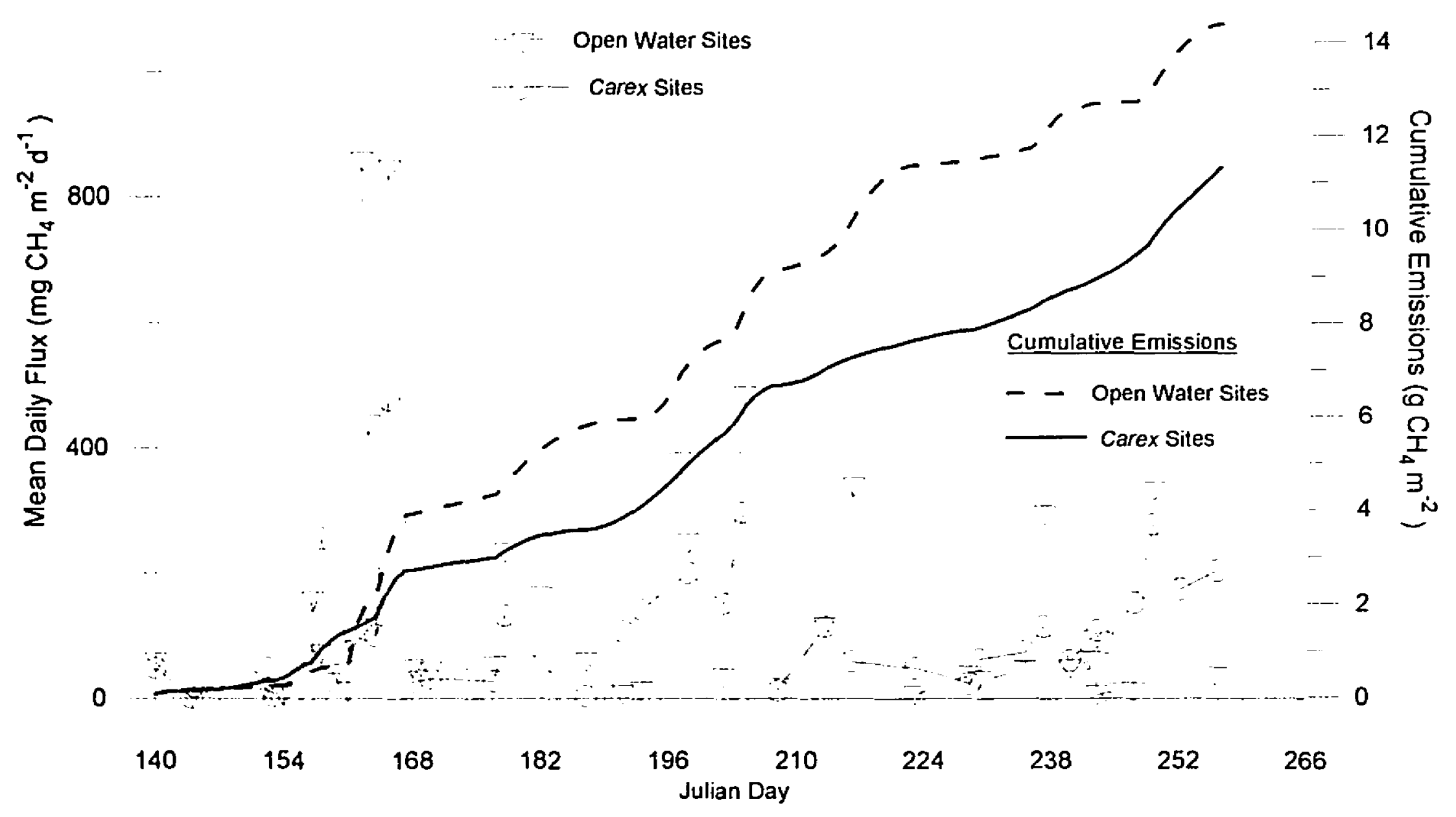

Fig 3.8. Mean Daily $\mathrm{CH}_{3}$ Flux from Floating Chambers and Cumulative Emissions 
(range $0.06-1.8$ ) for ('arex sites, and 0.64 (range $0.02-1.4$ ) for open water sites.

No significant difference was observed between mean daily fluxes from open water and ('arex sites $(U=1.62, p>0.05)$. Cumulative emissions for the season, calculated by integrating the area under the mean daily emissions curves, were $14.4 \mathrm{~g}$ $\mathrm{CH}_{4} \mathrm{~m}^{-2}\left(10.8 \mathrm{~g} \mathrm{CH}_{4}-\mathrm{C} \mathrm{m}^{-2}\right)$ from open water sites, and $11.3 \mathrm{~g} \mathrm{CH}_{4} \mathrm{~m}^{-2}\left(8.5 \mathrm{~g} \mathrm{CH}_{4}-\mathrm{C}\right.$ $\left.m^{-2}\right)$ from ('arex sites.

Measurements from an independent study of $\mathrm{CH}_{4}$ flux at the beaver pond, using a flux-gradient approach from a $1.5 \mathrm{~m}$ micrometeorological tower, showed that the flux of $\mathrm{CH}_{4}$ was greatest when the wind was blowing from the vegetated areas of the beaver pond (P. Crill and N. Roulet, unpubl. data; see Section 4.2.4). Chamber flux measurements in this study, however, indicated similar flux between ("arex sites and open water areas. For several reasons, the chamber measurements may not have detected actual enhanced flux through sedges. Most chamber fluxes were measured from the boardwalk, where the measurements were easier to obtain compared to sampling by boat, but where the density of sedges was low compared to other pond areas. In general, floating chamber sedge sites comprised only 1 to 3 ('arex. By the end of the field season, these plants had become damaged by repeated sampling.

For these reasons, the ( arcex sites along the boardwalk may not represent ('arex sites elsewhere in the pond. At the beginning of the season, floating chamber measurements were taken from both the boardwalk and other sites, but no difference between the sites was observed as fluxes were uniformly low at the time. Sampling was subsequently restricted to the boardwalk. Toward the end of the season, when it was recognized that the tower measurements showed flux differences between open 
water and vegetated areas, subseguent chamber fluxes were measured using a boat to access areas with more dense vegetation ( 4 to 12 ('arex per chamber) (lig .3.9). On these 6 dates, the flux from ( 'arex was observed to be signiticantly greater than flus from open water (Mann Whitney $U=156, p<0.0001)$. Therefore, it is likely that the ('arex chamber flux measurements reported in this study underestimate the Cl, flux from these plants.

\subsubsection{Relationships between Chamber Fluxes and finvironmental Variables}

Several analyses were performed to reveal factors that might explain variations in observed fluxes. Since fluxes and other variables were not normally distributed, Spearman correlation coefficients ( $r$ for non-normal distributions) were calculated to determine the direction and strength of relationships (Table 3.2). No significance level is available for Spearman correlations. Scatter plots of these relationships are shown in

Fig. 3.10. Since daily means of variables are most likely to describe flux variations on a similar time scale, mean daily fluxes from open water and ('arex sites were used for these analyses.

In general, open water fluxes were more strongly correlated with environmental variables than fluxes measured from ('arex sites. Open water fluxes related negatively to mean daily atmospheric pressure for the day prior to measurement, while ('arex fluxes related less strongly with pressure and exhibited no lag in response. Open water fluxes were most strongly (and p̣nsitively) related to near-surface sediment temperatures, while ('arex fluxes were only weakly related to deeper sediment 


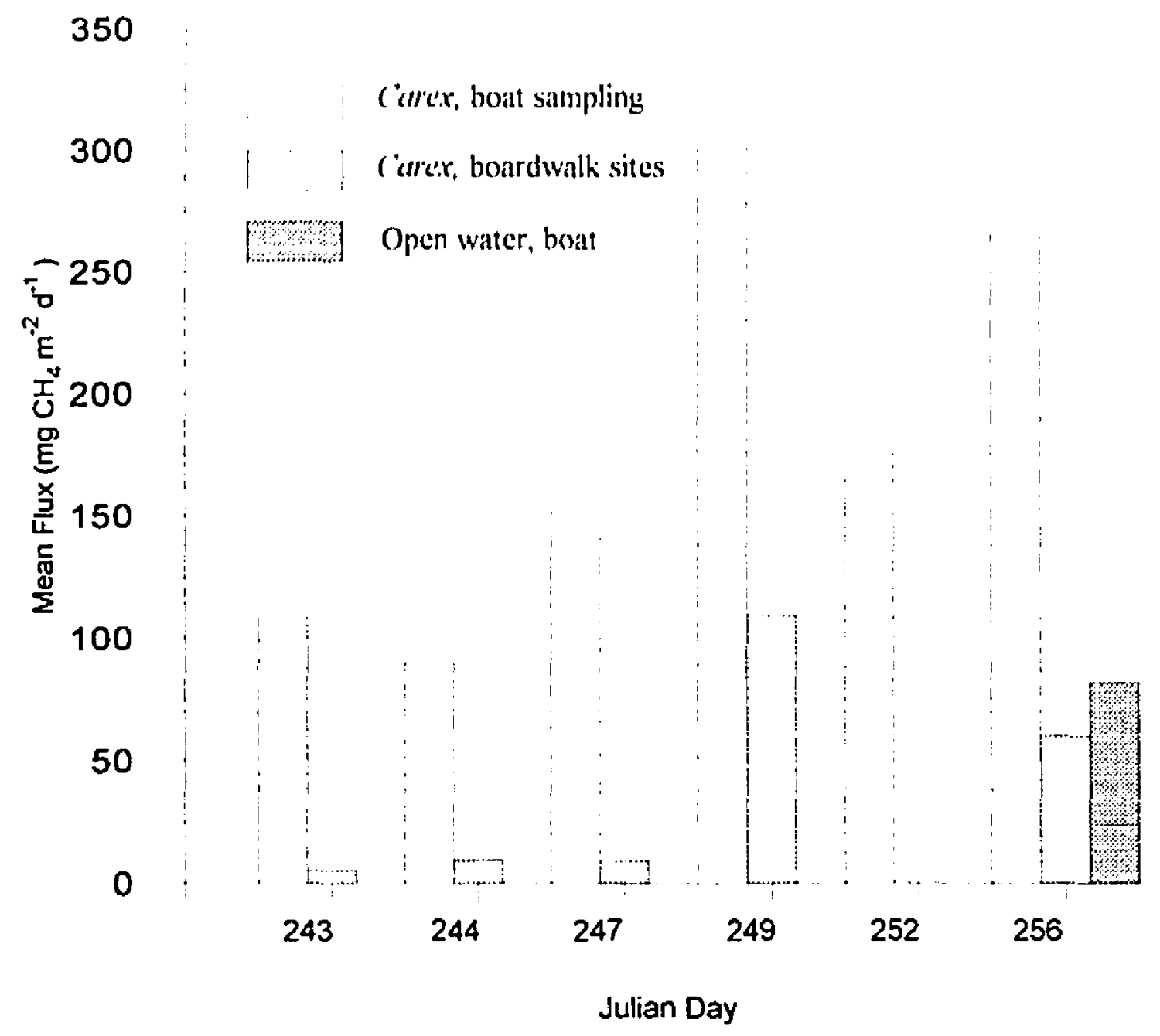

Fig. 3.9: Late-Season Evidence for Enhancement of $\mathrm{CH}_{2}$ Flux by ( $\mathrm{c}$ arex plants Dense ('urex stands (boat sampling) produced higher fluxes than adjacent open water sites or sparse ('arex stands along the boardwalk 
a)

legend:

Number reters (or depth

(in coil) below sedimenll-

water intertice

I:.g. Stilss temperalure at 5 coll below sedimentwater interface

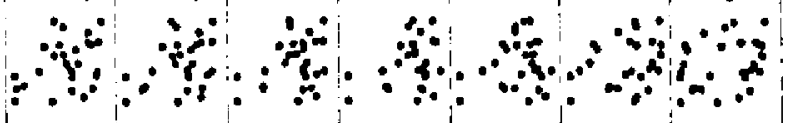

b)

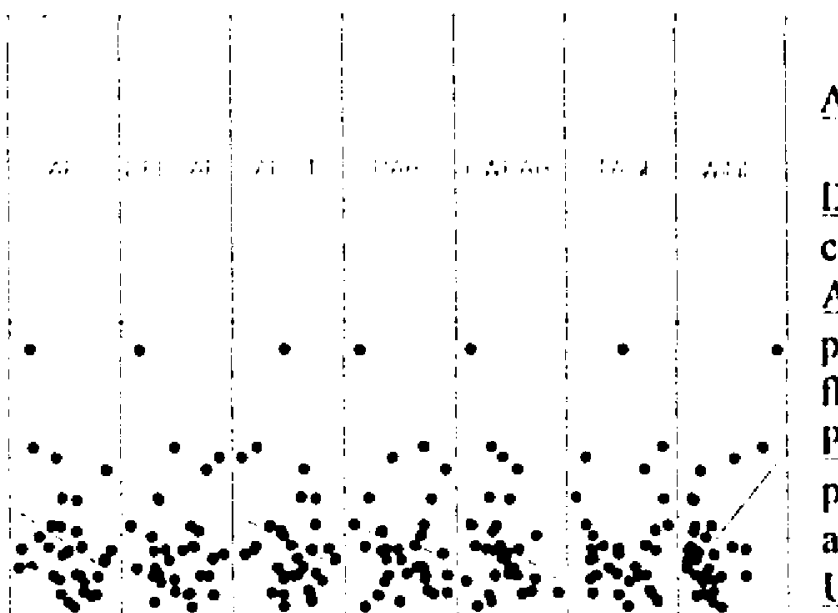

1.egend

AP: Mean daily atmospheric pressure DFL_AP: 24-hour change in alm. pressure AP I: Mean atm. pressure 1 day prior to flux measurement PAR: incident photosyntheticallya)tive radiation UWPAR: mean daily underwater PAR Stage: moan daily pond water level Wind: Mean daily windspeed

Fig. 3. 10: Scattra_Plot Matrices of Mean Daily Chamber Fluxes from Sedge ( ( arex) and Open Water Sites vs Mean Daily a) Sediment Temperatures and b) Atmospheric Pressure, PAR . Pond Stage and Windspeed 
temperatures. Fluxes were occasionally negatively related to deeper sediment temperature which may be due to the time lag of sediment temperature at depth.

Table 32 Spearman Pairwise Correlation Coefficients (r) Between Mean Daily (hamber Fluxes and Fenvironmental Variables

\begin{tabular}{|c|c|c|c|c|c|}
\hline Variable & $\%$ & $\begin{array}{c}\text { Mean Daily } \\
\text { Open Wilter Fluxes }\end{array}$ & $N$ & $\begin{array}{c}\text { Mcin Diaily } \\
\text { (arex Sitc liluxes }\end{array}$ & $N$ \\
\hline \multirow{7}{*}{$\begin{array}{c}\text { Meian Dialy } \\
\text { Sediment Temperatures }\end{array}$} & (1) & 0.50 & \multirow{7}{*}{$31)$} & 0.16 & \multirow{7}{*}{35} \\
\hline & 5 & 0.50 & & 0.11 & \\
\hline & 10 & 0.45 & & 0.09 & \\
\hline & 20 & 0.35 & & 0.012 & \\
\hline & ti) & 0.08 & & $-(0.04$ & \\
\hline & 75 & -0.12 & & 0.25 & \\
\hline & 1.50 & -0.04 & & 0.28 & \\
\hline PAR & & 0.15 & \multirow{3}{*}{38} & -0.21 & \multirow{3}{*}{34} \\
\hline Underwaller PAR & & 0.112 & & -0.20 & \\
\hline Pond Stige & & -0.01 & & $-(0.11$ & \\
\hline Almosplieric Pressurc & & -0.36 & 39 & -0.34 & 35 \\
\hline Aln Pressure Laly $=1$ daly & & -0.62 & 37 & $-1) .15$ & 33 \\
\hline Alm. Pressurc Lall = 2 dins & & -0.43 & 37 & -0.15 & 34 \\
\hline $\begin{array}{l}\text { 2t-hir change in } \\
\text { mean daily pressure }\end{array}$ & & 0.21 & 38 & -0.17 & 34 \\
\hline IVindspecd & & 0.48 & 38 & -0.03 & 34 \\
\hline
\end{tabular}

Forwards and backwards stepwise multiple linear regressions were modelled to determine the best predictive relationships for chamber fluxes (Fig. 3.11). Most relationships were weak; the best explained only $44 \%$ of the variance in flux. For the regression model of mean daily open water flux, mean daily windspeed explained $35 \%$ of the variance in fluxes $(p<0.001)$, and mean daily temperature at the sediment-water interface explained a further $9 \%$ of variance $(p<0.05)$. Mean daily windspeed was the only significant predictor of flux from ('arex sites, but relationships were much weaker than those for open water sites. 
Individual Open Water Chamber Flux $--481.4+121.48$ Mean Windspeed +32.6 Sediment-Water Intertiace Iemperature

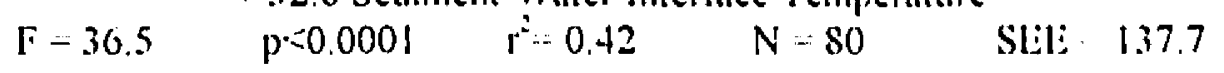

Open Water Chamber Flux ( $m g \mathrm{CH}_{4} \mathrm{~m}^{-2} \mathrm{~d}^{-1}$ )

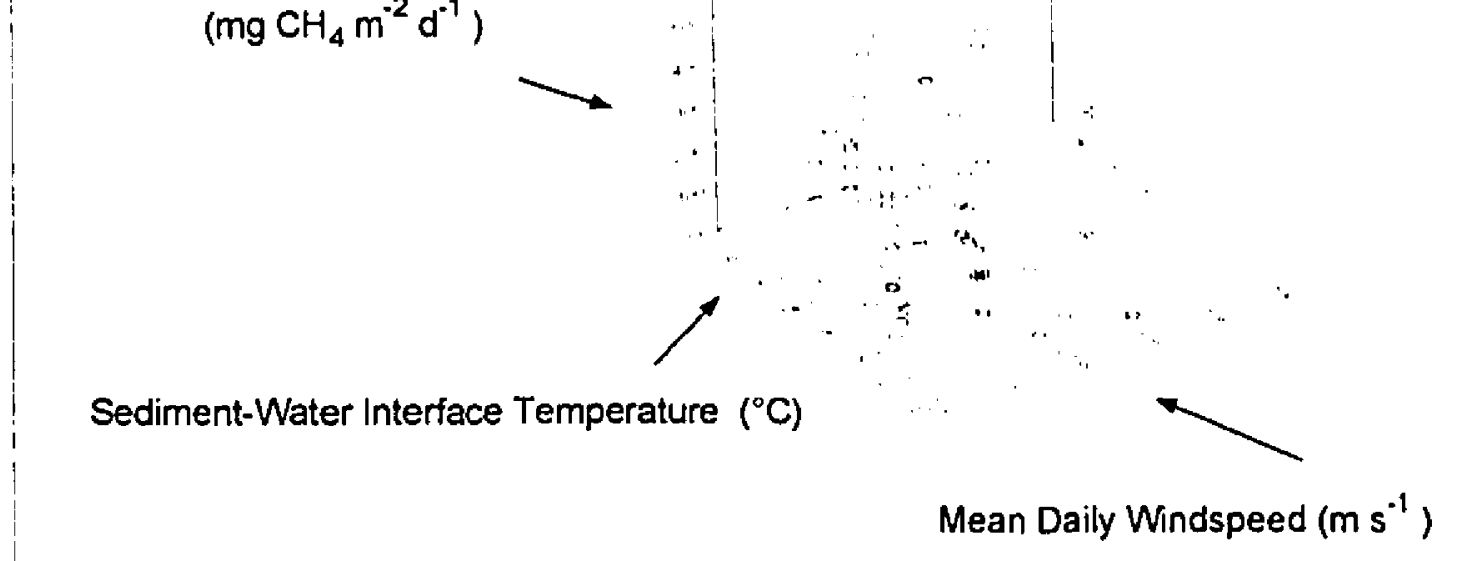

Mean Daily Open Water Chamber Flux $=-570.3+158.7$ Mean Windspeed +36.7 Sediment-Water Interface Temperature $F=13.96 \quad p<0.0001 \quad r^{2}=0.44 \quad N=38 \quad$ SIEE -164 Individual Sedge Site Chamber Flux $=58.5+53.3$ Mean Windspeed $F=11.7 \quad p<0.005 \quad r^{2}=0.11 \quad N=95 \quad$ SFE $:=133$

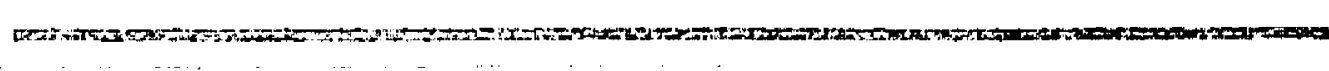
Mean Daily Sedge Site Chamber Flux $=31.4+60.9$ Mean Windspeed $F=9.6 \quad p<0.005 \quad r^{2}=0.23 \quad N=34 \quad$ SEE $=88.3$ 
To firther examine the relationships between pond sediment temperatures and chamber fluxes, the flux data were divided into specific intervals of increasing or decreasing temperature (Table 3.3). Between May 20 through June 14 (J.d. 140 105), during which sediment temperatures continuously increased, the correlation between open water chamber fluxes and sediment temperatures was strong and positive (Spearman $r>0.6$ ) (Table 3.3a). Over the same period, ('urex-site chamber

\section{Table 3.3 Spearman Pairwise Correlation Coefficients ( $r$ ) Between Chamber Fluxes and Sediment Temperatures}

a) Julian_Days 140-165: Increasing Sediment Temperatures

\begin{tabular}{|c|c|c|c|c|c|}
\hline Viriable & 1 & Open Water Fluxes & $\mathrm{N}$ & (arex Silc Fluxes & $\mathrm{N}$ \\
\hline \multirow{7}{*}{$\begin{array}{l}\text { Sedimemt } \\
\text { Temperiature }\end{array}$} & () & 0.62 & \multirow{7}{*}{ 411 } & 0.20 & \multirow{7}{*}{26} \\
\hline & 5 & 0.64 & & 0.24 & \\
\hline & 10 & 0.61 & & 0.34 & \\
\hline & 20 & 0.61 & & 0.34 & \\
\hline & 40 & 0.65 & & 0.57 & \\
\hline & 75 & 0.66 & & 0.56 & \\
\hline & 150 & 0.65 & & 0.57 & \\
\hline
\end{tabular}

b) Julian Days 190-205: Increasing Sediment 'Temperatures

\begin{tabular}{|c|c|c|c|c|c|}
\hline Variable & $\%$ & $\begin{array}{l}\text { Open Water } \\
\text { Fluses }\end{array}$ & $\mathrm{N}$ & $\begin{array}{c}\text { (arcx Sitc } \\
\text { Fluxes }\end{array}$ & $\mathrm{N}$ \\
\hline \multirow{7}{*}{$\begin{array}{l}\text { Scdiment } \\
\text { Temperature }\end{array}$} & 0 & 0.75 & \multirow{7}{*}{14} & 0.24 & \multirow{7}{*}{12} \\
\hline & 5 & 0.73 & & 0.20 & \\
\hline & 10 & 0.73 & & 0.20 & \\
\hline & 20 & 0.73 & & 0.22 & \\
\hline & 40 & 0.71 & & 0.21 & \\
\hline & 75 & $-(1) .73$ & & -0.21 & \\
\hline & 150 & 0.75 & & 0.23 & \\
\hline
\end{tabular}

c) Julian Days 214-231: Decreasing Sediment Temperatures (with fluctuations)

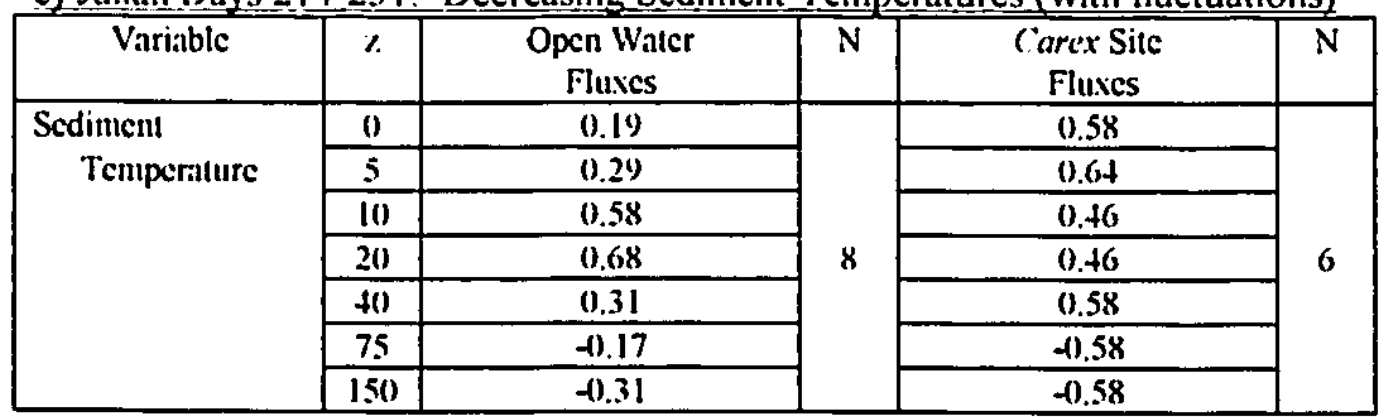

\%- depth in sediments below sediment-water interface $(\mathrm{cm})$ 
fluxes were most positively correlated with deep sediment temperatures (Spearman $r>0.56$ ). As temperatures warmed further (July 9) through 24; Jd. 190) - 20.5) open water chamber fluxes again correlated with all sediment temperatures, but fluxes from ('arex-colonized sites did not (Table 3.3b). Toward the end of the season open water fluxes correlated best with declining sedinent temperature at 10 to $20 \mathrm{~cm}$ depth, but ('arex fluxes correlated best with near-surface sediment temperatures (Table $3.3 \mathrm{c}$ ). Despite poor statistical relationships between chamber flux and temperature, the graphical trend in both is strikingly similar (Fig. 3.12).

\subsubsection{Diel Chamber Fluxes}

The diel experiment on June 20-21 (Fig. 3.13a), yielded no consistent change in flux with time of day. The July diel experiment (July 10-11) showed a pattern of increased flux from ('arex during daylight hours (8:00 to 20:00) (Fig. 3.13b). These data are inconclusive, however, due to the small sample sizes (each bar in Fig. 3.13 represents a single flux measurement) and because the spatial variability observed is greater than any detectable change in flux due to time of day. It is interesting to note that no significant relationships were found between chamber fluxes from ('arex sites and PAR or underwater PAR (above). 


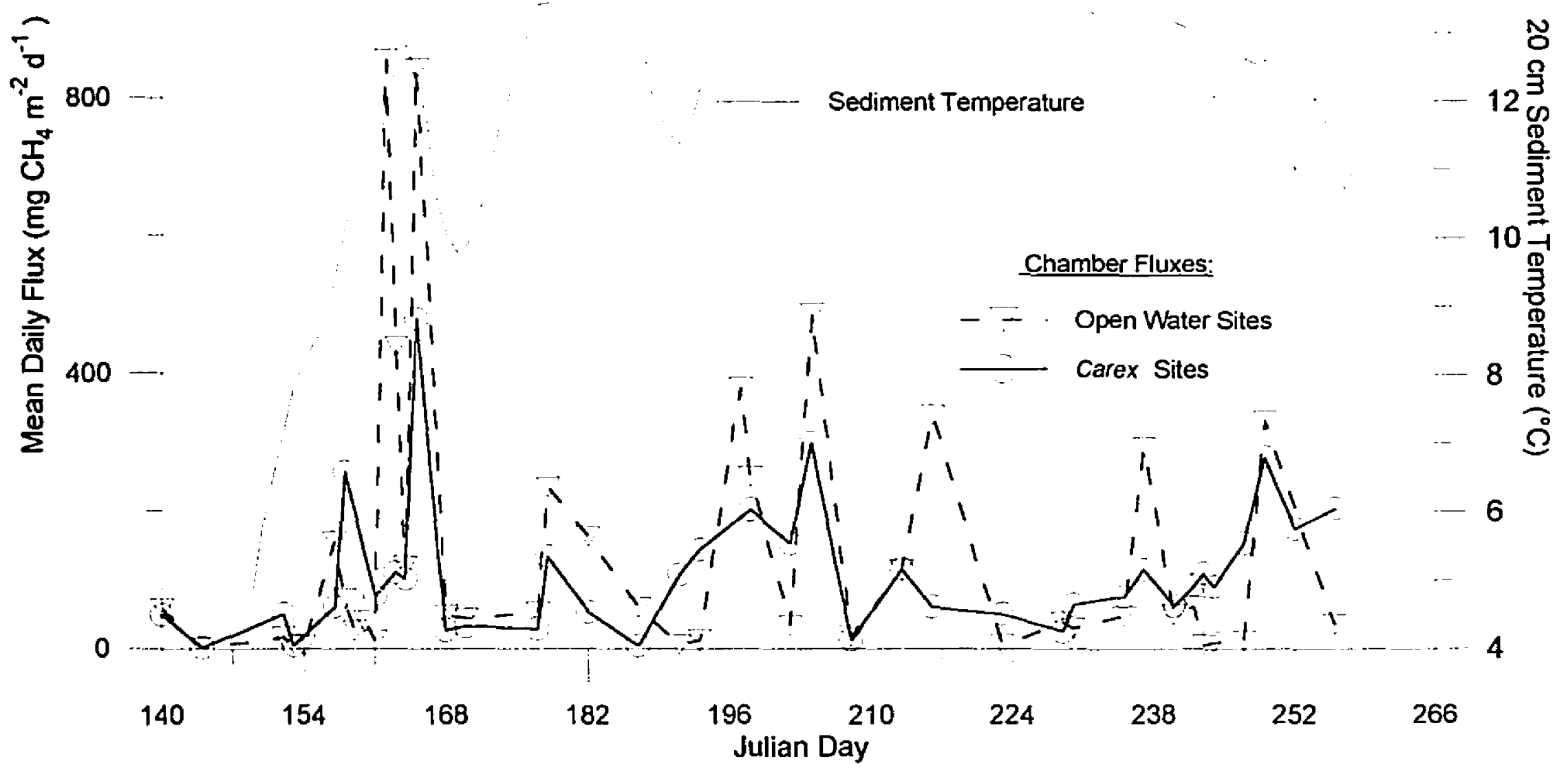

Fig. 3.12: Mean Daily Chamber Flux and $20 \mathrm{~cm}$ Sediment Temperature 


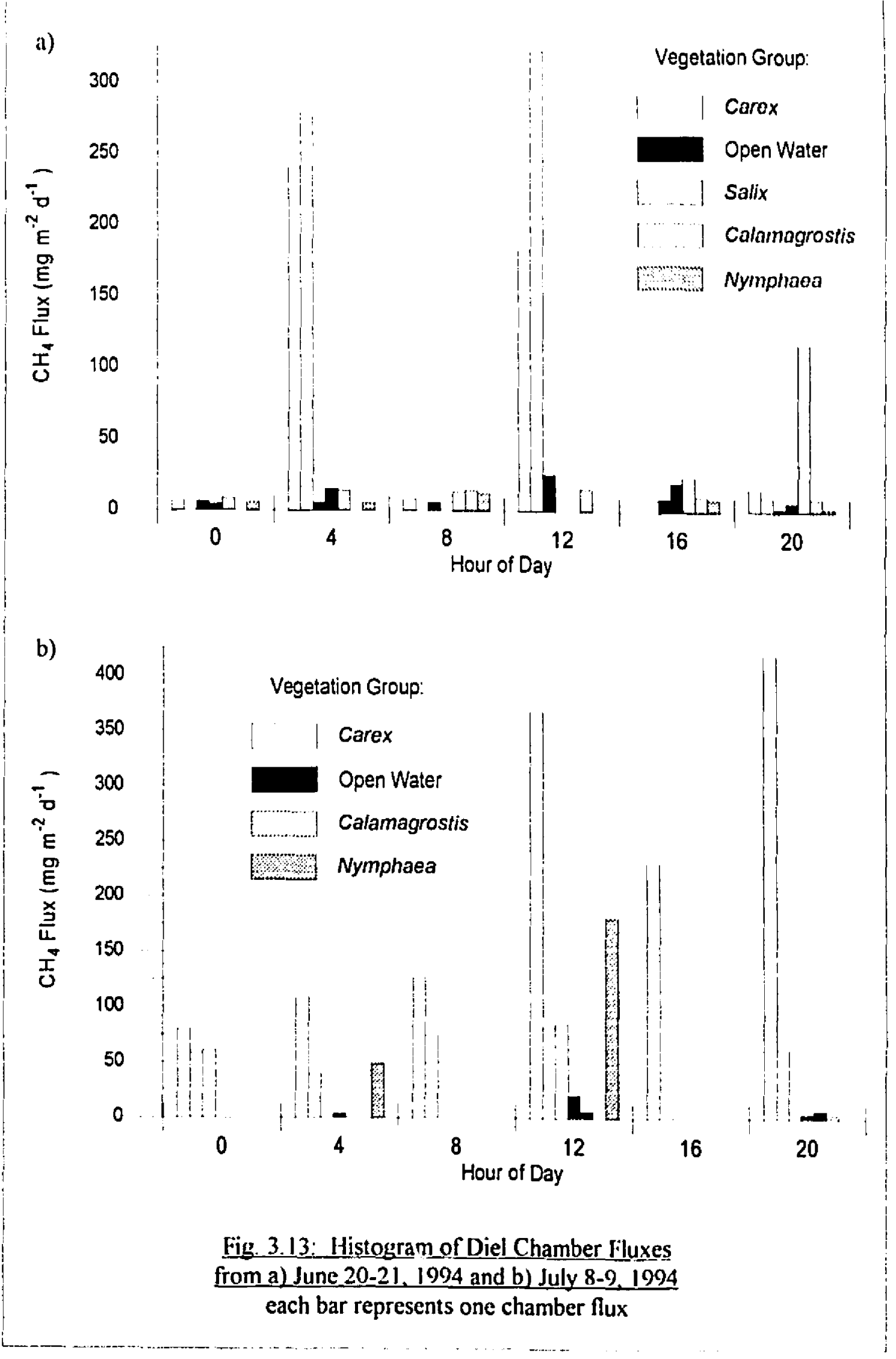




\subsection{Bubble Fluxes}

A total of 771 bubble fluxes were measured from June 6 (J.d. 157) to September 14 (J.d. 257). The minimum flux was 0 and the maximum $1849.3 \mathrm{mg} \mathrm{CH}$ $\mathrm{m}^{-2} \mathrm{~d}^{-1}$. The distribution was positively skewed (skewness $=4.6 ;$ Fig. 3.14). The mean flux was $83.8 \pm 141 \mathrm{mg} \mathrm{Cll} \mathrm{m}^{-2} \mathrm{~d}^{-1}$ and the median was $32.3 \mathrm{mg} \mathrm{CH} \cdot \mathrm{m}^{-2} \mathrm{~d}^{-1}$. Since many fluxes were zero, geometric means could not be calculated.

\subsubsection{Vegetation and Site Differences}

Bubble flux measurements were divided into open water sites and vegetated sites, which contained emergent macroplytes, notably ('arex (Table 3.4). Bubble fluxes were significanlly greater $(U=37230, p<0.0005)$ from open water sites $(159.5$ $\left.\pm 192.3 \mathrm{mg} \mathrm{CH}_{4} \mathrm{~m}^{-2} \mathrm{~d}^{-1}\right)$ than from vegetated sites $\left(30.6 \pm 33.2 \mathrm{mg} \mathrm{CH}_{4} \mathrm{~m}^{-2} \mathrm{~d}^{-1}\right)($ Fig. 3.15a), and this difference was observed at both the line $(U=9366.5, p<0.0005)$ and beam $(U=7433.5, p<0.0005)$ transects. The difference in fluxes was due both to greater bubbling rates $(U=38426.5, p<0.0005)$ (Fig. 3.15b) and higher $\mathrm{CH}_{4}$ concentrations in the bubbles $(U=14911, p<0.0005)$ (Fig. 3.15c) from open water sites. The mean open water bubbling rate and $\mathrm{CH}_{4}$ concentration were $542.8 \pm 1683$ $\mathrm{ml} \mathrm{m}-2 \mathrm{~d}^{-1}$ and $471,885 \pm 207,562 \mathrm{ppm}$, respectively. The mean rate of bubbling and average bubble $\mathrm{CH}_{4}$ concentration for vegetated sites were $165.3 \pm 285 \mathrm{ml} \mathrm{m}^{-2} \mathrm{~d}^{-1}$ and $265,951 \pm 124,300 \mathrm{ppm}$, respectively. 
a)

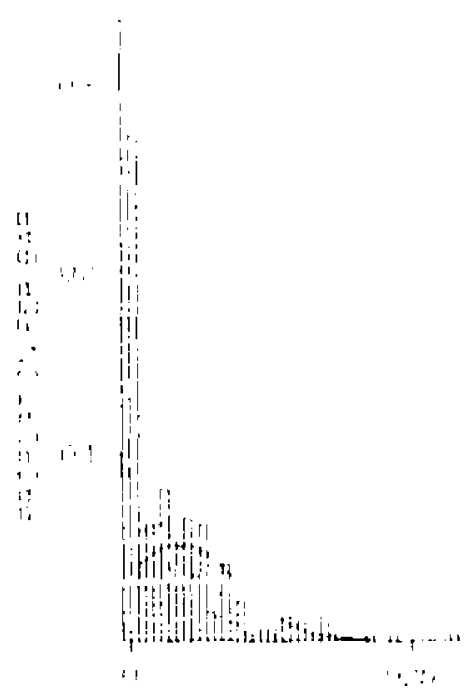

$\mathrm{CH}_{1}$ Flux (bar widıli $=2.5 \mathrm{mg} \mathrm{CH}_{1} \mathrm{ml}^{-2} \mathrm{~d}^{-1}$ ) b)

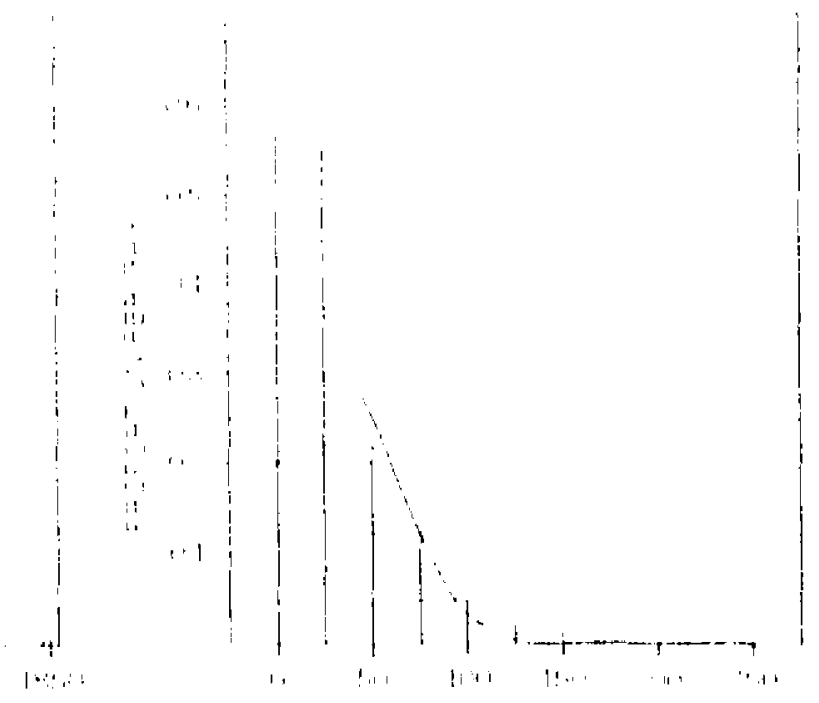

Cll, Flux (bar widlli $=25 \mathrm{mg}\left(\mathrm{Cl}, \mathrm{ml}^{2} \mathrm{~d}^{-1}\right.$ )

Fig. 3.14: Distribulions of a) Open. Water Bubble Fluxes and b) Vegetated Site Bubble Fluxes

Table 3.4 Summary of Bubble Flux Data Fluxes in $\mathrm{mg} \mathrm{CH}_{4} \mathrm{~m}^{-2} \mathrm{~d}^{-1}$

\begin{tabular}{|c|c|c|}
\hline & Open Water Sites & Vegetated Sites \\
\hline $\mathrm{N}$ & 318 & 453 \\
$\mathrm{~min}$ & 0 & 0 \\
$\max$ & 1849.3 & 342.2 \\
mean & 159.5 & 31.2 \\
\hdashline $\mathrm{SD}$ & 192.3 & 36.2 \\
\hline skewness & 3.25 & 3.06 \\
$\mathrm{CV}$ & 1.21 & 1.16 \\
\hline median & 112.5 & 19.3 \\
\hline
\end{tabular}


a)

Average Open Water Bubble fitux: 159.5 $192 \mathrm{mg} \mathrm{CII}_{4} \mathrm{~m}^{2} \mathrm{~d}^{\prime}$

Average Vegetated Site Bubble Flux: $30.6 \pm 3.3 \mathrm{mg} \mathrm{CH}_{4} \mathrm{~m}^{-2} \mathrm{~d}^{-1}$

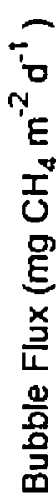

b)

Average Open Water Bubbling Rate: $542.8 \pm 1683 \mathrm{ml} \mathrm{m}^{-2} \mathrm{~d}^{1}$

Average Vegetated Site Bubbling Rate: $165.3 \pm 28.5 \mathrm{ml} \mathrm{m}^{-2} \mathrm{~d}^{-1}$

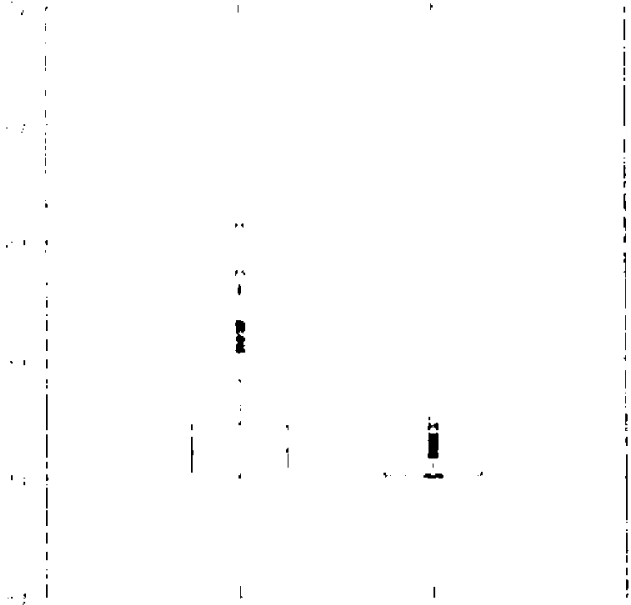

Open Water Sites

Vegetated Sites

c)

Average Open Water Bubble $\mathrm{CH}_{\downarrow}$ Concentration:

$47.2 \pm 21 \%$

Average Vegetated Site Bubble $\mathrm{CH}_{4}$ Concentration:

$26.6 \pm 12 \%$
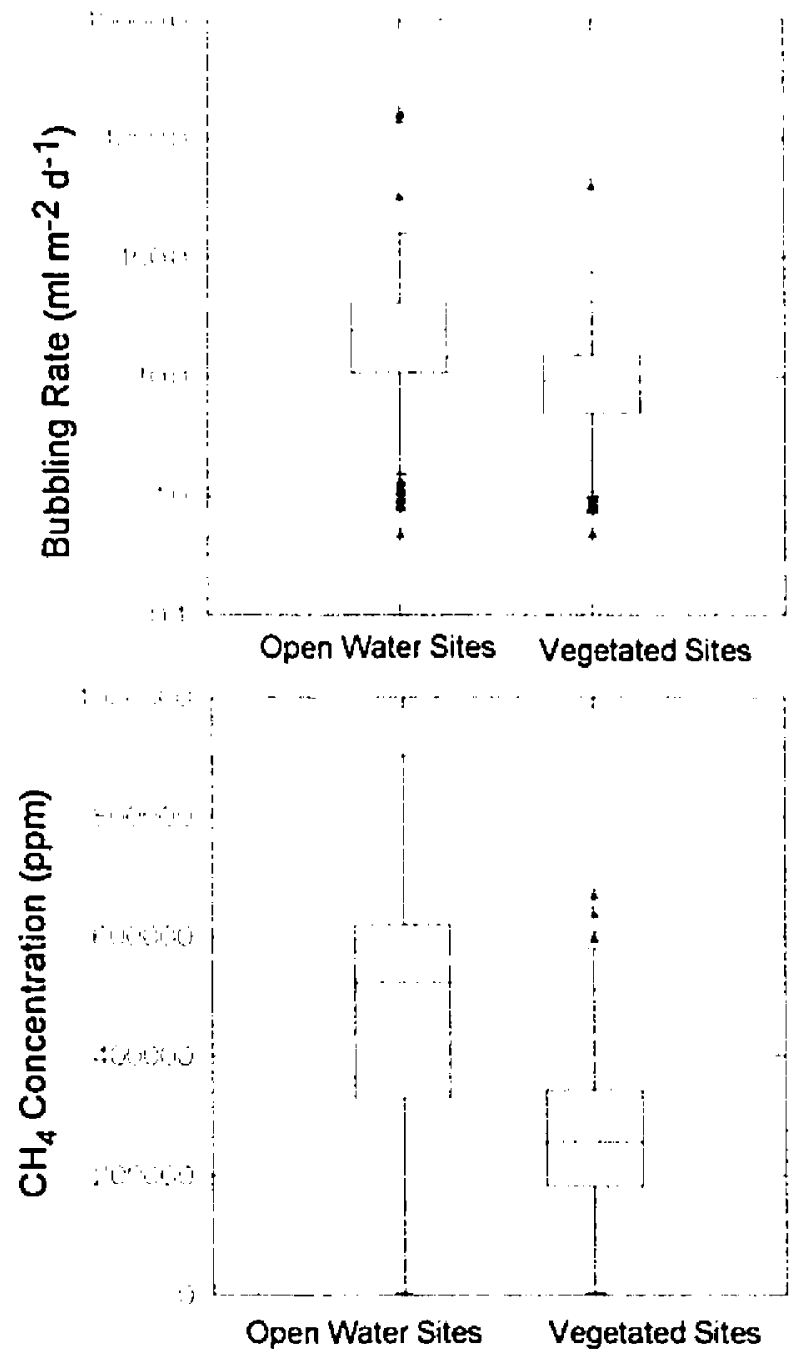

Fig. 3.15: a) Differences between bubble fluxes from open water and vegetated sites are due both to b) differences in bubbling rates and c) differences in concentration of $\mathrm{CH}_{4}$ in bubbles

Centre line of box plots are medians; edges are 25 and $75^{\text {th }}$ percentiles; asterisks are outliers; open circles are far outliers 


\subsection{Seasonal Trends and Flux Variability}

Mean daily and cumulative bubble fluxes for open water and vegetated sites are shown in Fig. 3.16. Bubble fluxes from vegetated sites were consistently lower but followed the same pattern as the open water bubble fluxes. Cumulative $\mathrm{CH}_{4}$ bubble emissions, calculated by integrating mean daily bubble fluxes over the lield season, were $2.9 \mathrm{~g} \mathrm{CH}_{4} \mathrm{~m}^{-2}\left(2.2 \mathrm{~g} \mathrm{CH}_{4}-\mathrm{C} \mathrm{m}^{-2}\right)$ from vegetated sites and $15.7 \mathrm{~g} \mathrm{Cll}_{4} \mathrm{ml}^{-2}(11.8 \mathrm{~g}$ $\mathrm{CH}_{4}-\mathrm{C} \mathrm{m}^{-2}$ ) from open water sites.

Daily coefficients of variation indicated a large spatial variability, ranging from 0.31 through 1.80 for vegetated sites and from 0.23 through 2.33 for open water sites. Coefficients of variation at a single site indicated high temporal variability, ranging from 0.40 through 1.21 for vegetated sites and 0.35 through 2.28 for open water sites.

\subsubsection{Relationships between Bubble Fluxes and Environmental Variables}

Spearman correlation coefficients were computed to test for relationships between bubble fluxes and environmental variables (Table 3.5). Mean daily open water bubble fluxes were strongly correlated with sediment temperatures to a depth of $20 \mathrm{~cm}$ $(r \geq 0.68)$. Correlations between mean daily vegetated site bubble fluxes and sediment temperature were strongest at $20 \mathrm{~cm}$ depth.

Bubble fluxes were negatively correlated with atmospheric pressure, but not to the extent that was originally hypothesized. The strength of these correlations was not improved by using relative change in pressure from the previous day (vs. relative change in bubble flux per day), nor by using time lags for response of bubble fluxes to pressure changes. Although the correlations between bubble fluxes and atmospheric 


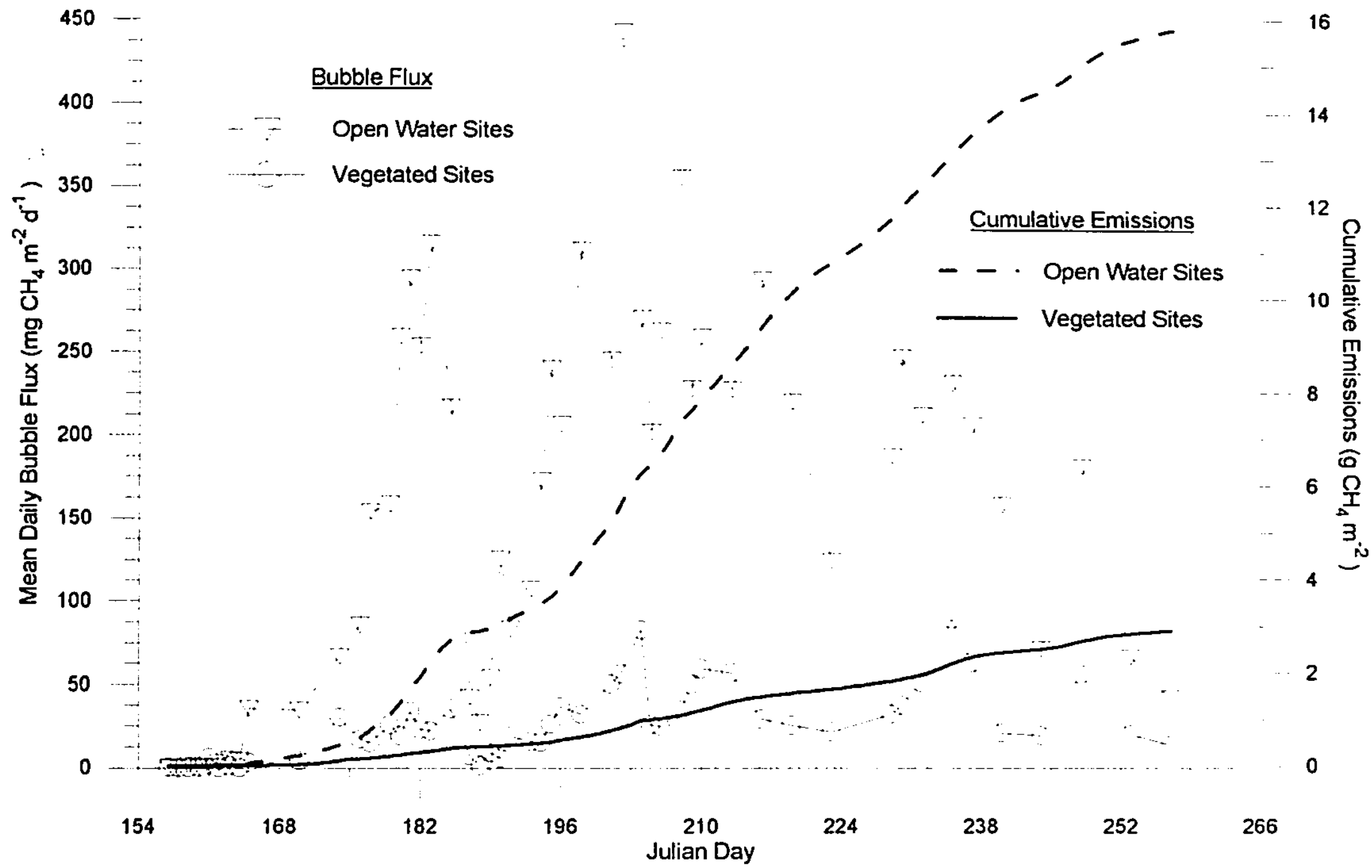

Fig. 3.16: Mean Daily Bubble $\mathrm{CH}_{2}$ Flux and Cumulative Emissions

in 
pressure were poor, their temporal trends display a high degree of syncluronicity (Fig.

3. 17). Atmospheric pressure was also found to be a significant component of the regression equations (sec below).

Table 3.5 Spearman Pairwise Correlation Coetlicients(1) Between Mean Daily Bubble Filuxes and Linvironmental Variables

\begin{tabular}{|c|c|c|c|c|}
\hline Variable & 1 & $\begin{array}{c}\text { Mean Daily } \\
\text { Open Watter lilux }\end{array}$ & $\begin{array}{l}\text { Matu Daily } \\
\text { ('arex Sile Jilux }\end{array}$ & $\mathrm{N}$ \\
\hline \multirow{7}{*}{$\begin{array}{l}\text { Mean Daily } \\
\text { Scdiment Temperallures }\end{array}$} & 11 & 0.60 & 0.55 & \multirow{7}{*}{51} \\
\hline & 5 & 0.75 & 0.60 & \\
\hline & 10 & 0.82 & 0.60 & \\
\hline & $21\}$ & 0.68 & 0.75 & \\
\hline & 4() & 0.31 & 0.71 & \\
\hline & 75 & 0.31 & 0.47 & \\
\hline & 1.50 & 11.47 & 0.60 & \\
\hline PAR & & +0.112 & 0.02 & 51 \\
\hline Undenvater PAR & & $-(0,04$ & -11.11 & 50 \\
\hline Pond Stage & & 0.16 & 0.14 & 51 \\
\hline Atmosplicric Pressure & & $-(1) .07$ & -0.26 & \multirow{6}{*}{51} \\
\hline Atm. Pressure Lajg = I day & & $-(1) .12$ & $-1) .26$ & \\
\hline Alm. Pressurc Lijg $=2$ days & & -0.20 & $-(0.09$ & \\
\hline 24-hr change in mean dails pressurc & & 0.07 & 0.113 & \\
\hline 24-lir claamge in mean pressure. lag I day & & 0.11 & -0.12 & \\
\hline 24-hr change in mean pressurc. lag 2 days & & $-1, .07$ & -11.15 & \\
\hline
\end{tabular}

\begin{tabular}{|c|c|c|c|}
\hline & $\begin{array}{l}\text { 24-hr Change in Open } \\
\text { Water Flux }\end{array}$ & $\begin{array}{l}\text { 24--1ır Change inl } \\
\text { ('arex Sitc Flux }\end{array}$ & $\mathrm{N}$ \\
\hline \multirow{3}{*}{$\begin{array}{l}24-h r \text { change in mean daily pressurc } \\
24-h r \text { change in mean pressurc. lag } 1 \text { day } \\
24-h r \text { change in mean pressurc. lag } 2 \text { dass }\end{array}$} & $-(0.19)$ & -11.23 & \multirow{3}{*}{50} \\
\hline & 0.35 & -10.36 & \\
\hline & 0.15 & 0.11 & \\
\hline
\end{tabular}

Fig. 3.18 shows the temporal trend of mean daily bubble flux with mean daily $20 \mathrm{~cm}$ sediment temperatures and pond level. The sudden $14 \mathrm{~cm}$ drop in pond water level caused by dam failure on June 22 (J.d. 173), and coincident sediment temperature increase, were associated with a large increase in mean daily open water bubble flux from 66 to $315 \mathrm{mg} \mathrm{CH}_{4} \mathrm{~m}^{-2} \mathrm{~d}^{-1}$. Both open water and vegetated site fluxes then 


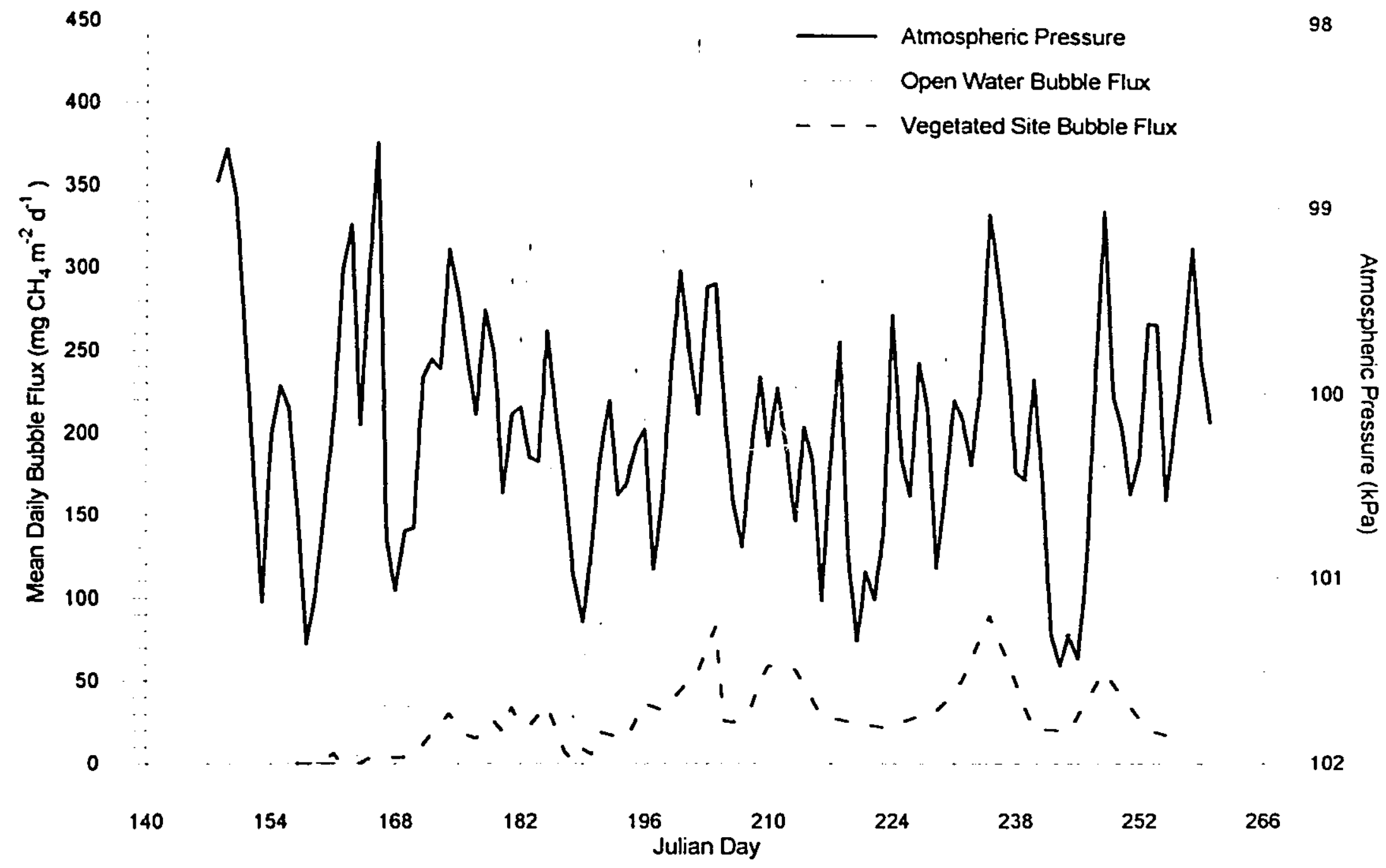

Fig. 3.17 Mean Daily Bubble Flux with Mean Daily Atmospheric Pressure

Note atmospheric pressure axis is inverted 


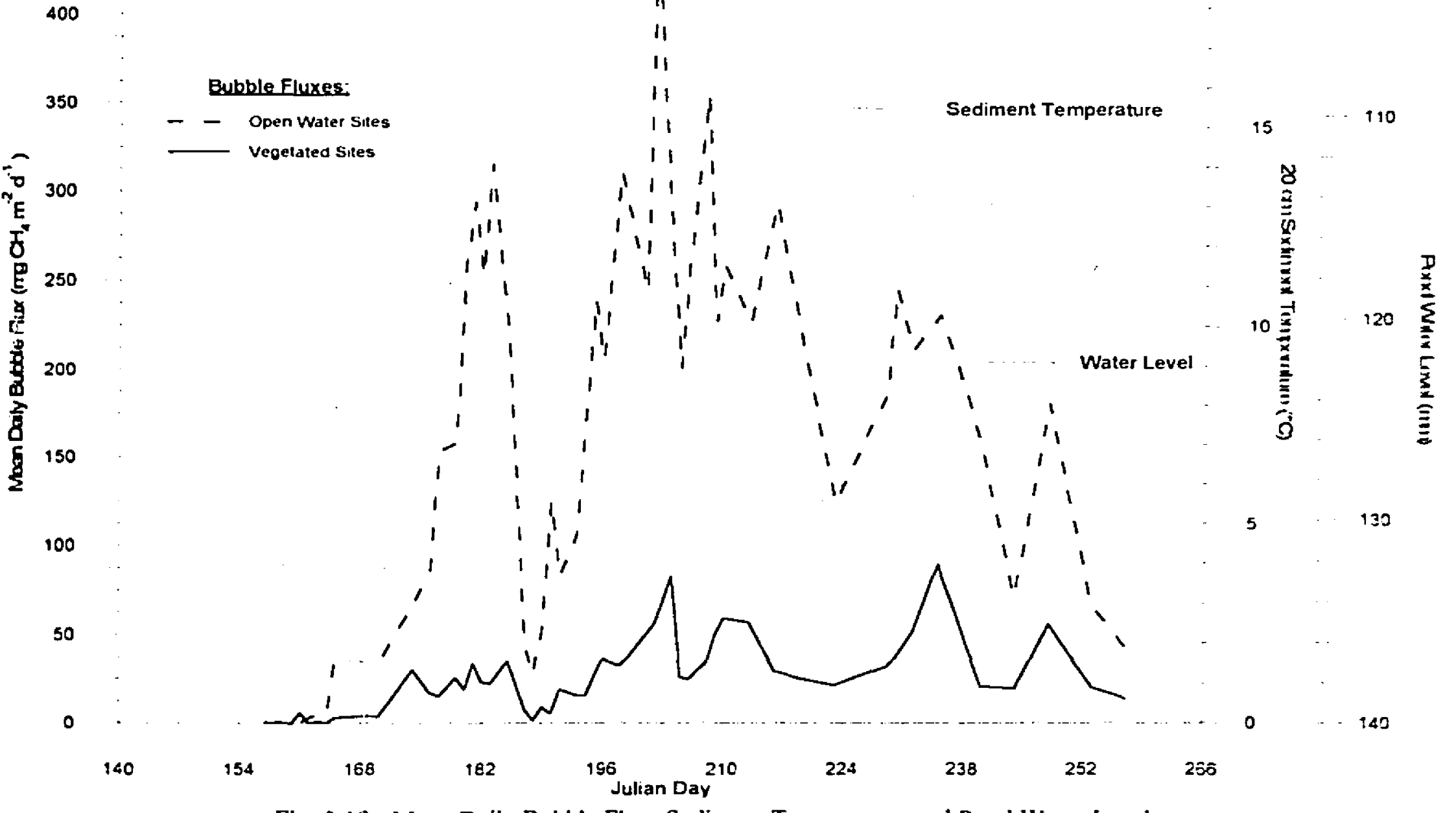

Fig 3.18 Mean Daily Bubble Flux, Sediment Temperature and Pond Water Level Note water level axis is inverted 
declined dramatically on July 4 (J.d. 185). This decline corresponded to the recovery of the pond water level, a reduction in sediment temperatures, and a rise in atmospheric pressure. Subseguent smaller changes in mean daily fluxes were also occasionally synchronous with changes in sediment temperature.

Sediment temperature at $20 \mathrm{~cm}$ depth was the strongest predictor of bubble fluxes, explaining $64 \%$ and $45 \%$ of the variance in mean daily fluxes from open water and vegetated sites, respectively. Atmospheric pressure terms explained a further $4 \%$ and $11 \%$ of variance in these fluxes. The regression equations, with significance levels. scatter plots of the relationships, and distribution of regression residuals are shown for open water sites in Fig. 3.19, and for vegetated sites in Fig. 3.20. All predictive variables were significant to $p<0.05$.

\section{3 .4 Bubble Release from Storage}

The partitioning of dissolved and gaseous $\mathrm{CH}_{4}$ stored in sediments depends on temperature and pressure according to Henry's law (e.g. Lerman, 1979). Equilibrium between dissolved and gaseous $\mathrm{CH}_{4}$ in sediments cannot be demonstrated here because they were not determined concurrently. Using Henry's law, however, the onset of bubbling (J.d. 165-170) was determined to coincide with the saturation of dissolved $\mathrm{CH}_{4}$ in porewaters at most piezometer sites. Chanton et al. (1989) have shown that dissolved $\mathrm{CH}_{4}$ in porewaters maintains equilibrium with $\mathrm{CH}_{4}$ bubbles in wetland sediments over changing pressures and temperatures. Therefore, changes in $\mathrm{CH}_{4}$ 
a)

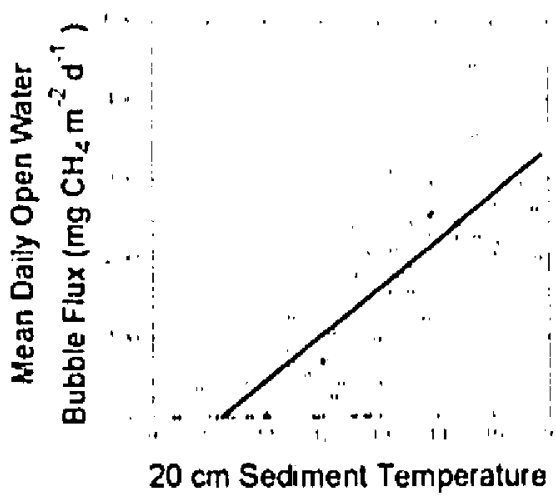

c)

Temperature $20 \mathrm{~cm}$ below sediment-water interface

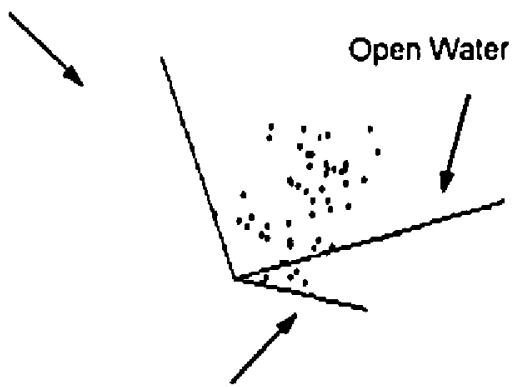

Atmospheric Pressure, Lag $=2$ days (b)

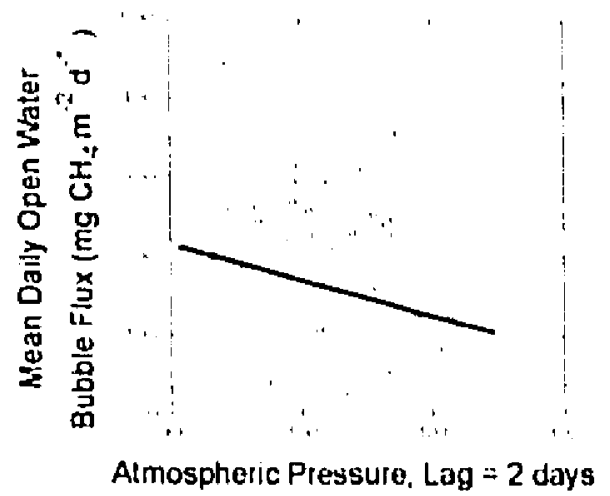

d)

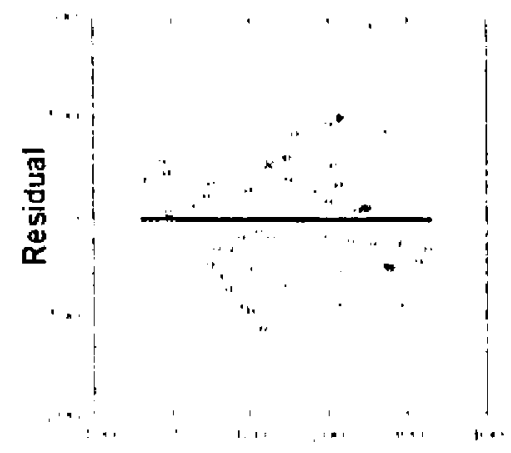

Estimate

Mulliple Limeil Regression Esululion:

Mean Daily Open Waler Bubble Flux $=-448+67.7$ Temp

+36.6 Aliti. Press. Laig 2 disys + 0.45 PAK

$$
r^{2}=0.70 \quad N=51 \quad S E E=6.3
$$$$
F^{*}-.37 .2 \quad p<0.06105
$$

Fig. 3.19: Regression Analysis of Mean Daily Open Water Bubble Fluxes

a) Sediment Temperature at $20 \mathrm{~cm}$ depth

explains $64 \%$ of variance in mean open water bubble fluxes

b) Atmospheric Pressure 2 days prior to measurement

explains a further $4 \%$ of variance; PAR explains a further $4 \%$ (not shown)

c) 3D plot of most significant predictors with flux

d) Distribution of regression residuals is homogeneous 
i)

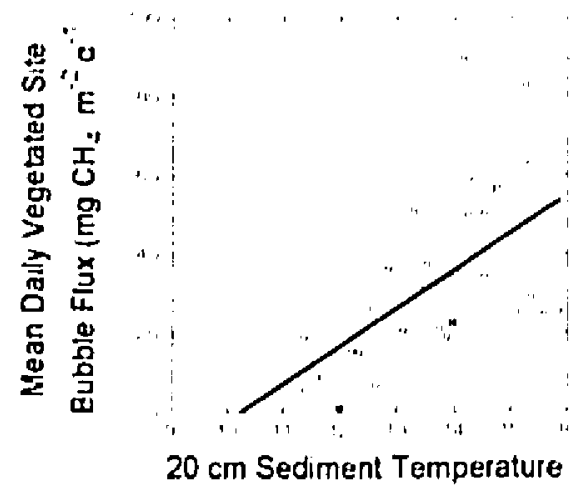

c)

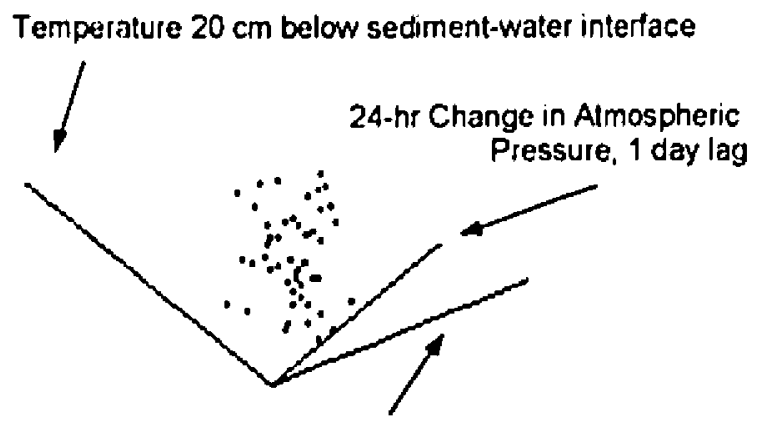

Vegetated Sile Bubble Flux b)

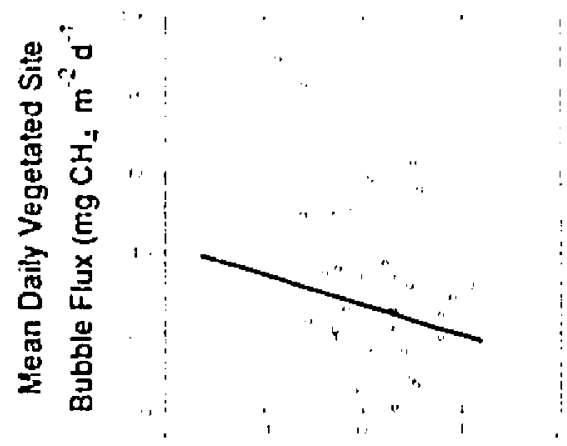

24.hr Change in Atmospheric Pressure, 1 day lag

d)

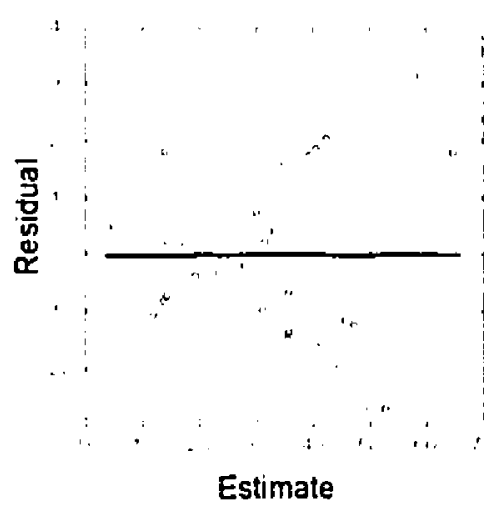

Multiple Lincar Regression Equaltion:

Mean Daily Vegetaled Sile Bubble Flux $=-104.1+10.01$ Temp

- 1.3.5 Change in Alur. Press. Lag I day

$$
\begin{array}{lc}
r^{2}=0.55 & N=51 \quad S E E=14.8 \\
F=29.3 & p<0.00005
\end{array}
$$

Fig. 3,20: Regression Analysis of Mean Daily Vegetated Site Bubble Fluxes

a) Sediment temperature at $20 \mathrm{~cm}$ depth

explains $45 \%$ of variance in mean vegetated site bubble fluxes

b) 24-hr change in atmospheric pressure 1 day prior to measurement explains a further $11 \%$ of variance

c) 3D plot of predictors with flux

d) Distribution of regression residuals is homogeneous 
inventories calculated from dissolved $\mathrm{CH}, \mathrm{l}$ concentrations may he used to indicalle changes in the total pool of $\mathrm{CH}_{4}$ in the sediments of the beaver pond.

Bubble fluxes could not be detected by changes in porewater $\mathrm{Cll}_{4}$ storage. Spearman correlation coeflicients were computed between interpolated $\% 2-4$-hour changes in porewater $\mathrm{CH}_{1}$ storage and bubble fluxes (Table 3.6). Many correlations are negative, indicating that increasing bubble flux is sometimes associated with declining porewater $\mathrm{CH}_{4}$ concentrations. Regression analysis yielded no significant relationship, however, between changes in porewater $\mathrm{CH}_{4}$ storage and changes in bubble flux. Bubble fluxes comprised merely $4-6 \%$ of stored $\mathrm{CH}_{4}$, exceeding $10 \%$ only on three sampling dates. A significant relationship would not be expected since bubbles comprised a small fraction of potential $\mathrm{CH}_{4}$ emissions.

Table 3.6 Spearman Pairwise Corrclation Coefficients (r) Between 24-hour \% Change in Bubble Fluxes and Porewater $\mathrm{CII}_{1}$ Concentrations

\begin{tabular}{|c|c|c|c|c|}
\hline $\begin{array}{c}\text { Relative \% Clange } \\
\text { in Porewater } \mathrm{CH}_{4} \\
\text { concentration }\end{array}$ & $\begin{array}{c}\text { Depth of } \\
\text { Piezometer }\end{array}$ & $\begin{array}{c}\text { Relative \% Change in } \\
\text { Mean Dail. Vegetnted } \\
\text { Sitc Bubble Fluxes }\end{array}$ & $\begin{array}{c}\text { Relative \% Change in } \\
\text { Mean Daily Open Watter } \\
\text { Bubble Fluses }\end{array}$ & $\mathrm{n}$ \\
\hline Shallow & $1.0 \mathrm{~m}$ & 0.36 & -0.41 & 10 \\
Piezometer Nest & $0.7 \mathrm{~m}$ & 0.00 & -0.03 & 10 \\
(approx. water & $0.5 \mathrm{~m}$ & -0.52 & -0.15 & 12 \\
depth $0.2 \mathrm{~m}$ ) & $0.3 \mathrm{~m}$ & -0.25 & 0.35 & 12 \\
& $0.1 \mathrm{~m}$ & 0.06 & 0.05 & 12 \\
\hline Intermediate & $1.0 \mathrm{~m}$ & -0.21 & -0.46 & 10 \\
Piezometer Nest & $0.7 \mathrm{~m}$ & -0.41 & -0.27 & 10 \\
(approx. water & $0.5 \mathrm{~m}$ & -0.32 & 0.22 & 12 \\
depth $1.0 \mathrm{~m}$ ) & $0.3 \mathrm{~m}$ & -0.22 & 0.19 & 12 \\
& $0.1 \mathrm{~m}$ & -0.04 & -0.20 & 12 \\
\hline Deep & $1.0 \mathrm{~m}$ & 0.00 & -0.83 & 8 \\
Piezometer Nest & $0.7 \mathrm{~m}$ & 0.26 & -0.21 & 10 \\
(approx. water & $0.5 \mathrm{~m}$ & -0.55 & 0.06 & 11 \\
depth $1.7 \mathrm{~m}$ ) & $0.3 \mathrm{~m}$ & -0.47 & 0.06 & 11 \\
& $0.1 \mathrm{~m}$ & -0.08 & 0.08 & 11 \\
\hline
\end{tabular}




\subsection{Ciross l3ubble Storage and Production}

Estimates of bubble (:It, reservoirs were obtained on Aug. 27, 1994 (J.d. 239) by prodding sediments to a depth of approximately $I \mathrm{~m}$, at two previously undisturbed boardwalk siles, until no more bubbles were observed. At a site vegetated with grasses by the pond margin, $5.4 \mathrm{~g} \mathrm{CH}_{4} \mathrm{~m}^{-2}$ was collected, while $7.1 \mathrm{~g} \mathrm{CH}_{4} \mathrm{~m}^{-2}$ was collected at a non-vegetated deep water $(1.4 \mathrm{~m})$ site. The pord margin released numerous small bubbles, while the deeper site released fewer, but much larger bubbles. Bubble volumes were $15.6 \mathrm{~L} \mathrm{~m}^{-2}$ at the vegetated site, and $16.5 \mathrm{~L} \mathrm{~m}^{-2}$ at the open water site. To my knowledge, these are the largest bubble storage volumes recorded (see Chanton and Dacey, 1991).

The funnels were kept in situ and witlin two weeks (to J.d. 253) the vegetated site had emitted a further $0.8 \mathrm{~g} \mathrm{CH}_{4} \mathrm{~m}^{-2}$, and the open water site had emitted $0.11 \mathrm{~g}$ $\mathrm{CI}_{4} \mathrm{~m}^{-2}$. Further prodding yielded $4.8 \mathrm{~g} \mathrm{CH}_{4} \mathrm{~m}^{-2}$ produced at the margin, and $0.8 \mathrm{~g}$ $\mathrm{CH}_{4} \mathrm{~m}^{-2}$ produced at the deep water site. Total production, calculated as the sum of all bubbles produced since the sites had been initially prodded, was $399 \mathrm{mg} \mathrm{CH}_{4} \mathrm{~m}^{-2} \mathrm{~d}^{-1}$ at the vegetated site, and $68 \mathrm{mg} \mathrm{CH}_{4} \mathrm{~m}^{-2} \mathrm{~d}^{-1}$ at the open water site.

\subsubsection{Isotopic Analysis of Bubble Cll}

$\mathrm{CII}_{4}$ in bubbles (Fig. 3.21) from vegetated sites was significantly heavier in carbon $(C)\left(\delta^{1.3} \mathrm{C}=-55.8 \pm 1.8 \%, n=17\right)(t=4.78, p<0.05)$ and significantly lighter in hydrogen $(H)(\delta D($ deuterium $)=-378.1 \pm 15.6 \%, n=17)(t=-2.43, p<0.05)$ than bubbles from open water sites $\left(\delta^{13} \mathrm{C}=-59.6 \pm .2 .6 \% ; \delta D=-362.9 \pm 18.7 \%, \mathrm{n}=13\right)$. 


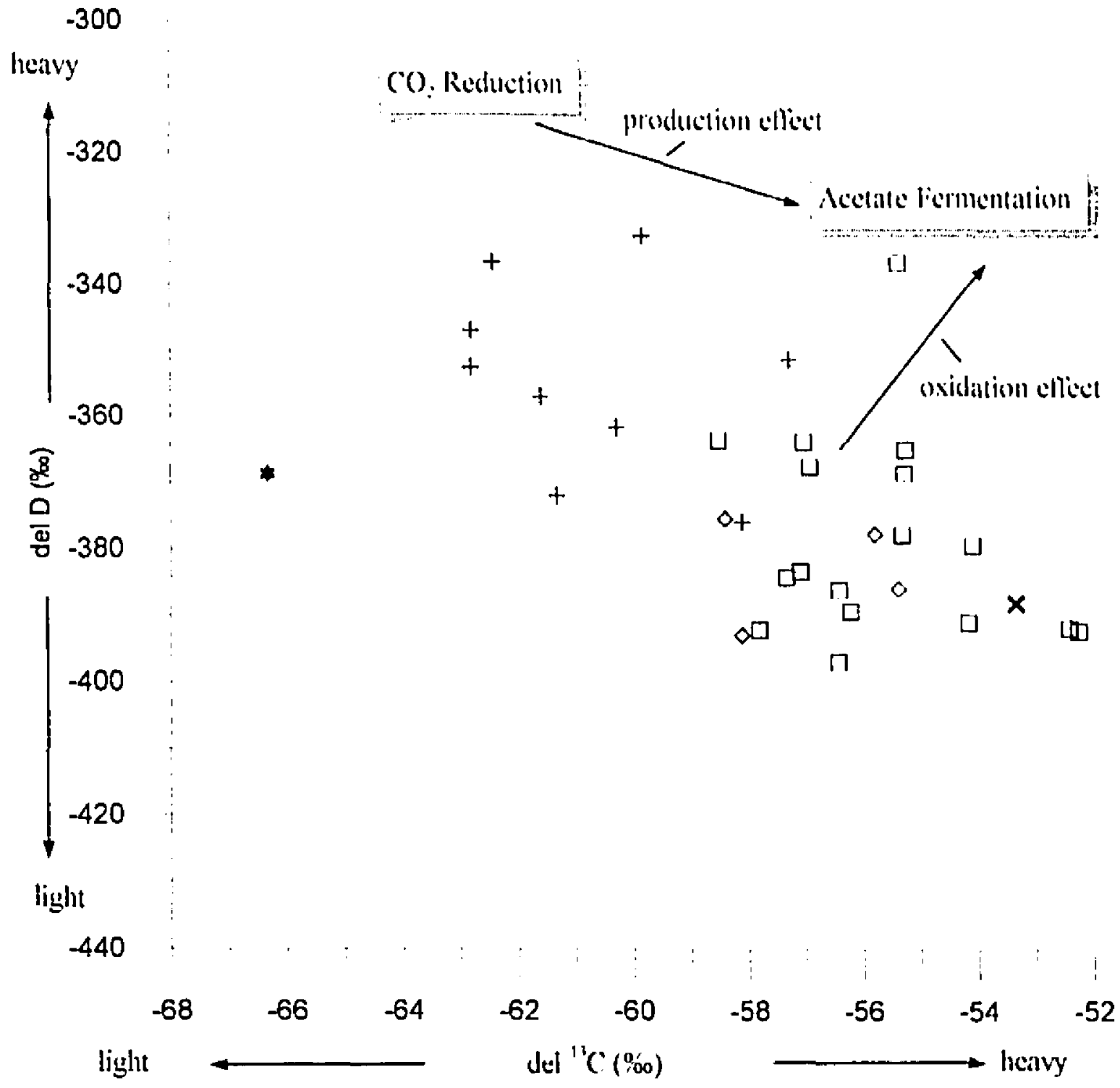

Naturally-released Bubbles:

+ Open Water

$\square$ Vegetated

$\diamond \quad$ Channels in Vegetation

$-\quad \operatorname{del} \mathrm{D}--590.8-3.8 \mathrm{del}{ }^{13} \mathrm{C} \quad \mathrm{I}^{2}-0.33 \mathrm{~F}-1.3 .9 \mathrm{p}-0.001$

Fig. 3.21: Isotopic Composition of C.H in Bubbles with line of best fit for naturally released bubbles, and slopes for production (Whiticar et al., 1986) and oxidation (Coleman et al., 1981) effects 
Regression analysis of the isotopic composition of all naturally-released bubbles yielded the equation:

$$
\delta \mathrm{D}(\%)=-590.8-3.8 \delta^{1.3} \mathrm{C}(\%) \quad \mathrm{r}^{2}=0.33 \quad \mathrm{p}<0.05
$$

Bubbles obtained by prodding were similar to naturally-released bubbles at a vegetated site, but isotopically lighter compared to naturally-released bubbles at an open water site (Fig. 3.21).

Bubbles collected from open water sites along the beam transect (which comprised small channels between the vegetation) were intermediate in composition, compared to bubbles from open water sites along the line transect and bubbles from all vegetated sites (Fig. 3.21). The isotopic signature of bubbles from these channels was more simila:, however, te bubbles from vegetated sites $\left(\delta \mathrm{D}: \mathrm{t}=0.59, \mathrm{p}>0.05 ; \delta^{13} \mathrm{C}\right.$ : $t=1.21, p>0.05)$ than those from open water sites $\left(\delta D: t=4.60, p<0.005 ; \delta^{13} C: t=-3.32\right.$, $p<0.01)$.

These results indicate differences in isotopic composition between open water and vegetated sites which are likely due to a difference in production processes. If the differences were due to greater oxidation at vegetated sites, one would expect $\mathrm{CH}_{4}$ in bubbles emitted from vegetated sites to be isotopically heavier in both carbon and hydrogen compared to open water sites. $\mathrm{CH}_{4}$ oxidizers preferentially consume the lighter isotopes of $\mathrm{C}$ and $\mathrm{H}$ (Coleman et al., 1981; see direction of oxidation effect line shown in Fig. 3.21). Huwever, the slope of the regression line through the isotope data in Fig. 3.21 is similar to a slope determined by Whiticar et al. (1986), expressing differences created by different production pathways. This indicates that different 
substrates are used by methanogens between vegetated and open water sites. Al open water sites, $\mathrm{CO}_{2}$ is the dominant substrate for $\mathrm{C}_{4}$ production while in vegelated sites, $\mathrm{CH}_{4}$ is produced by acetate reduction.

\subsection{Sediment-Water Fluxes}

Between June 25 through August 20 (J.d. 176 - 232), 39 fluxes of Cll across the sediment-water interface were measured using benthic chambers. No fluxes were obtained over emergent macrophytes, although some chambers contained submergent macrophytes. All sites are, therefore, analogous to chamber and bubble flux open water sites. There was no significant difference between fluxes over submergent macrophytes and those with no vegetation $(t=0.80, p>0.05)$.

Some difficulties arose while using the benthic chambers. 'The chambers had to be held in place on the pond bottom and some disturbance resulted. $\mathrm{CH}, \mathrm{w}$ would also continue to accumulate in the chambers between sampling (despite venting) so that the chambers had to be removed and replaced, exacerbating the disturbance. It is not known if the measurements reflect diffusive fluxes or disturbance of the sediments causing high but linear $\mathrm{CH}_{4}$ emissions.

Two sediment-water fluxes, measured near the pond margin (1923.1 $\pm 476 \mathrm{mg}$ $\mathrm{CH}_{4} \mathrm{~m}^{-2} \mathrm{~d}^{-1}$ ), were much greater than fluxes obtained elsewhere along the boardwalk (183.9 $\pm 112 \mathrm{mg} \mathrm{CH}_{4} \mathrm{~m}^{-2} \mathrm{~d}^{-1}$ ). Because the reasons for this difference are not understood and because this difference was so pronounced, the fluxes obtained from the pond margin were not included in subsequent analyses. 
Sediment-water (benthic) chamber and water-air (lloating) chamber fluxes were rarely measured on the same day, so comparisons (Fig. 3.22) were made using all data for the period from June 25 through August 20. Fluxes across the sediment-water interface $\left(183.9 \pm 112 \mathrm{mg} \mathrm{CH}_{4} \mathrm{~m}^{-2} \mathrm{~d}^{-1}\right)$ were significantly greater $(U=31, p<0.005)$ than fluxes across the water-air interface from ('arex sites $\left(96.3 \pm 80 \mathrm{mg} \mathrm{CH}_{4} \mathrm{~m}^{-2} \mathrm{~d}^{-1}\right)$. The sediment-water fluxes were higher but not significantly greater $(U=64, p>0.05)$ than clamber fluxes from open water sites $\left(138.6 \pm 154 \mathrm{mg} \mathrm{CH}_{4} \mathrm{~m}^{-2} \mathrm{~d}^{-1}\right)$.

\subsubsection{Sediment and Water Column $\mathrm{CH}_{4}$ Oxidation}

$\therefore \quad$ The observed difference between mean daily sediment-water fluxes $(183.9 \mathrm{mg}$ $\left.\mathrm{CH}_{4} \mathrm{~m}^{-2} \mathrm{~d}^{-1}\right)$ and mean daily open water-air fluxes (138.6 $\mathrm{mg} \mathrm{CH}_{4} \mathrm{~m}^{-2} \mathrm{~d}^{-1}$ ) may be due to oxidation in the water column. By difference, the average amount of $\mathrm{CH}_{4}$ oxidation is $45.3 \mathrm{mg} \mathrm{CH}_{4} \mathrm{~m}^{-2} \mathrm{~d}^{-1}$, for this time interval.

Sediment-water flux measurements using methyl fluoride (MF) to inhibit $\mathrm{CH}_{4}$ oxidation yielded mean fluxes of $353.5 \pm 236$ and $435 \pm 788 \mathrm{mg} \mathrm{CH}_{4} \mathrm{~m}^{-2} \mathrm{~d}^{-1}$, on July 1 (J.d. 192) and July 15 (J.d. 196), respectively (Fig. 3.22). The differences between these fluxes and the sediment-water diffusive fluxes without MF on the same dates were 95 and $271 \mathrm{mg} \mathrm{CH}_{4} \mathrm{~m}^{-2} \mathrm{~d}^{-1}$. These differences may represent oxidation in the upper layers of the sediments and the bottom $25 \mathrm{~cm}$ of the water column, but the standard deviations associated with the measured MF-inhibited fluxes are greater than the differences attributed to oxidation so the data should be interpreted with a great deal of caution. 


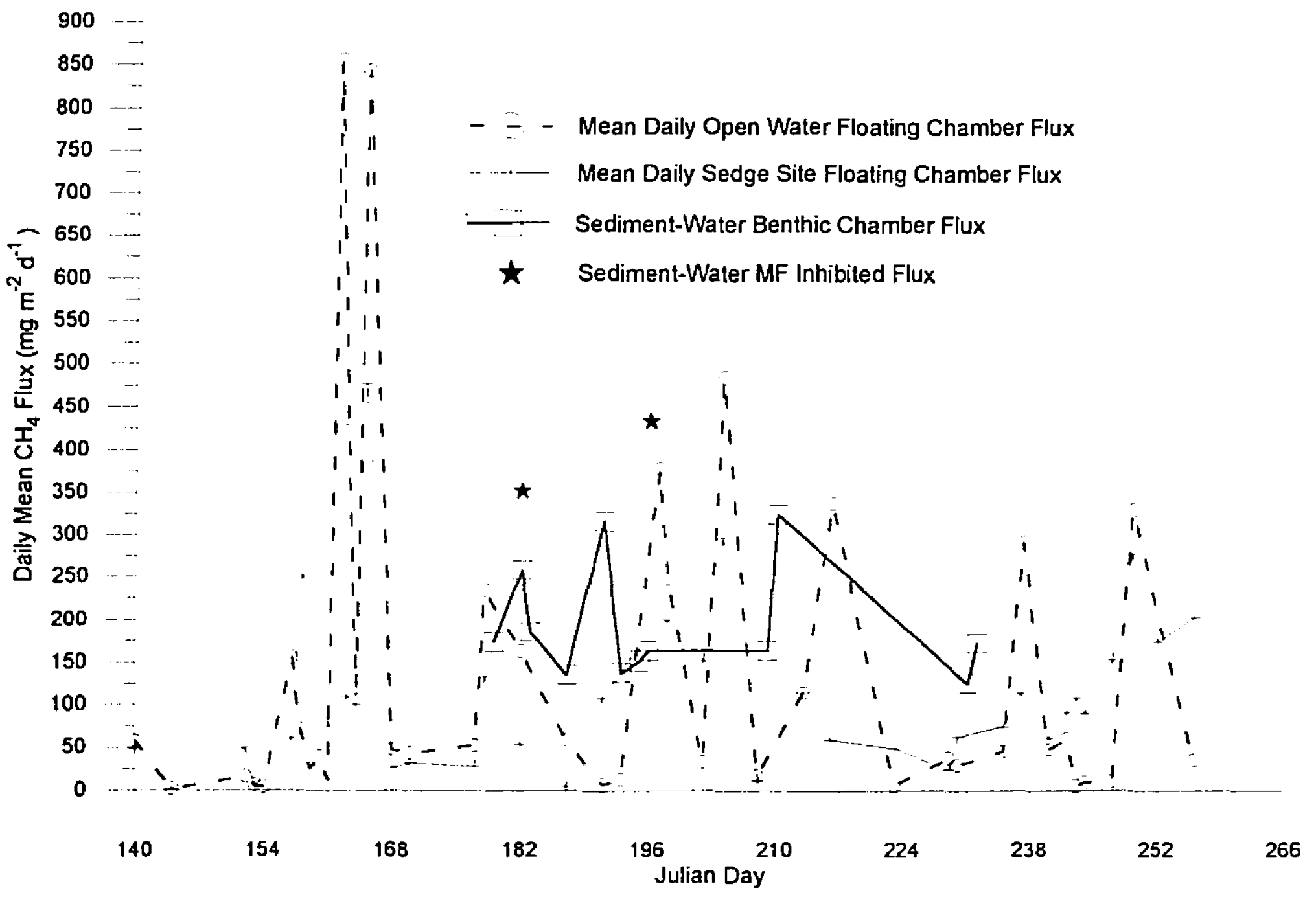

Fig 3.22: Comparison of Water-Air and Sediment-Water $\mathrm{CH}_{\text {, Fluxes }}$ 


\subsection{Sediment-Water Interface CIL Profiles}

Ten profiles of $\mathrm{CH}_{4}$ concentrations in the sediments were obtained from June 23 to September 11 (J.d. 174 - J.d. 254) (Fig. 3.23). Generally, the protiles showed lowest $\mathrm{CH}_{4}$ concentrations in the water column, rapidly increasing concentrations across and below the sediment-water interface, and greatest $\mathrm{CH}_{4}$ concentrations at depth. Only 2 profiles (Fig. 3.23a and f) showed significant decreases in $\mathrm{CH}_{4}$ at depth. The profile from a floating mat (Fig 3.5. Ih) showed a decrease in $\mathrm{CH}_{4}$ at depth because the peeper penetrated the mat and measured $\mathrm{CH}_{4}$ in the water column beneath it.

$\mathrm{CH}_{4}$ concentrations were generally lower in the profiles from shallow water sites (range 0.9 to $1.7 \% \mathrm{CH}_{4}$ ) than from deeper sites (range 1.7 to $2.5 \% \mathrm{CH}_{4}$ ). The layer below the sediment water interface, in which the concentrations of $\mathrm{CH}_{4}$ increased steeply, was also thicker ( 9 to $16 \mathrm{~cm}$ ) for shallow water sites (Fig. $3.23 \mathrm{~b}$,c,f and h) than for deep-water sites ( 3 to $9 \mathrm{~cm}$ ) (Fig. 3.23 a,d,e and g). Oxidation may be partially responsible for these steep gradients, therefore the oxidation zone may penetrate deeper in shallow water sediments. It is important to note, however, that an algal layer was observed even at the deepest site (Fig. 3.23d), indicating that most areas of the pond receive enough light to support algal populations and may therefore also support populations of methanotrophs.

Fluxes of $\mathrm{CH}_{4}$ from the sediments were modelled using a Fickian diffusion model, an estimate of porosity (0.8), and the $\mathrm{CH}_{4}$ gradient between the depth of naximum $\mathrm{CH}_{4}$ concentration and the sediment water interface (Table 3.7). These fluxes are shown in Fig. 3.24 for comparison with average daily water-air diffusive 

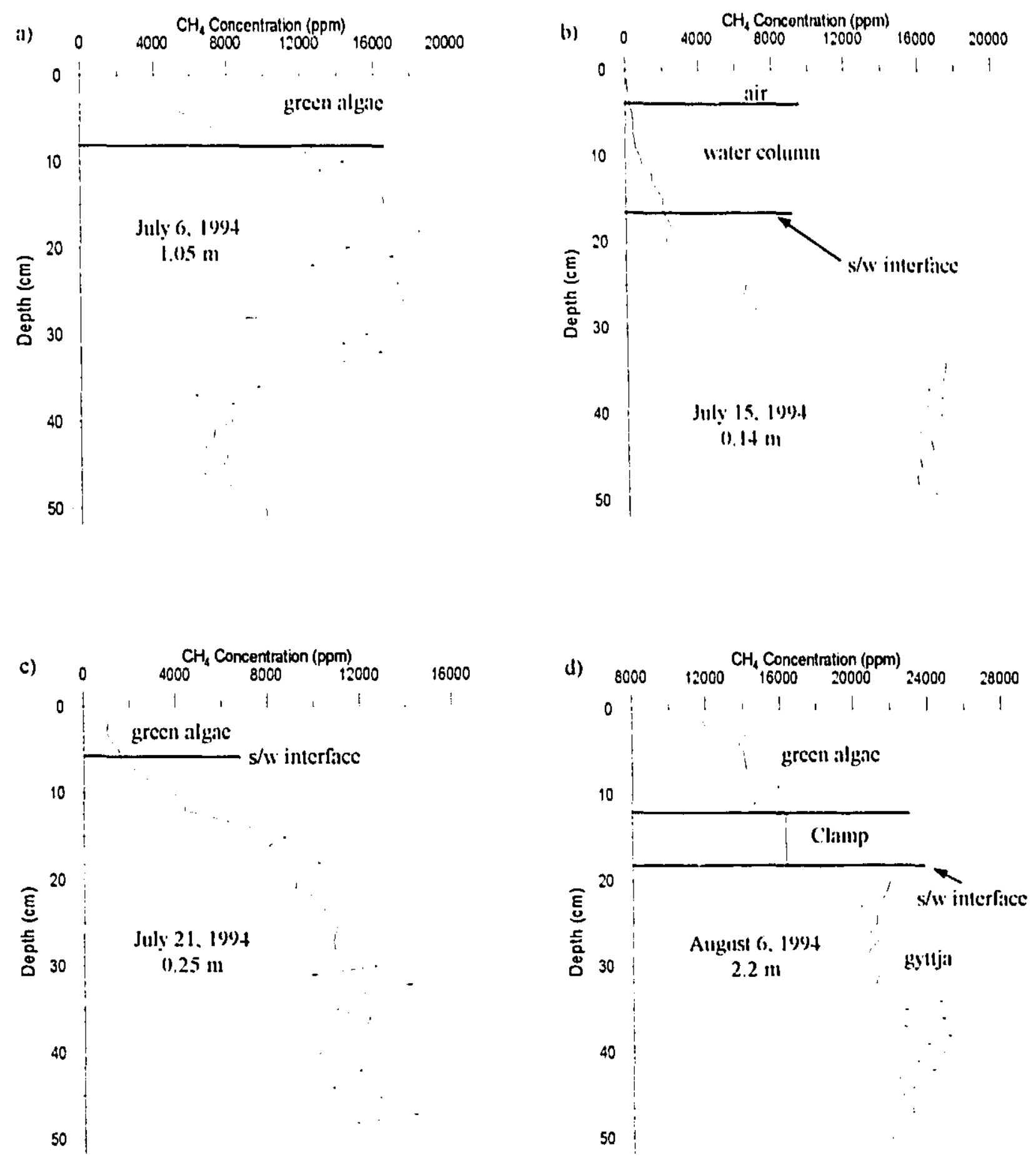

Fig. 3. 23: Peeper Porewater $\mathrm{CH}_{\text {, Profiles }}$ with mid-date between peeper placement and removal, depth of water at site, and characteristics observed on peeper after removal 

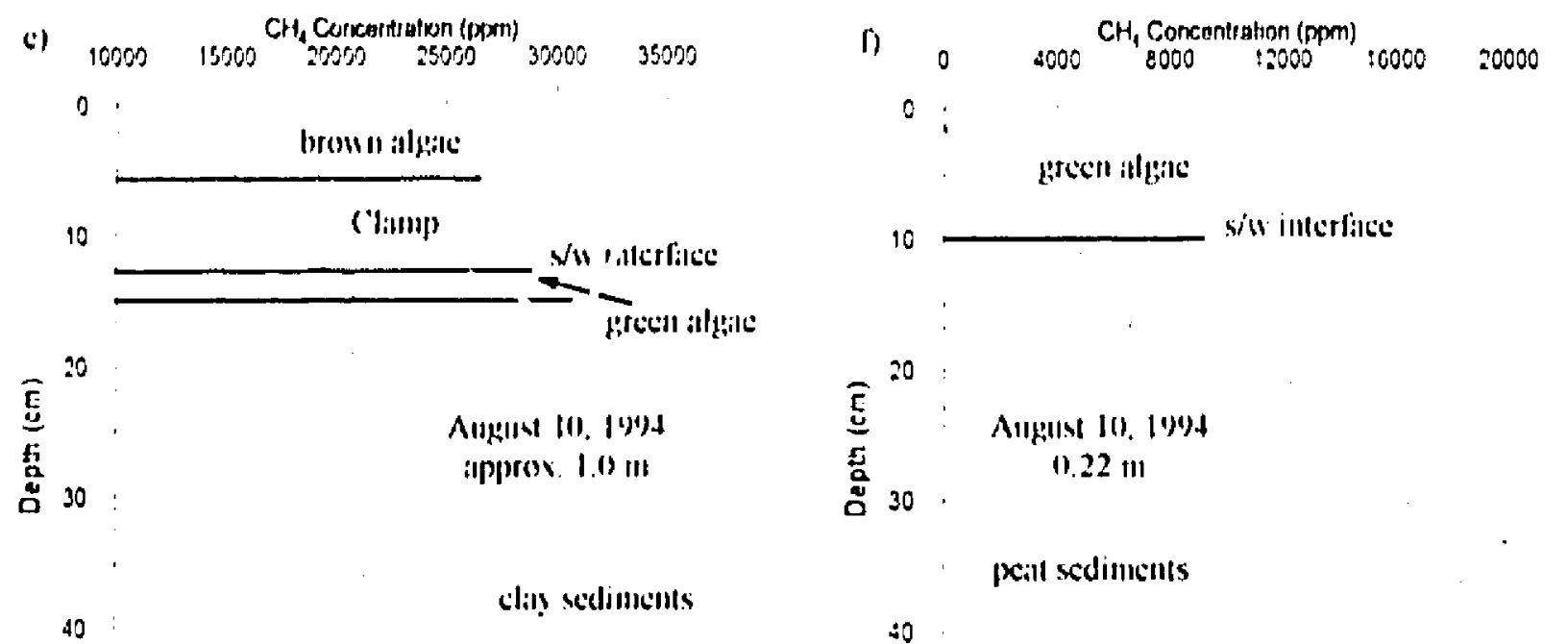

30

so

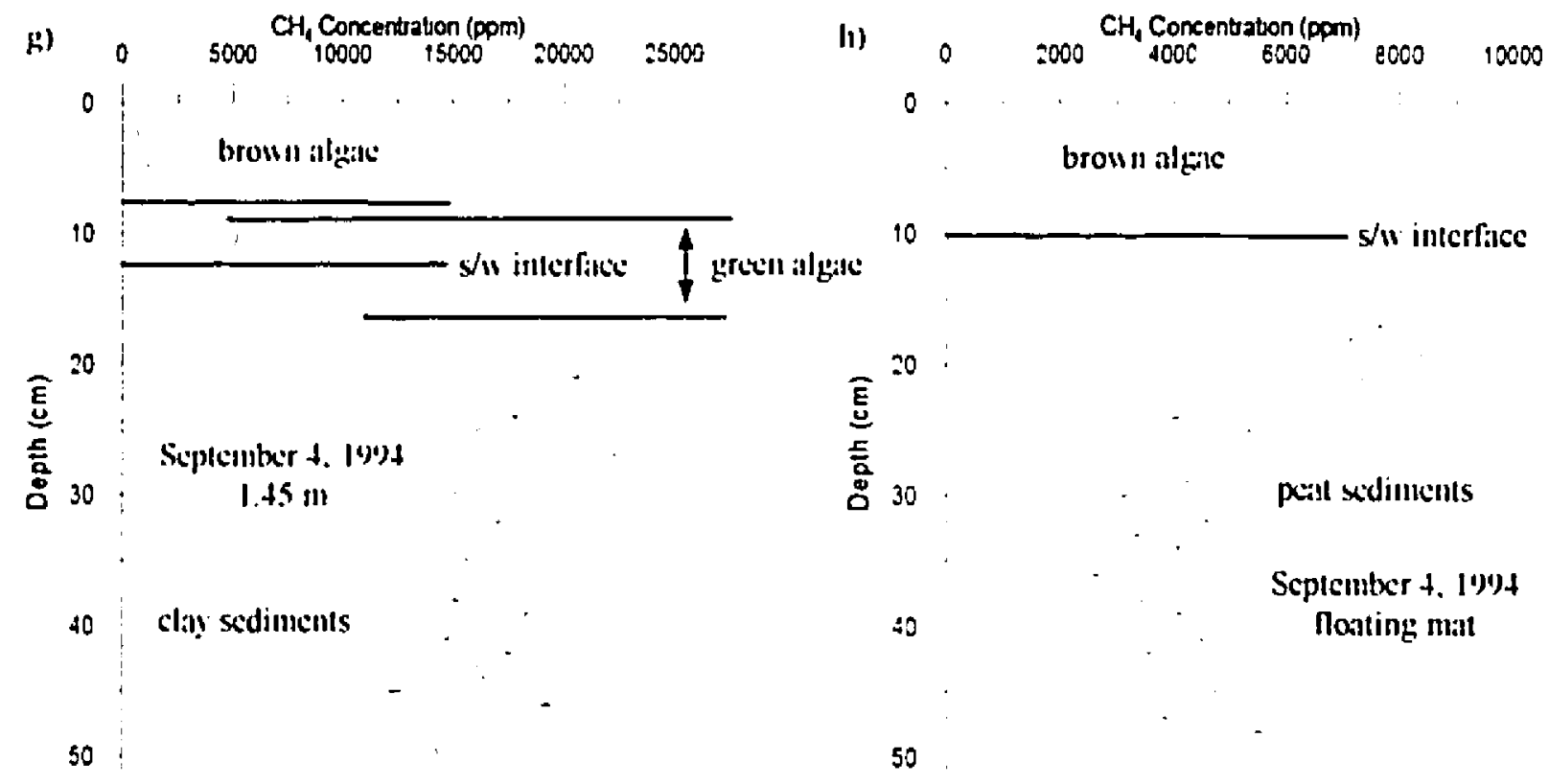

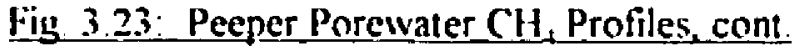




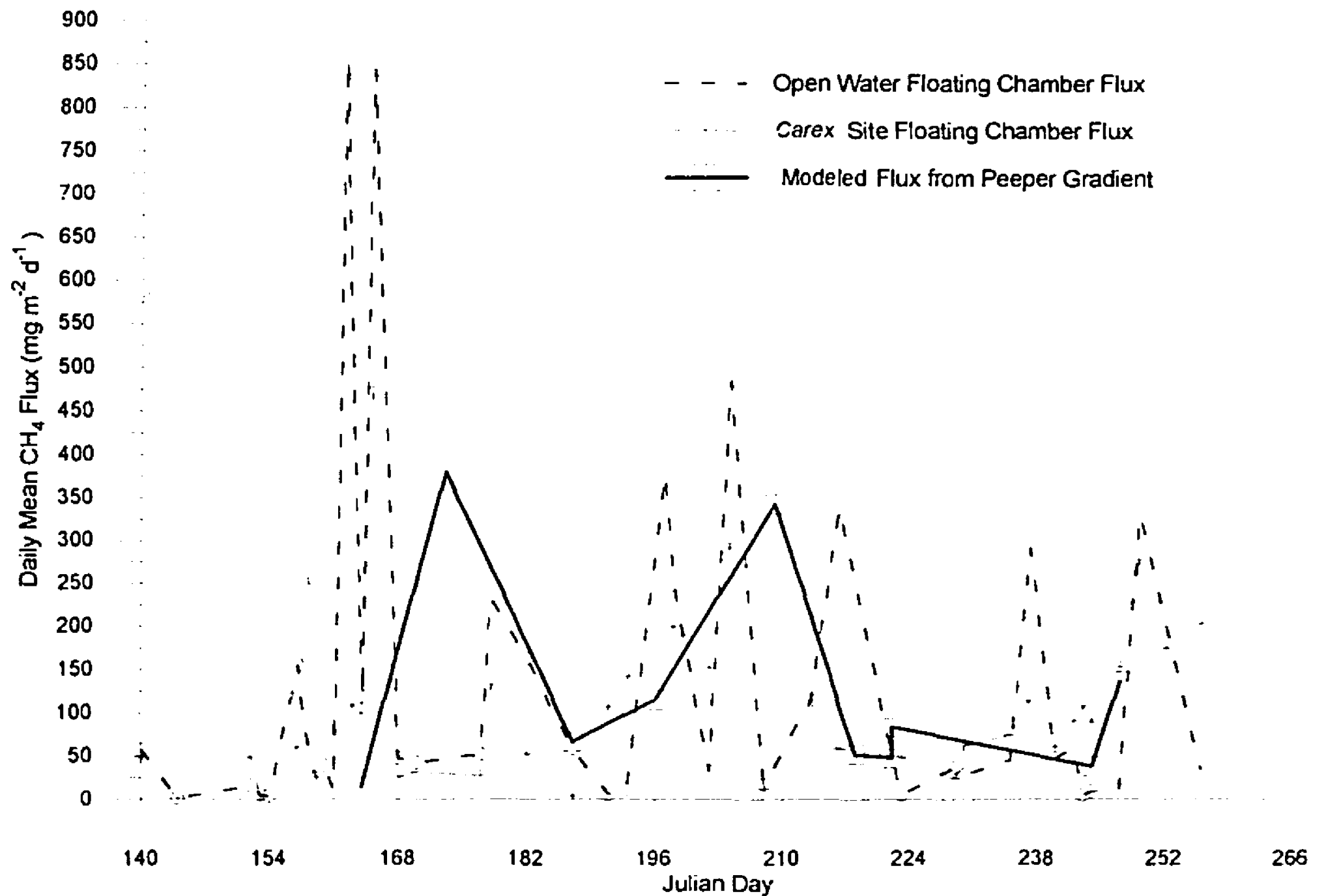

Fig. 3.24 Modeled Sediment-Water Diffusive CH: Fluxes from Peeper Profiles and Neasured Water-Air Fluxes from Floating Chambers 
fluxes. The trends are similar, but the modelled sedimemt-water fluxes are neither consistenly greater nor smaller than the measured mean daily open water-air (floating chamber) lluxes.

Table 37 lickian Sediment-Water Diffusive Fluxes Modelled from Peeper Profiles

\begin{tabular}{|l|c|c|}
\hline Ditte & Depth of Water (m) & Modelled Flux \\
\hline June 13 (J.d. 164) & 0.7 & 15.2 \\
June 22 (J.d. 173) & 1.1 & 380.4 \\
July 6 (J.d.187) & 1.05 & 07.0 \\
July 1.5 (J.d. 196) & 0.14 & 115.3 \\
July 21 (J.d. 209) & 0.25 & 343.2 \\
Aug. 6 (J.d. 218) & 2.2 & 52.4 \\
Aug. 10 (J.d. 222: & 1.0 & 48.2 \\
Aug. 10 (J.d. 222) & 0.22 & 83.8 \\
Sept.1 (J.d. 244) & 1.45 & 136.3 \\
Sept 4 (J.d. 247) & 0.02 (lloating mat) & 38.5 \\
\hline
\end{tabular}

- mid-date between peeper placement and removal

\subsection{Water Column CIL, Profiles}

From June 3 through Sepiember II ( J.d. 154 - J.d. 254), a total of 20 profiles of $\mathrm{Cll}$, concentrations in the water column (Fig. 3.25) were obtained from 3 different sites in the beaver pond. The majority of these (e.g. Fig. $3.25 \mathrm{~d}-\mathrm{i})$ were taken from the tower platform at the end of the boardwalk, adjacent to the pond level gauge. The first three water profiles shown (Fig. 3.25 a-c), and two others taken in July (not shown), were sampled from shallower sites.

Most profiles were stratified, with the highest concentrations of $\mathrm{CH}_{4}$ close to the sediment-water interface, and steeply declining concentrations in the bottom 10 to 

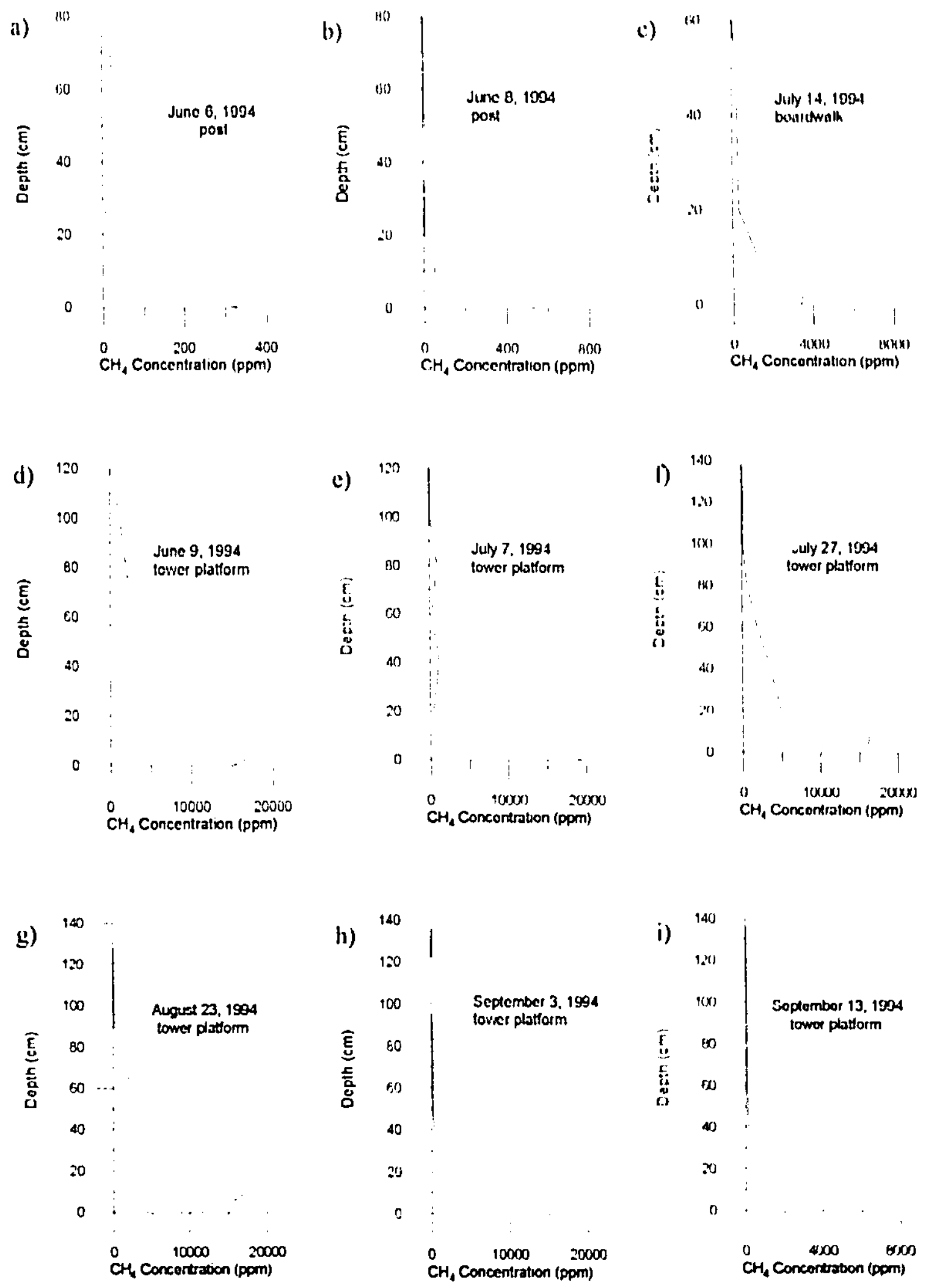

Fig. 3.25 Water Column $\mathrm{CH}_{4}$ Profiles 
$20 \mathrm{~cm}$. Shallow water sites had lower (' $11_{1}$ coneentrations at the sediment-water interface $(12.59+1.302 \mathrm{ppm})$ than the decper plation site $(1.5218 \pm 4806 \mathrm{ppm})$. The sediment-water interface $(\%$, concentrations were often greater than those observed in the peeper profiles (see lïig.s 3.23 and 3.25). The peeper profiles and water column profiles were never taken at the same sites, however, and these differences illustrate the high spatial variability in $\mathrm{CH}_{4}$ concentrations observed in the beaver pond.

Bottom-water $\mathrm{CH}_{4}$ concentrations were fairly consistent at the platform site from June 9 through Sept. 3 (J.d. 160 - J.d. 246) (16399 $\$ 3948$ ppm), but decreased in mid-September (J.d.252 - 256) $(7539 \pm 510 \mathrm{ppm})$. This is consistent with the decrease in porewater $\mathrm{CH}_{4}$ observed at the same time (see Section 3.7).

\subsubsection{Isotopic Composition of $\mathrm{CH}_{4}$ in the Water Column}

Two samples of $\mathrm{CH}_{4}$ from a profile at the tower platform were analysed for $\mathrm{H}$ and $\mathrm{C}$ isotopes (see Fig 3.28). $\mathrm{CH}_{4}$ from the sediment-water interface was lighter both in $\mathrm{C}\left(\delta^{1.3} \mathrm{C}=-63.8 \%\right)$ and $\mathrm{H}(\delta \mathrm{D}=-365.2 \%)$ than $\mathrm{CH}_{4}$ in water $6 \mathrm{~cm}$ above the interface $\left(\delta^{1.3} \mathrm{C}=-62.3 \% ; \delta \mathrm{D}=-363.1 \%\right)$. This difference is not significant, but is consistent with a change due to oxidation as $\mathrm{CH}_{4}$ diffuses upwards in the water columin. 


\subsection{Porewilter (.11, from Piczometers}

From June 2 (J.d. 15.4) through Sept. 10 (J.d. 25.3) (11, dissolved in porewaters was measured from 15 piezometers in 3 nests. Porewater $\mathrm{CH}_{4}$ concentrations (Fig. 3.26) were initially low, dramatically increased from June 1.3 to July I (J.d. $164-182$ ), then remained consistently high through the season. On the final sampling date, however, $\mathrm{CH}_{4}$ concentrations decreased by up to $50 \%$ since the previous day. There was no consistent trend in concentration with depth between the three sites, but $\mathrm{CH}_{4}$ concentrations were lowest near the sediment surfice al the shallow, vegetated site, while highest concentrations were observed near the surface at the open water sites.

Porewater storage of dissolved $\mathrm{CH}_{4}$ was calculated using profiles of $\mathrm{CH}_{4} \mathrm{fiom}$ piezometers, assuming a porosity of 0.8 , and a profile depth of $1.5 \mathrm{~m}$ (Fig. 3.27) The reservoirs were large, containing up to $30 \mathrm{~g} \mathrm{CH}_{4} \mathrm{~m}^{-2}$ in early July. The reservoirs were similar between sites, although the piezometer nest at the deep site penetrated clay at 0.7 and $1.0 \mathrm{~m}$ and therefore contained less $\mathrm{CII}_{4}$. The dissolved $\mathrm{CII}_{4}$ reservoir was very small in the spring, but was still fairly large at the end of the field season.

\subsubsection{Isotopic Composition of Porewater $\mathrm{Cl}_{4}$}

Samples of porewaters from the 3 piezometer nests were analysed for isotopic composition (Fig. 3.28). Regression analysis of these samples yielded the equation:
$\delta \mathrm{D}(\%)=-454.6-1.9 \delta^{13} \mathrm{C}(\%)$
$r^{2}-0.14$
$p-0.20$
$\mathrm{n}-12$ 
a) 20000

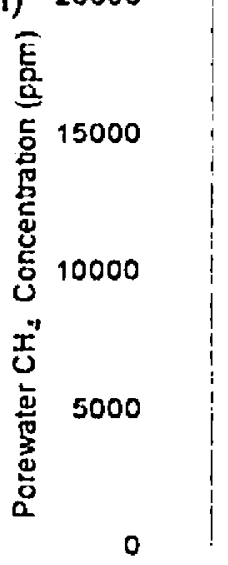

b)

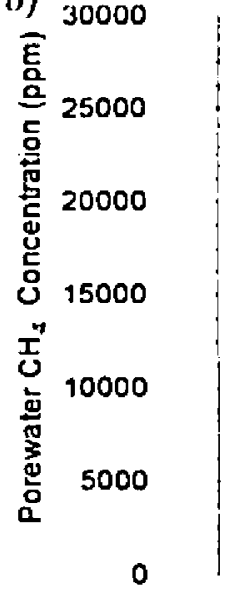

c)

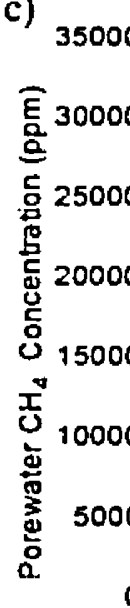

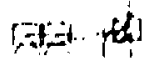
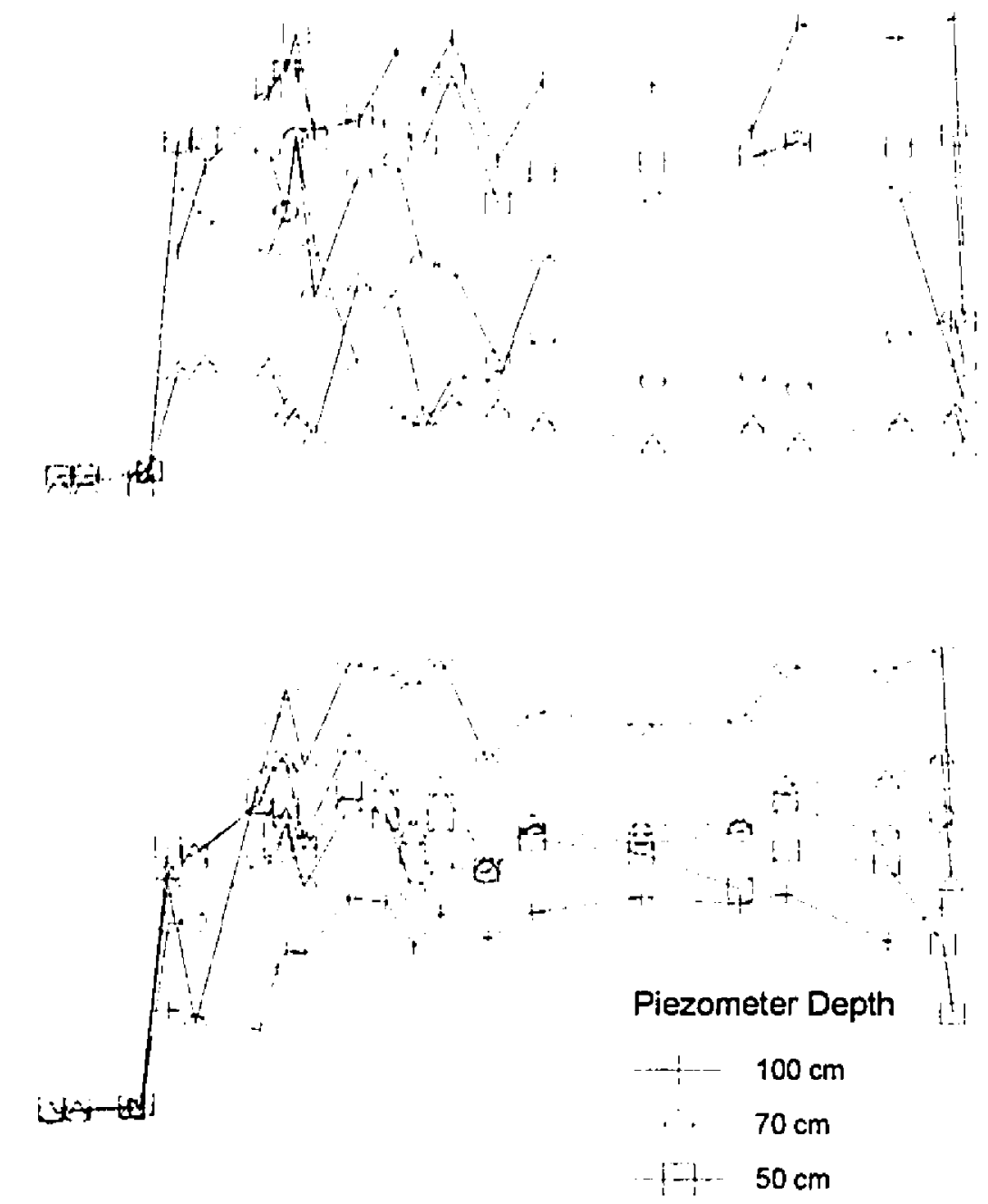

$\therefore \quad 30 \mathrm{~cm}$

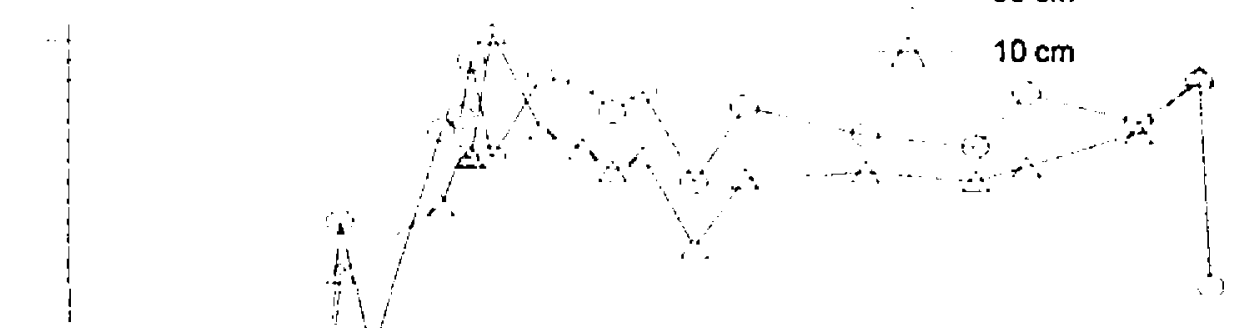

$\therefore \quad 10 \mathrm{~cm}$ 


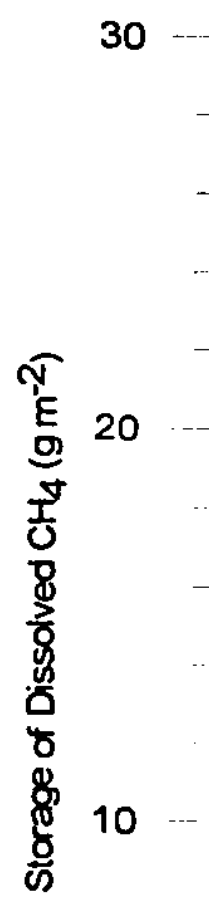

Piezometer Nest (depth of water):

intermediate $(0.5-0.7 \mathrm{~m})$

shallow $(0.4-0.2 \mathrm{~m})$

$\operatorname{deep}(2.2-2.0 \mathrm{~m})$

0

140

154

168

182

196

210

224

238

252

266

Fig. 3.27: Storage of $\mathrm{CH}_{1}$. Dissolved in Porewater (integrated to a depth of $1.5 \mathrm{~m}$ in sediments) 


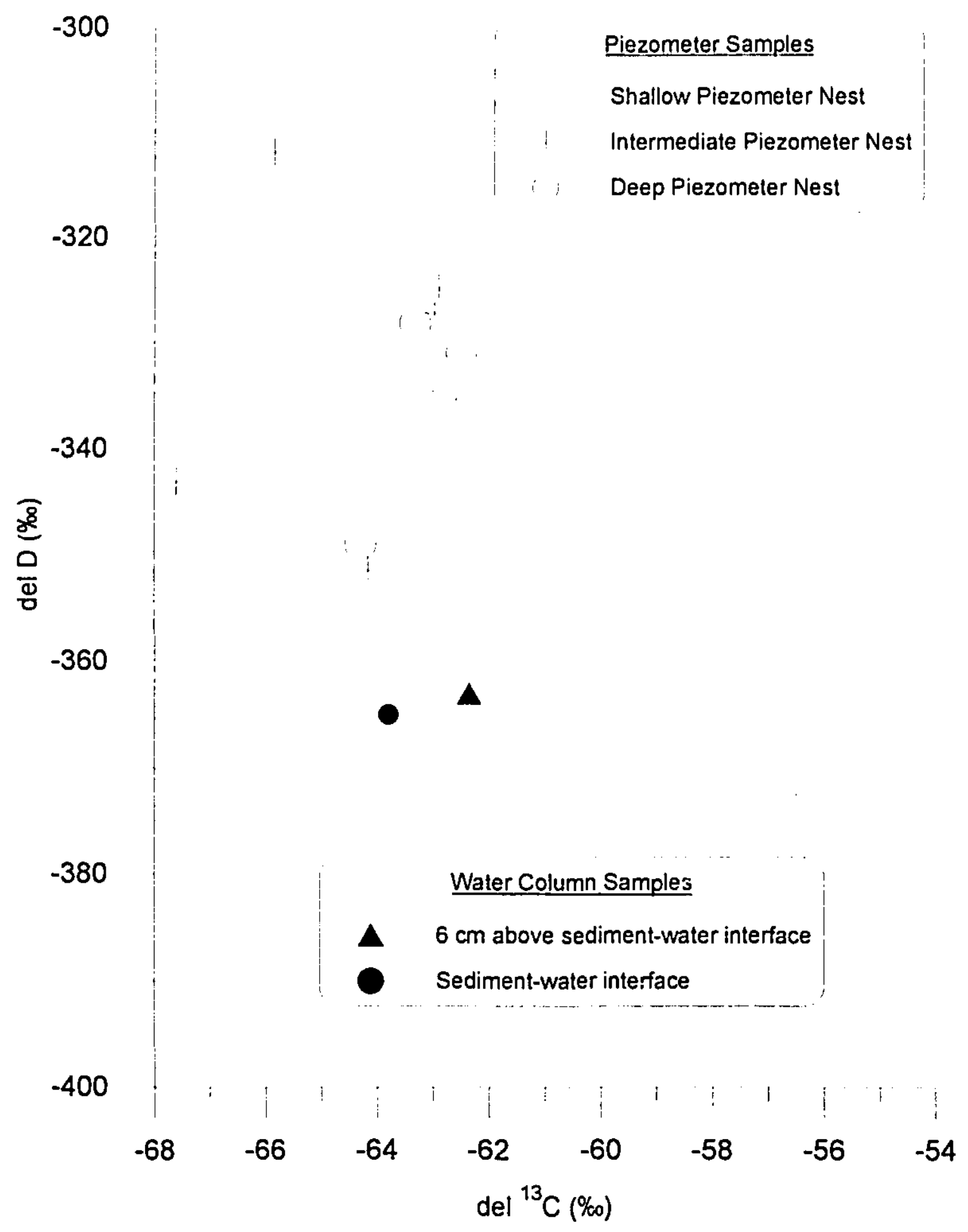

Fig 3.28 Isotopic Composition of Porewater $\mathrm{CH}_{4}$ with Line of Best Fit, and Isotopic Composition of $\mathrm{CH}_{3}$ in the Water Column 
There was no consistent trend in isotopic composition with porewaler depth, either within a nest or between nests. The compositions of $\mathrm{Cl}_{4}$ were similar hetween nests, although $C$ was signilicantly lighter $(U=25, p<0.05)$ in the intermediate nest $\left(\delta^{1.3} \mathrm{C}=-64.7 \pm 2 \%\right)$ compared to the shallow nest $\left(\delta^{1.3} \mathrm{C}=-.59 .6 \pm 3 \%\right)$

\subsection{Laboratory Incubations}

Incubations of pond sediments in the laboratory showed ditlerences in the capacity of vegetated and open water sites to produce and consume $\mathrm{CH}_{4}(\mathrm{Fi}$. 3.29) and Table 3.8; note that more negative values indicate higher consumption rates).

Production potentials, determined under anaerobic conditions, spanned 3 orders of magnitude, and were much greater in sediments from a floating mat than from open water sites. Consumption potentials, determined under aerobic conditions, spanned 2 orders of magnitude, and were also greatest in the floating mat core. Consumption rates were almost invariably greater than production rates. Both production and consumption were greater in a core from a deep open water site where high bubble fluxes were observed (core 2), compared to a core obtained from an open water site adjacent to the boardwalk (core 3 ).

$\mathrm{CH}_{4}$ production was greatest at or near the sediment-water interface (Fig. 3.29a). In the floating mat, production was greatest at the surface, and decreased with depth. The cores from open water sites had maximum $\mathrm{CH}_{4}$ production potentials at depths of 5 to $10 \mathrm{~cm}$ below the sediment-water interface, below which production decreased. Consumption potentials were highest in surface sediments (Fig. 3.29b). 
a)

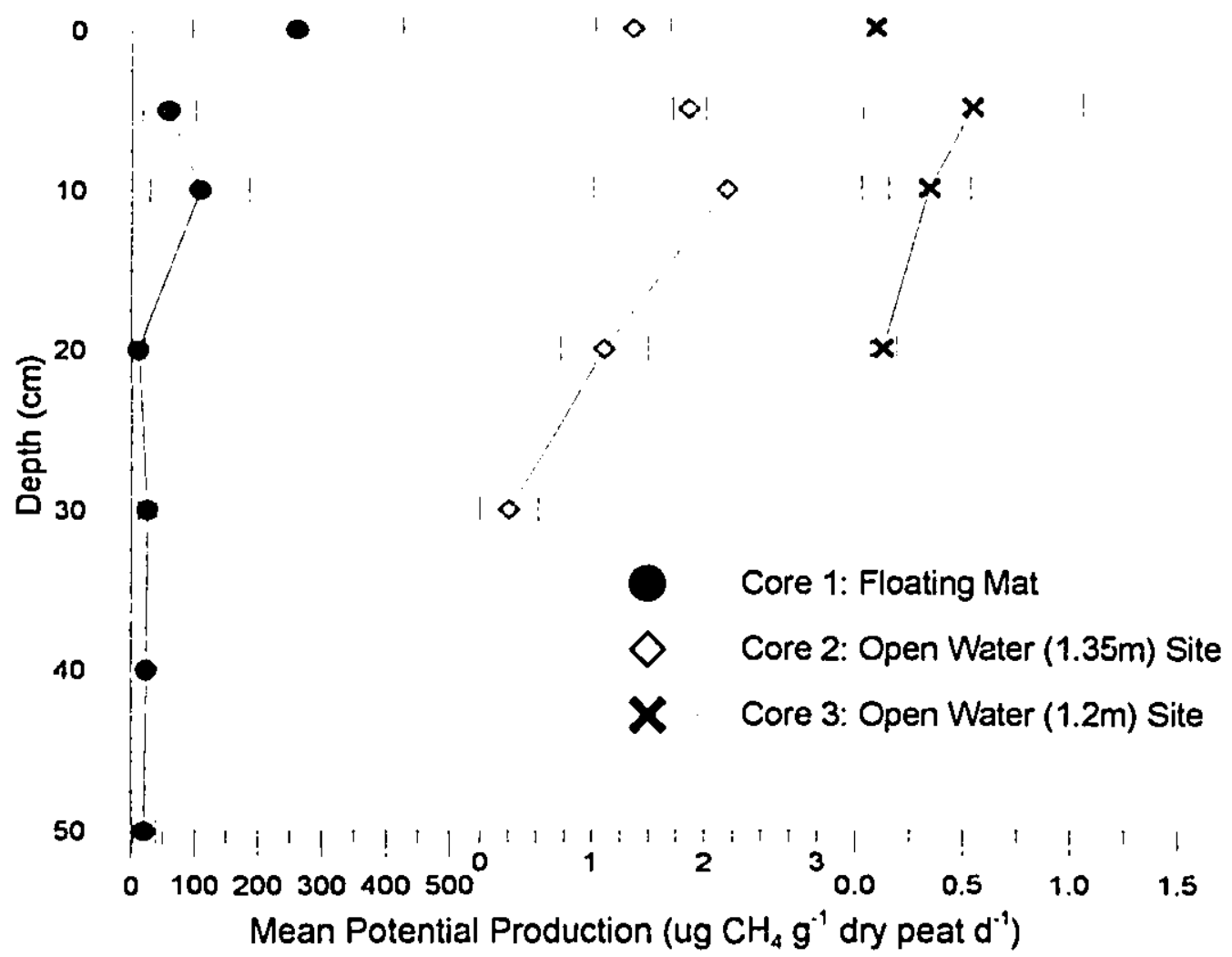

b)

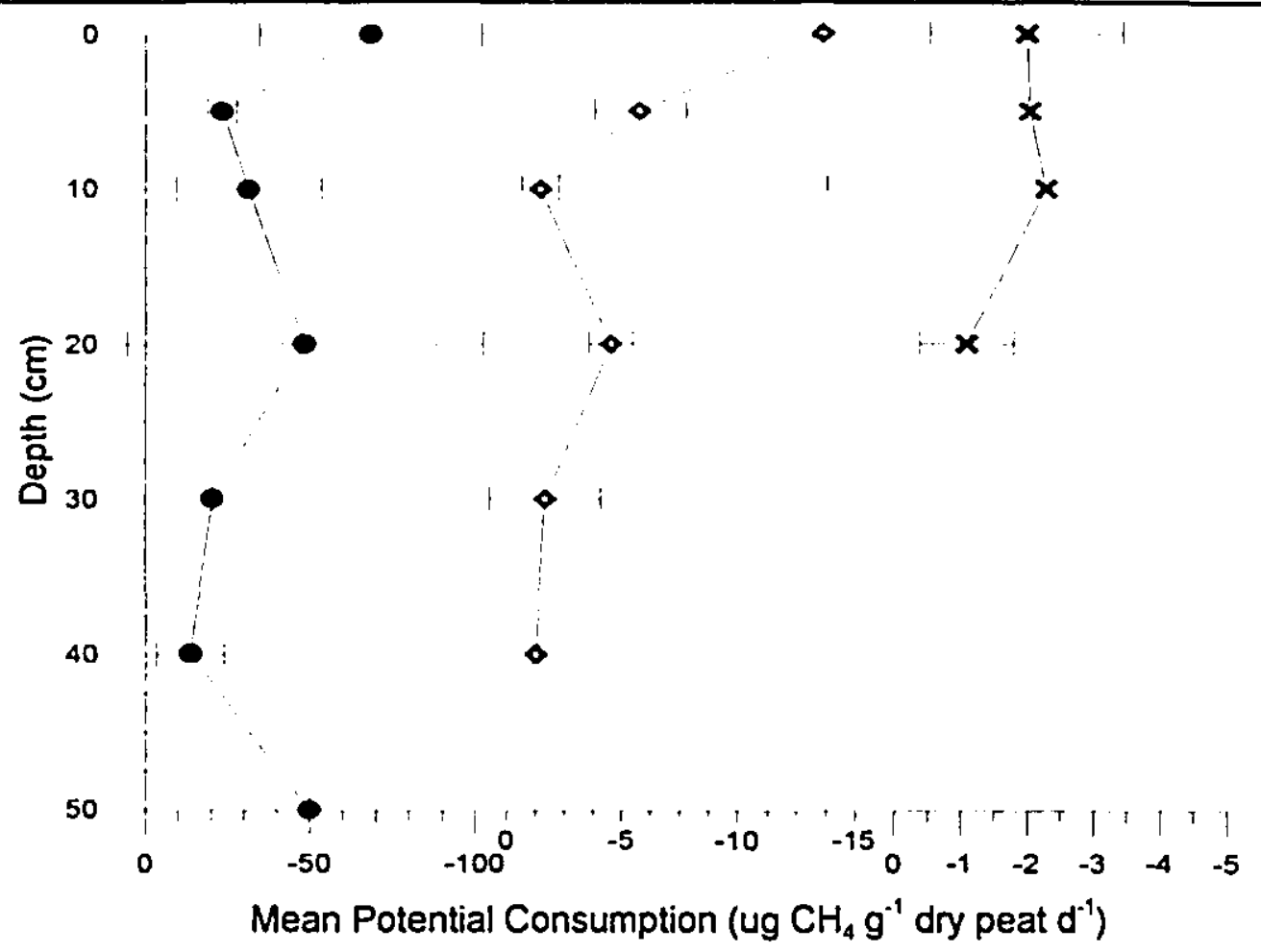

Fig. 3.29 Laborator Incubations of Sediment Samples a) Potential $\mathrm{CH}_{4}$ Production and b) Potential $\mathrm{CH}_{4}$ Consumption, with depth Error bars indicate 1 standard deviation from mean for 3 (production) and 2 (consumption) samples. Legend applies to both graphs. 
Table 3.8 Potential Anacrobic $\mathrm{H}_{4}$ Production and Acrobic $\mathrm{CH}_{4}$ Comsumption of Beaver Pond Sediments Determined in the l aboratory

Values are means of 3 samples (production) and 2 samples (consumption) $\mathrm{SD}=$ standard deviation $\quad \mathrm{CV}=$ coelticient of variation (SD):mean)

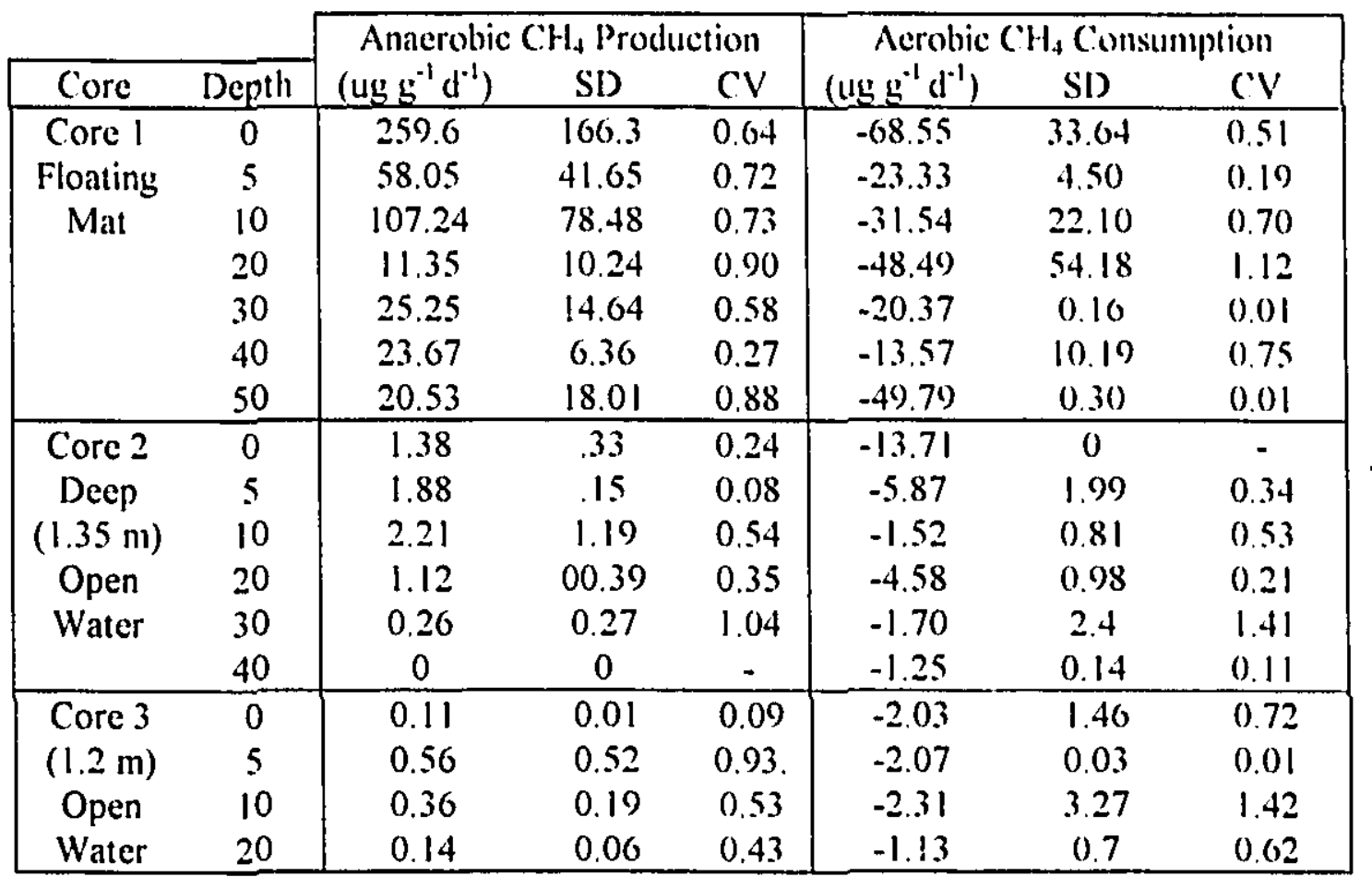

The variability in rates of $\mathrm{CH}_{4}$ production and consumption were both fairly large. Standard deviations of duplicate samples for each depth ranged from 1 to $142 \%$ of the mean for the aerobic $\mathrm{CH}_{4}$ consumption incubations. Standard deviations of $\mathrm{CH}_{4}$ production rates ranged from 9 to $104 \%$ of the mean of triplicate samples at each depth.

Consumption and production potentials were positively related (Fig. 3.30). Layers with low production generally also had low consumption potentials, and those with higher production potentials were greater consumers of $\mathrm{CH}_{4}$. This trend was found in all cores (see inset, Fig. 3.30), although some variation in individual samples 


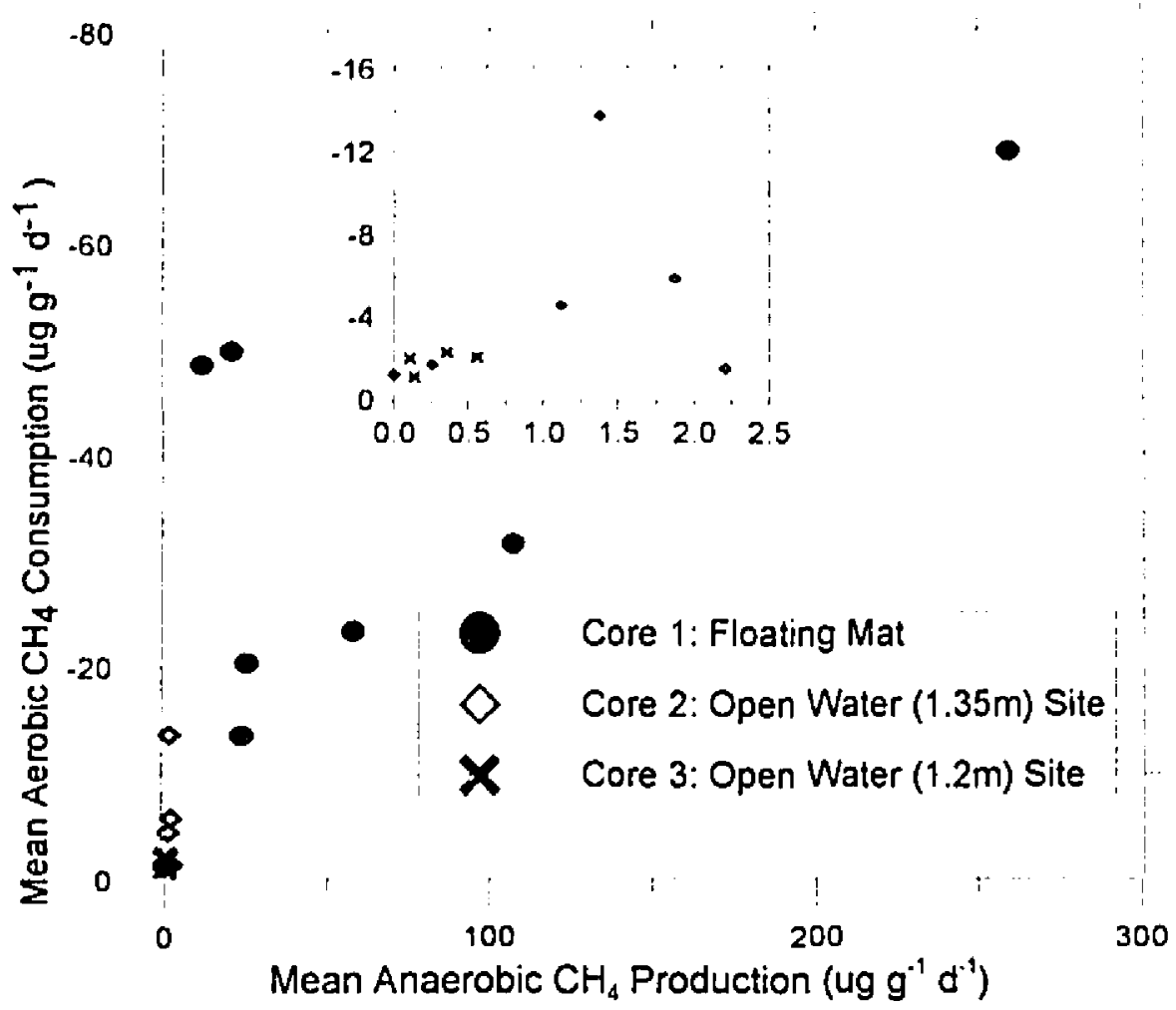

Fig. 3.30 Potential CH Production vs Consu.nption inset graph shows open water sites alone

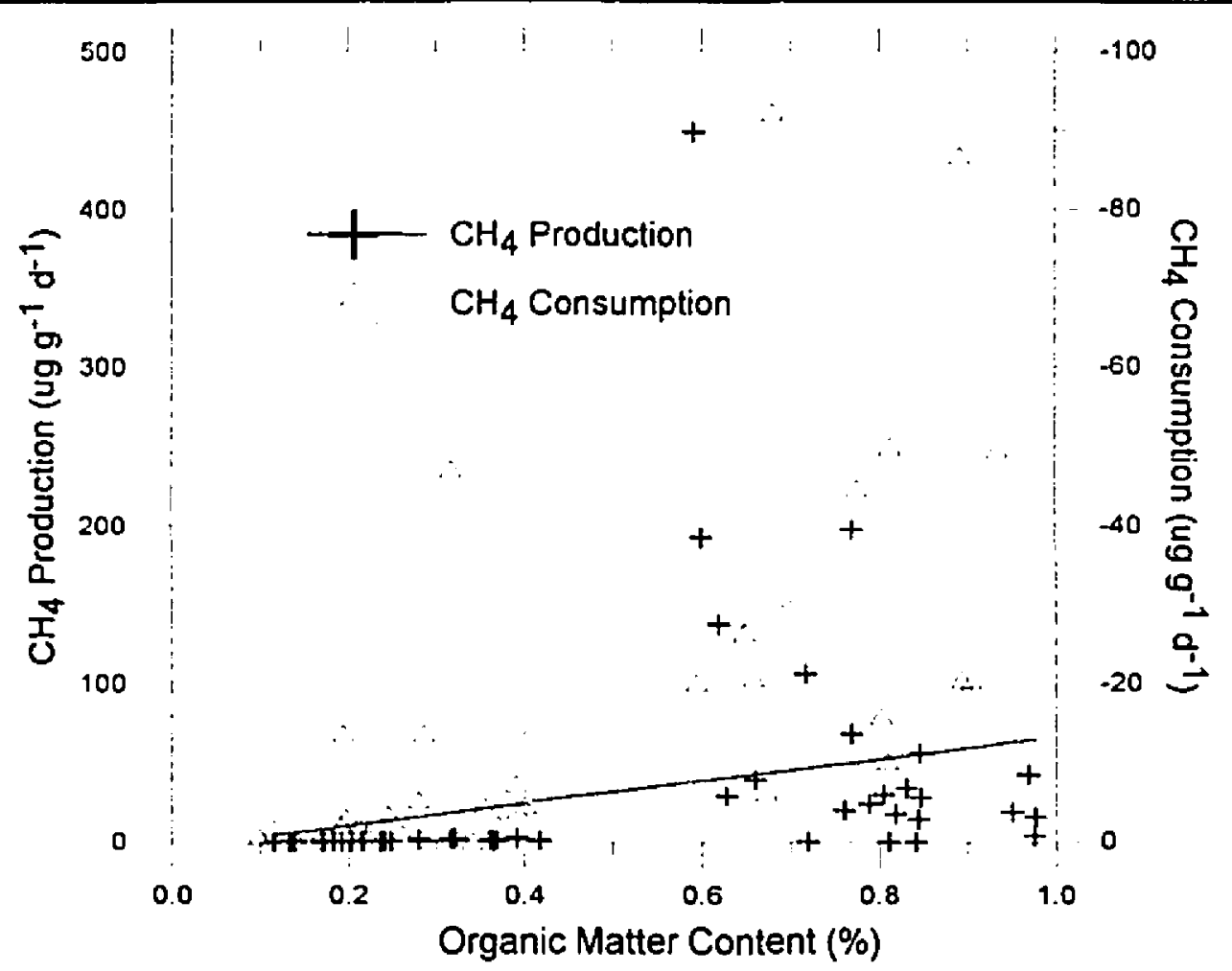

Fig 3.31 Potential_CH Production and Consumption vs. Organic Matter Content 
occurred. In general, open waler sites had low ('Il, production and constumption potentials, and the floating mat site had much higher potentials. I.inear regression of CH. consumption vs production rates yielded the following equation:

Mean potential $\mathrm{CH}_{4}$ production (ug $g^{-1}$ dry peat $\mathrm{d}^{-1}$ ) $\cdots-9.9-2.3 \times$ mean consumption $\mathrm{F}=18.4 \quad \mathrm{r}^{2}=0.55 \quad$ SLE $=4.5 .3 \quad p<0.005 \quad n \cdots 17$

Rates of potential $\mathrm{CH}_{1}$ production and consumption were both positively related to the organic matter content of sediments (Fig. 3.31 ), although the relationship) between production and organic matter was not signilicant.

Potential $\mathrm{CH}_{4}$ consumption (ug $\mathrm{g}^{-1}$ dry peat $\left.\mathrm{d}^{-1}\right)=-8.5-55.5 \times$ organic content $(\%)$ $\mathrm{F}=20.9 \quad \mathrm{r}^{2}=0.40 \quad \mathrm{SEE}=18.7 \quad \mathrm{p}<0.001$ 


\section{Chipler 4: Discussion}

\subsection{InIroduction}

The research objectives and hypotheses out!ined in Section 1.7 were tested during a field campaign from May through September, 199.4. 'The contributions of CII production, consumption and transport to the total the of $\left(1 \mathrm{l}_{1}\right.$ from a beater pond were determined, and the relationships among these processes and envirommental variables were examined.

The following discussion will first examine the total flux of $\left(11_{1}\right.$ from the beaver pond, and compare this flux and its error with the CII, flux reported for other boreal wetlands. The significance of beaver ponds in the regional $\left(1 H_{1}\right.$ budget will be assessed using this comparison and preliminary estimates of the areal coverage of beaver ponds in the region. The relationships between the transport components of the flux (i.e. diffusive, bubble and plant-transported flux) and environmental variables will be examined to determine the probable controls on the transport of $\mathrm{CH}_{4}$. The relative strengths of the production and consumption processes will be deduced. Finally, the controls of these processes will be discussed in light of evidence of differences in $\mathrm{CH}_{4}$ dynamics between vegetated and open water areas of the beaver pond.

\subsection{Total CH, Emissions}

The total flux of $\mathrm{CH}_{4}$ is the sum of the flux transported by bubbling and by diffusion. By adding the mean bubble flux and the mean diffusive flux, the total flux is 
calculated to be $320 \mathrm{mg} \mathrm{CH}_{4} \mathrm{~m}^{-2} \mathrm{~d}^{-1}$ for open water sites and $155 \mathrm{mg} \mathrm{CH}_{4} \mathrm{~m}^{-2} \mathrm{~d}^{-1}$ for vegetated sites in the pond. These lluxes are greater than the flux from other wetland types in the BORI:AS northern study area (Bubier et al, 1995a), except for the flux from an open graminoid fen (Fig. 4.1). The mean fluxes from other wetlands are commonly less than $50 \%$ of the llux from the beaver pond.

Total annual ernissions, calculated by interpolating the mean daily flux data to account for missing sampling dates, and integrating the areas under the curves, are summarized in Fig. 4.2. Cumulative diffusive flux (measured by floating chambers) was similar at open water and vegetated sites, but bubble-transported flux was 5-times greater at open water sites. Therefore, the total flux of $\mathrm{CH}_{4}$ was twice as great at open water sites $\left(30.1 \mathrm{~g} \mathrm{CH}_{4} \mathrm{~m}^{-2} \mathrm{y}^{-1}\right)$ compared to vegetated sites $\left(14.2 \mathrm{~g} \mathrm{CH}_{4} \mathrm{~m}^{-2} \mathrm{y}^{-1}\right)$.

Because differences in flux were observed between open water and vegetated sites, it is important to weight the total flux for the pond according to the relative areas covered by vegetation and open water. Using an aerial photograph (Manitoba Ministry of Natural Resources), the pond was determined to be 5 ha, with vegetation covering $75 \%$ of the pond area and open water comprising the remaining $25 \%$. An areal-weighted flux was determined by summing the products of the annual total emissions by the percent cover for the two classes:

(Open Water Annual Flux $\times \%$ Cover) + (Vegetated Annual Flux $\times \%$ Cover) $=$ Areal-Weighted Annual Flux

$\left(30.1 \mathrm{y} \mathrm{CH}_{4} \mathrm{~m}^{-2} \mathrm{yr}^{-1} \times 0.25\right)+\left(14.2 \mathrm{~g} \mathrm{CH}_{4} \mathrm{~m}^{-2} \mathrm{yr}^{-1} \times 0.75\right)$

$$
=18.2 \mathrm{~g} \mathrm{CH}_{4} \mathrm{~m}^{-2} \mathrm{yr}^{-1}
$$




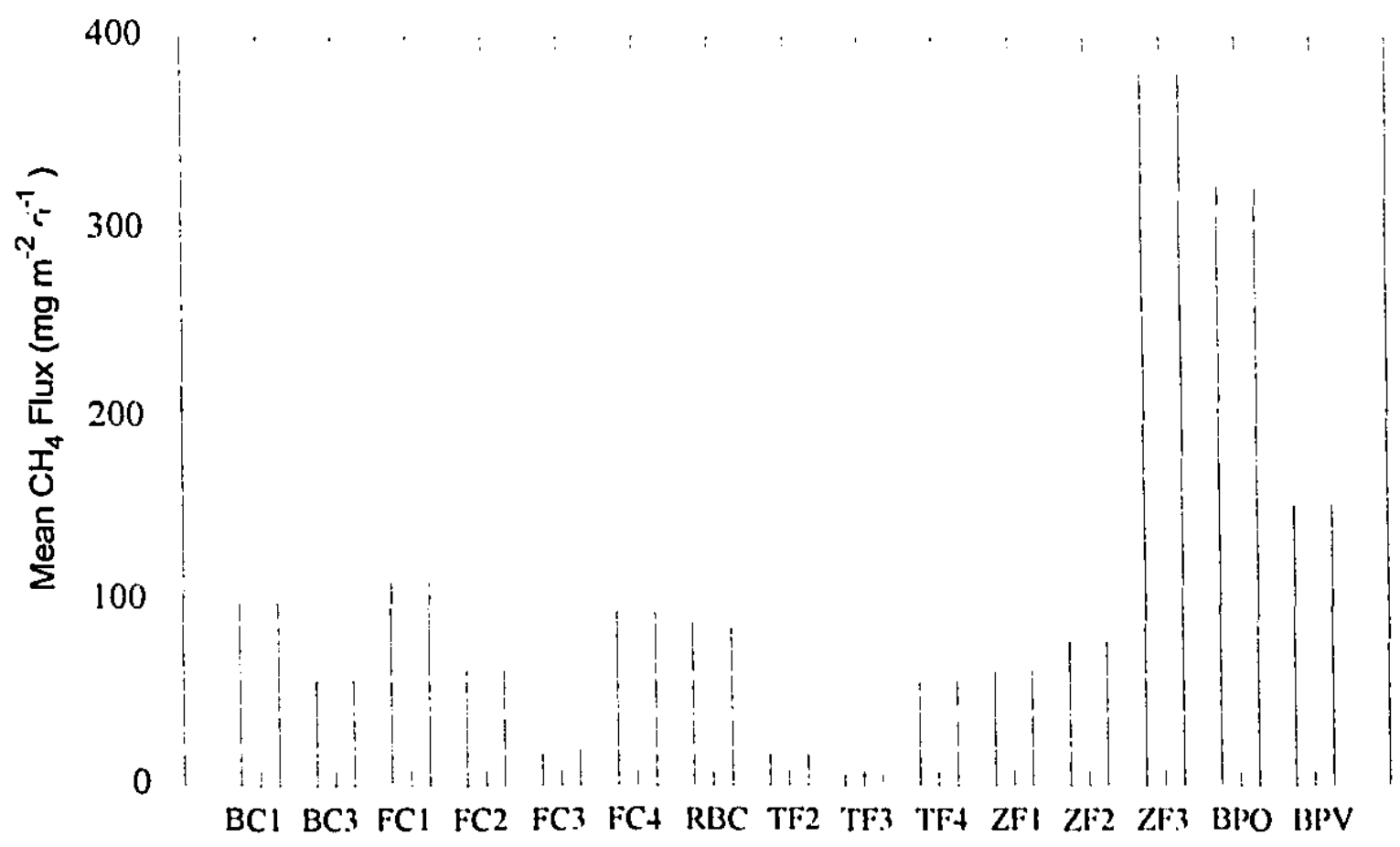

Site

Site Legend:

BC: bog collapse (open low shrub bog);

FC: fen collapse (FC1-2: open graminoid poor fen; FC3: treed low shrub poor fen);

RBC: remote bog collapse (open graminoid bog);

TF: tower fen (TF2: treed lowshrub fen; TF3: treed tallshrub fen; TF4: open lowshrub fen);

ZF: Zoltai fen (ZFI-2: open low shrub fen; ZF3: open graminoid fen);

BP: beaver pond (BPO: open water; BPV: vegetated sites)

All data except beaver pond from Bubier et al., 1995a

Figure 4.1: Comparison of Mean $\mathrm{CH}_{4}$ Fluxes from Wetlands in the BOREAS Northern Study Area, for the period from May 15 to September 15, 1994 
a) Open Water Sites

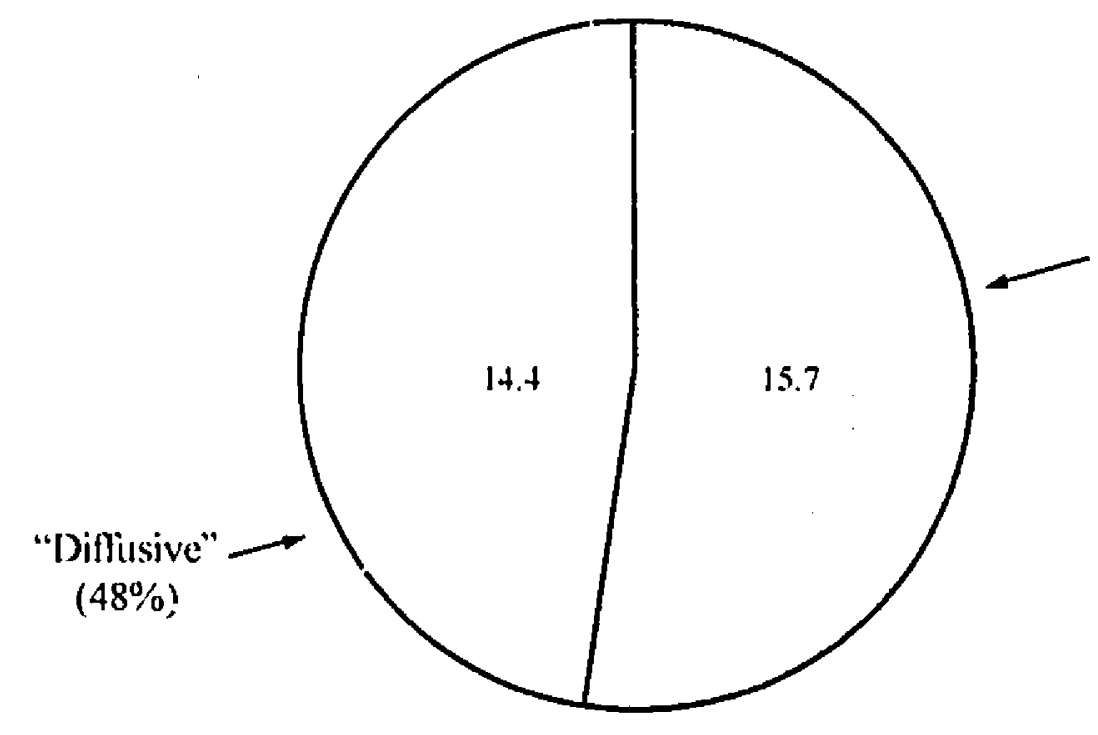

Toral $30 . \lg \left(\mathrm{H}_{\mathrm{s}} \mathrm{m}^{-2} \mathrm{yr}^{-1}\right.$

b) Vegetated Sites

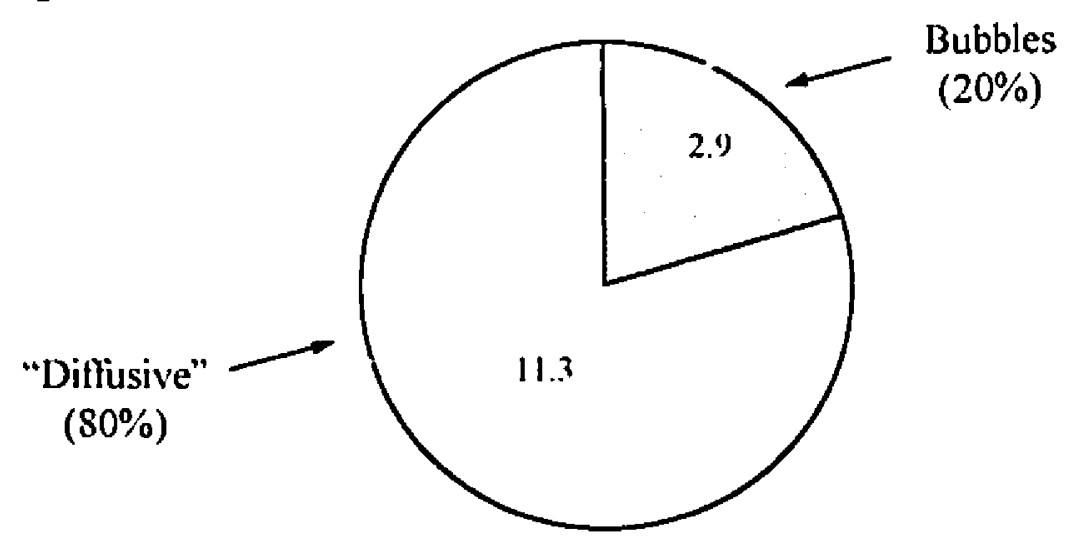

$$
\text { Fotal } \quad 1+.2 g\left(H, m^{-2} y r^{-1}\right.
$$

Fig. 4.2: Total Annual $\mathrm{CH}_{4}$ Emissions from a) Open Water Sites and b) Vegetated Sites, ( $\left.\mathrm{g} \mathrm{CH}_{4} \mathrm{~m}^{-2} \mathrm{yr}^{-1}\right)$ 


\subsubsection{Comparison with Flux Measured from other Beaver Ponds}

Annual $\mathrm{CH}_{4}$ thux from other studies of beaver ponds are presented in thable 4.1.

The flux of $\mathrm{CH}_{4}$ measured here lies within the range measured in these studies.

Table 4.1 Sunmary of CH lilux from Beaver Ponds

\begin{tabular}{|c|c|c|c|c|c|}
\hline Study & Location & Latitude & $\begin{array}{l}\text { Number } \\
\text { of Ponds }\end{array}$ & $\begin{array}{l}\text { Mean Daily } \\
\text { Flux } \\
\left(\text { mug } \mathrm{mi}^{-2} \mathrm{~d}^{-1}\right)\end{array}$ & $\begin{array}{c}\text { Annual } \\
\text { Integrated } \\
\text { l:lux }\left(5 \mathrm{~b}^{-2}\right)\end{array}$ \\
\hline This study & Manitoba & $55^{\circ} 51^{\prime} \mathrm{N}$ & 1 & $\begin{array}{l}154.7^{n} \\
320.7^{11}\end{array}$ & 18.2 \\
\hline Vilt et al., 1990 & Alberta & $54-55^{\circ} \mathrm{N}$ & 1 & 518 & 76.2 \\
\hline $\begin{array}{l}\text { Ford and Naiman, } \\
\qquad 1988\end{array}$ & Quebec & $50^{\circ} 15^{\circ} \mathrm{N}$ & 1 & $\begin{array}{l}2 ! .6 \\
18.7\end{array}$ & 5,9 \\
\hline Bubier et al., 1993 & $\begin{array}{c}\text { northern } \\
\text { Ontario }\end{array}$ & $49^{\circ} \mathrm{N}$ & $\begin{array}{l}1 \\
4 \\
\end{array}$ & $\begin{array}{l}350 \\
290 \\
\end{array}$ & $\begin{array}{l}52.5^{1} \\
43.7^{11}\end{array}$ \\
\hline Naiman et al., !991 & Minnesota & $48^{\circ} 34^{\prime} \mathrm{N}$ & 1 & $\mathrm{n} / \mathrm{a}$ & $\begin{array}{l}14.4^{\circ} \\
11.6^{1}\end{array}$ \\
\hline $\begin{array}{c}\text { Weyhenmeyer, } \\
1992\end{array}$ & Ontario & $45^{\circ} 23^{\prime} \mathrm{N}$ & 1 & 38 & 6.2 \\
\hline Roulet et al., 1992 & Ontario & $45^{\circ} 04^{\prime} \mathrm{N}$ & 3 & $\begin{array}{l}90.6 \\
29.7 \\
47.4 \\
\end{array}$ & 7.6 \\
\hline Windsor, 1993 & $\begin{array}{c}\text { southern } \\
\text { Quebec }\end{array}$ & $45^{\circ} \mathrm{N}$ & 1 & $\begin{array}{l}396 \\
694 \\
\end{array}$ & $\begin{array}{c}78^{4} \\
130^{\mathrm{h}} \\
\end{array}$ \\
\hline Yavitt et al., 1992 & New York & $\begin{array}{l}43^{\circ} 50^{\prime} \mathrm{N} \\
42^{\circ} 52^{\prime} \mathrm{N}\end{array}$ & 2 & $\begin{array}{l}138 \\
162\end{array}$ & $\begin{array}{l}34 \\
40\end{array}$ \\
\hline
\end{tabular}

This study and the study by Weyhenneyer (1992) are the only two in which bubbles were measured explicitly. Chamber methods commonly reject bubbles because the fit of the rise in $\mathrm{CH}_{4}$ concentration over time is poor (e.g. Roulet et al., 1992; Sundh et al., 1995). Bubbles were detected in 5-10\% of the floating chamber measurements in this study, and these data were rejected from the final data set. 
Bubbles, however, were found to be a significant transporter of $\mathrm{Cl}_{4}$ in this beaver pond, comprising $20 \%$ and $52 \%$ of the total flux of $\mathrm{CH}_{4}$ from vegetated and open water sites, respectively. Bubbles have been shown to contribute $65 \%$ of the total flux from a low boreal beaver pond (Weyhenmeyer, 1992) and 50\% of total $\mathrm{CH}_{4}$ emissions from a coastal wetland (Chanton et al., 1989). Using floating chambers alone, therefore, underestimates flux, and future studies of $\mathrm{CH}_{4}$ emissions from flooded wetlands should include separate measurements of bubbles.

The omission of bubble measurement is problematic for open water sites where bubbles comprise more than half of the total $\mathrm{CH}_{4}$ flux. The beaver pond in this study was mostly vegetated, but may not be representative of other boreal beaver ponds in this respect. In a regional survey of 12 beaver ponds in the BOREAS northern study area, most comprised open water only (C. Robinson and N. Roulet, personal communication). Other boreal beaver ponds also comprised open water with smaller amounts of emergent or floating vegetation (e.g Roulet et al., 1992; Weyhenmeyer, 1992). If beaver poids generally contain open water, then any regional extrapolation of measurements without measuring bubbles will seriously underestimate the $\mathrm{CH}_{4}$ flux.

\subsubsection{Regional Significance of $\mathrm{CH}_{4}$ Emissions from Beaver Ponds}

The flux of $\mathrm{CH}_{4}$ from this beaver pond was greater than the flux from most other northern boreal wetland types, but the regional significance of this source depends also on the areal coverage of all ecosystems in the boreal forest and their respective rates of $\mathrm{CH}_{4}$ consumption or emission. The contribution of beaver ponds to 
the $\mathrm{CH}_{4}$ budget of the $1100 \mathrm{~km}^{2}$ BORl:AS northern study area is estimaled assuming the areal coverage of uplands, wetlands, lakes and beaver ponds (Table 4.2). Iilux data from upland and wetland ecosystems were determined in studies by other BOREAS researchers. Two scenarios are presented: scenario I assumes $5 \%$ coverage by beaver ponds, and scenario 2 assumes only $1 \%$ coverage by beaver ponds. Within each scenario, maximum and minimum estimates are derived. The maximum net flux would result from minimum upland $\mathrm{CH}_{4}$ consumption and maximum wetland $\mathrm{CH}_{4}$ enission rates, and the minimum flux assumes maximum upland consumption and minimum wetland flux of $\mathrm{CH}_{4}$.

Table 4.2 $\mathrm{CH}_{4}$ Budget for the BOREAS Northern Study Area

\begin{tabular}{|c|c|c|c|c|c|c|c|c|}
\hline & \multicolumn{2}{|c|}{$\begin{array}{c}\text { Measured } \\
\text { Flux }\left(\mathrm{g} \mathrm{m}^{-2} \mathrm{y}^{-1}\right)\end{array}$} & $\begin{array}{l}\text { Area } \\
(\%)\end{array}$ & \multicolumn{2}{|c|}{$\begin{array}{l}\text { Scenario } 1 \\
\text { Flux }\left(\mathrm{g} \mathrm{m}^{-2} \mathrm{y}^{-1}\right)\end{array}$} & $\begin{array}{l}\text { Area } \\
(\%)\end{array}$ & \multicolumn{2}{|c|}{$\begin{array}{l}\text { Scenario } 2 \\
\text { Flux }\left(\mathrm{g} \mathrm{m}^{-2} \mathrm{y}^{-1}\right)\end{array}$} \\
\hline Uplands $^{1}$ & -0.04 & -0.07 & 50 & -0.02 & -0.035 & 50 & -0.02 & -0.035 \\
\hline Wetlands ${ }^{2}$ & 10 & 8.5 & 25 & 2.5 & 2.125 & 29 & 2.9 & 2.465 \\
\hline Lakes & 0 & 0 & 20 & 0 & 0 & 20 & 0 & 0 \\
\hline $\begin{array}{l}\text { Beaver } \\
\text { Ponds }\end{array}$ & 18.2 & 18.2 & 5 & 0.91 & 0.91 & 1 & 0.182 & 0.182 \\
\hline \multicolumn{3}{|c|}{ Net Flux $\left(\mathrm{g} \mathrm{m}^{-2} \mathrm{y}^{-1}\right)$ : } & & 3.4 & 3.0 & & 3.0 & 2.6 \\
\hline \multicolumn{3}{|c|}{$\begin{array}{l}\text { Contribution of beaver } \\
\text { ponds to net flux: }\end{array}$} & & $27 \%$ & $30 \%$ & & $6 \%$ & $7 \%$ \\
\hline
\end{tabular}

${ }^{1}$ Data from K. Savage, unpubl. data

2 Data from Bubier et al., 1995a

The net flux of $\mathrm{CH}_{4}$ from the NSA is estimated to lie between 2.6 and $3.4 \mathrm{mg}$ $\mathrm{CH}_{4} \mathrm{~m}^{-2} \mathrm{y}^{-1}$ (Table 4.2). The flux from beavet ponds is disproportionately large, and comprises a significant portion of the regional budget. If beaver ponds cover only $1 \%$ 
of the area of the NSA, they may contribute between 6 and $7 \%$ of the total emissions from all wetlands. If beaver ponds cover $5 \%$ of the NSA, they may contribute up to $30 \%$ of all wetland emissions. Any effort to determine the regional flux of $\mathrm{CH}$ from northern boreal areas without consideration of the flux from beaver ponds would underestimate the net flux by up to $30 \%$, and this error would increase if the area of beaver ponds is greater than $5 \%$.

\subsection{Error Analysis}

$\mathrm{CH}_{4}$ emissions from wetlands commonly display high spatial and temporal variability, even within apparently uniform ecological sites (Bubier et al., 1993). Diflerences in emissions may result from this inherent variability, or from actual errors in measurement and/or statistical analysis. While the variance of flux measurements is casily determined, the accuracy of measurements is often impossible to assess.

Fortunately, independent measurements of the $\mathrm{CH}_{4}$ flux from the same beaver pond was made concurrently by other BOREAS researchers.

\subsubsection{Flux Variability}

Emissions of $\mathrm{CH}_{4}$ showed high spatial variability, with standard deviations that often exceeded the daily mean flux. Due to the large sample sizes, however, this observed variability had little effect on the average flux. Variograms (Fig. 4.3) were produced by randomizing the individual flux measurements, and then observing the change in confidence in the mean flux as the sample size was increased. The ratio of 

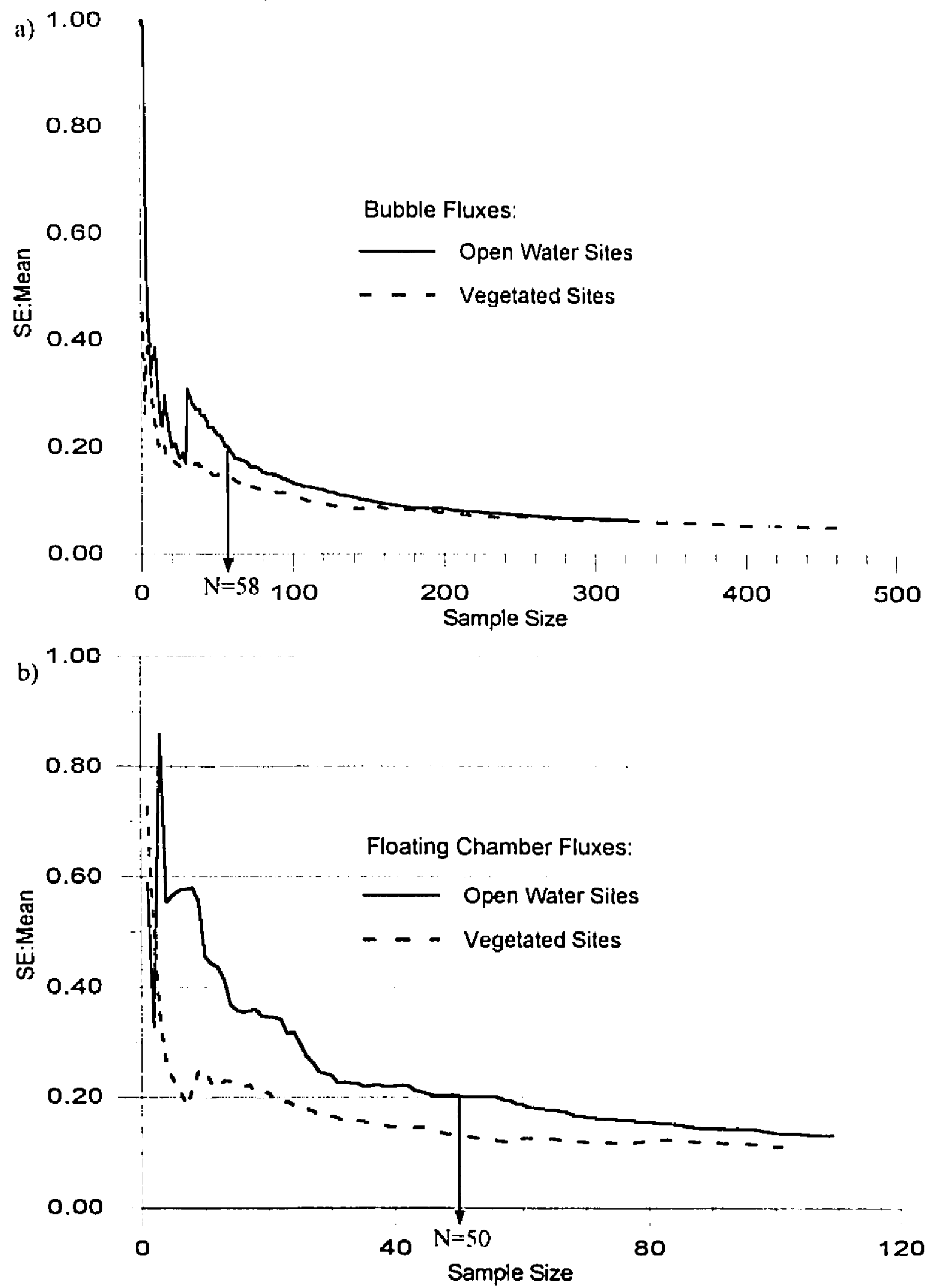

Figure 4.3: Ratio of Standard Error to Mean Flux for differcint sample sizes of randomly selected a) Bubble Flux and b) Floating Chamber Flux data. 
the standard error to the mean flux decreased with increasing sample size, but reasonable confidence in the mean flux (where the standard error is less than $20 \%$ of the mean) was obtained when the floating chamber sample size reached 20 to 50 , and when the bubble flux sample size reached 10 to 60 measurements, depending on the vegetation characteristics of the sites. With additional samples, the means themselves did not change significantly, but the ratio of standard error to mean flux decreased further due to the continued variability in emissions. Since the mean flux changed little after about 60 llux measurements, and the sample sizes obtained in this study were much larger, the accuracy of the flux determined here is considered to be better than \pm $20 \%$.

These results have implications for future measurement programmes. In this study, a large sample size was neccessary because the objectives were to determine the sources and controls of the flux variability. A careful sampling programme, however, using as few as 50 chamber flux and 60 bubble flux measurements over the season, would be sufficient to accurately determine the net flux. Estimating the annual flux by multiplying the measured mean daily flux by the length of the field season would have overestimated the seasonal integrated flux by only $15 \%\left(34.7 \mathrm{~g} \mathrm{CH}_{4} \mathrm{~m}^{-2} \mathrm{yr}^{-1}\right)$ and $22 \%$ $\left(17.4 \mathrm{~g} \mathrm{CH}_{4} \mathrm{~m}^{-2} \mathrm{yr}^{-1}\right)$ for open water and vegetated sites, respectively. Studies to determine the net annual $\mathrm{CH}_{4}$ flux from beaver ponds need to determine the mean flux and length of the emission season. 


\subsection{Flux Accuracy: Comparison with Continuous Tower CH lilux Mensurements}

It is rare that an independent measurement of $\mathrm{CH}_{4}$ thux is available, bu $\mathrm{CH}_{4}$ flux was also measured at the beaver pond using a flux-gradient approach from a $1.5 \mathrm{~m}$ micrometeorological tower with a 50-120 m footprint over the pond (P. Crill and $\mathrm{N}$. Roulet, unpubl. data). Mean daily flux measured from the tower ranged from 29 to $282 \mathrm{mg} \mathrm{CH}_{4} \mathrm{~m}^{-2} \mathrm{~d}^{-1}$, which agrees well with the areal-weighted flux calculated in this study (193 $\left.\mathrm{mg} \mathrm{CH}_{4} \mathrm{~m}^{-2} \mathrm{~d}^{-1}\right)$. The annual flux from the tower $\left(11.1 \mathrm{~g} \mathrm{CH}_{4} \mathrm{~m}^{-2} \mathrm{yr}^{-4}\right.$, calculated by interpolating and integrating daily mean flux over the season) was lower than that measured here using static chambers and funnels $\left(18.2 \mathrm{~g} \mathrm{CH}_{4} \mathrm{~m}^{-2} \mathrm{yr}^{-1}\right)$, but the tower may not measure bubble emissions accurately. High concentrations of $\mathrm{Cl}_{4}$ in the air above the pond (presumably resulting from bubble emissions) were often observed in the tower data, but some of these were only observed at the higher sampling inlet. Since the tower flux calculations rely on the gradient of atmospheric $\mathrm{CH}_{4}$, a downward gradient of $\mathrm{CH}_{4}$ thus measured results in a calculated uptake rather than efflux, and leads to an underestimate of net emissions from the pond.

In general the $\mathrm{CH}_{4}$ flux measured from the tower is lower than the net (floating chamber + bubble) flux measured in this study (Fig. 4.4a), but it is similar to the floating chamber flux alone (Fig. 4.4b). Indeed, the annual areal-weighted tlux from floating chambers (12.1 $\left.\mathrm{g} \mathrm{CH}_{4} \mathrm{~m}^{-2} \mathrm{yr}^{-1}\right)$ compares well with the tower flux (11.1 $\mathrm{g} \mathrm{CH}_{4}$ $\mathrm{m}^{-2} \mathrm{yr}^{-1}$ ). Statistical comparisons (Mann-Whitney $U$ tests) indicated that the mean daily flux measured at the tower was greater than the floating chamber flux $(U=1174$, 


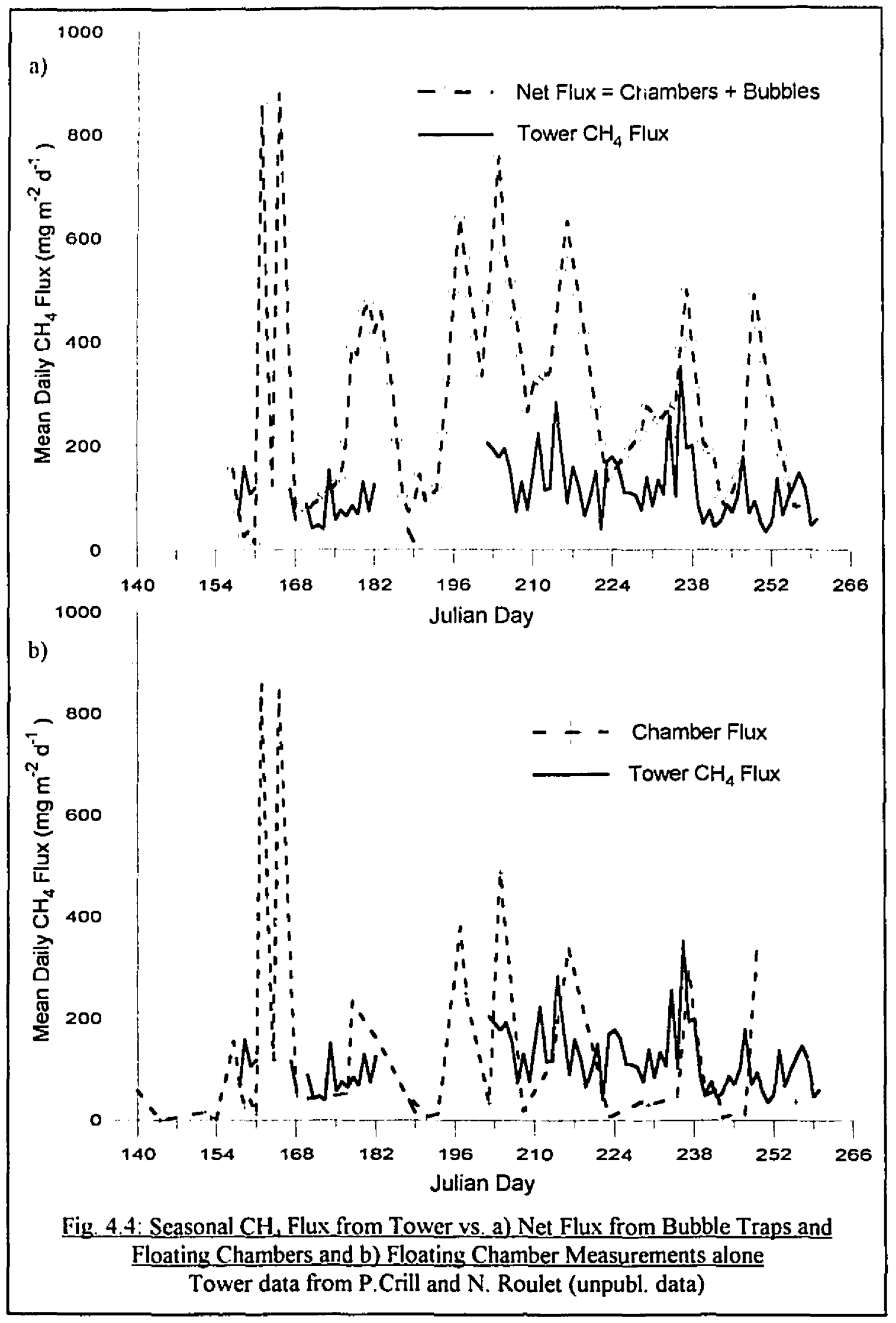


p<0.01) (Fig 4.5a), but less than the bubble llux (U - 16.39, p.0.05) (lig + $4.5 b)$ measured at open water sites. The flux measured from the tower, therefore, lies between the flux from diffission and bubbles (Table 4.3). Since the fower may not accurately measure bubble enissions, the flux-gradient results independently contirm that the results presented here are a reasonable estimate of spatially-averaged $\mathrm{CH}_{\mathrm{.}}$ emissions from the beaver pond.

Table 4.3 Comparison of $\mathrm{CH}_{4}$ Flux Measured Continuously at the Tower with Chamber and Bubble Flux Measurements

\begin{tabular}{|c|c|c|c|c|c|}
\hline Statistic & $\begin{array}{l}\text { Open Water } \\
\text { Chamber Flux }\end{array}$ & $\begin{array}{c}\text { ('arcx Site } \\
\text { Chamber Flux }\end{array}$ & Tower Flux & $\begin{array}{l}\text { Open Water } \\
\text { Bubble Flux }\end{array}$ & $\begin{array}{l}\text { Vegetated Site } \\
\text { Bubble Flux }\end{array}$ \\
\hline$N$ (days) & 41 & 37 & 82 & 51 & 51 \\
\hline Min. & 1.2 & 0.7 & 15.3 & 0.02 & 0.01 \\
\hline Max. & 856.4 & 476.9 & 351.6 & 443.2 & 89.54 \\
\hline Mean & 141.4 & 109.1 & 112.5 & 156.7 & 20.0 \\
\hline $\mathrm{SD}$ & 208.4 & 97.8 & 60.6 & 112.6 & 21.6 \\
\hline Median & 47.9 & 89.8 & 103.8 & 172.4 & 22.2 \\
\hline
\end{tabular}

\subsubsection{Arithmetic vs. Geometric Means}

Other investigators have criticized the use of arithmetic means in $\mathrm{CH}_{4}$ flux studies (e.g. Wehenmeyer, 1992). Geometric means may be more appropriate than arithmetic means when distributions are positively skewed because high values tend to inflate arithmetic means. Arithmetic means were used here, however, despite the skewed distribution of flux measurements, because several fluxes were zero or negative which caused geometric means to be indefinite. Geometric means were calculated where possible, and cumulative emissions were compared using the two 
a)

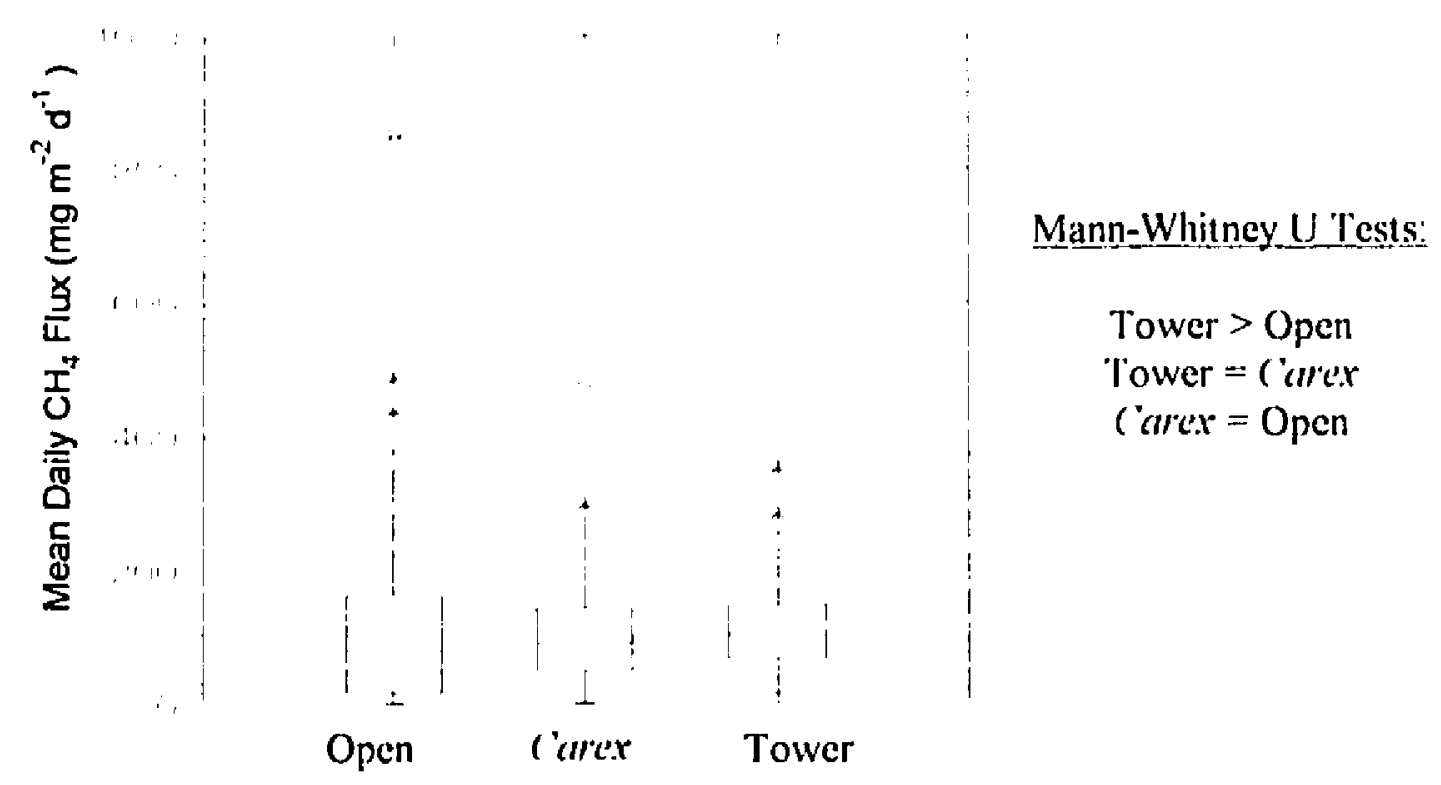

b)

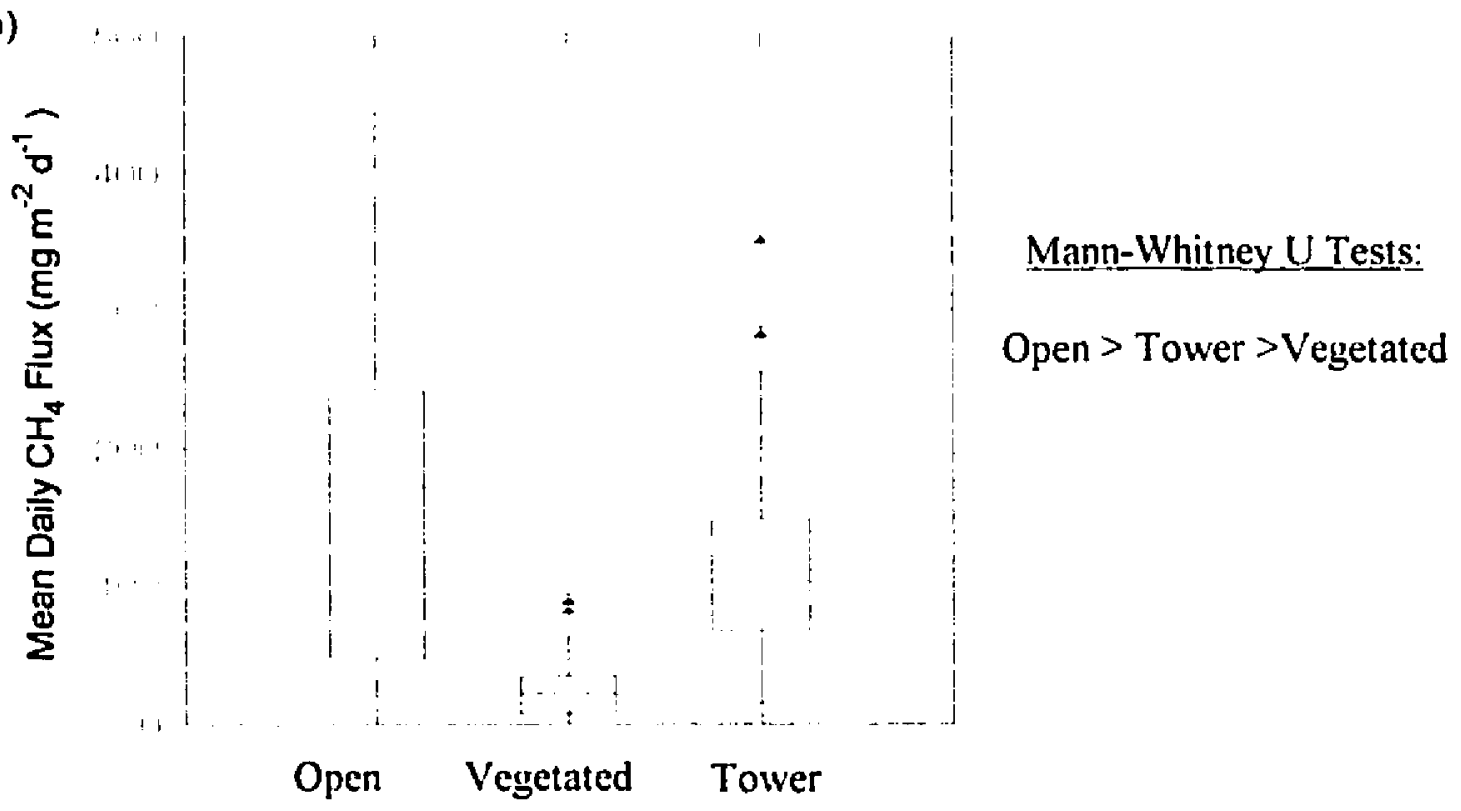

Fig. 4.5 Comparison of Mean Daily $\mathrm{CH}_{4}$ Flux Measured from the Tower vs a) Floating Chamber Measurements and

b) Bubble Flux Measurements from this study

Tower data from P.Crill and N. Roulet (unpubl. data) 
methods (Table 4.4). Annual emissions calculated by inegrating geometric mean daily fluxes were roughly 10 to $20 \%$ lower than those calculated using arithmetic means, but the contributions of bubbles and floating chamber fluxes to the total flux remained very similar. Correlation coefficients between geometric mean daily flux and environmental factors did not differ significantly from those reported for arithmetic means (Sections 3.2.3 and 3.3.3). Furthermore, the variograms presented above and the agreement with the tower flux measurements indicate that the arithmetic mean provides a reliable estimate of flux.

Table 4.4 Comparison of Annual $\mathrm{CH}_{4}$ Flux Calculated by Integrating Geometric and Arithmetic Mean Daily Flux

\begin{tabular}{|c|c|c|c|c|c|c|}
\cline { 2 - 7 } \multicolumn{1}{c|}{} & \multicolumn{2}{c|}{$\begin{array}{c}\text { Chamber Flux } \\
\left(\mathrm{g} \mathrm{m}^{-2} \mathrm{yr}^{-1}\right)\end{array}$} & \multicolumn{2}{c|}{$\begin{array}{c}\text { Bubble Flux } \\
\left(\mathrm{g} \mathrm{m}^{-2} \mathrm{yr}^{-1}\right)\end{array}$} & \multicolumn{2}{c|}{$\begin{array}{c}\text { Total Flux } \\
\left(\mathrm{g} \mathrm{m}^{-2} \mathrm{yr}^{-1}\right)\end{array}$} \\
\hline & Vegetated & Open & Vegetated & Open & Vegetated & Openl \\
\hline Aritlumetic Mean & 11.3 & 14.4 & 2.9 & 15.7 & 14.2 & 30.1 \\
\hline Gcometric Mean & 10.3 & 12.2 & 2.4 & 12.5 & 12.7 & 24.7 \\
\hline \% Difference' & -9 & -15 & -18 & -21 & -11 & -18 \\
\hline
\end{tabular}

1 (integrated daily arithmetic mean flux - integrated daily geometric mean flux) $\times 100$ integrated daily arithmetic mean flux

\subsubsection{Possible Errors in Floating Chamber Measurements}

As described in the results (Section 3.2.1), the density of (arex at the selected sites along the boardwalk may have been too low to detect enhancement of flux by these plants. (arex densities were generally only I to 3 plants within a chamber, and the annual flux resembled that from unvegetated sites. Enhanced flux through ('arex has been found in other studies (e.g. Whiting and Chanton, 1992; Bubier et al., 
1995a), and is suspected here because higher fluxes were observed in the tower $\mathrm{CH}_{4}$ flux data ( $P$. Crill and N. Roulet, unpubl, data) when the wind was blowing from densely vegetated areas of the pond (Fig. 4.6). Furthermore, the tower data showed marked diel variation (Fig, 4.7), with daytime enhancement of flux concurrent with photosynthetic activity. Therefore, the reported annual flux from ('arex sites (11.3 g $\left.\mathrm{CH}_{4} \mathrm{~m}^{-2} \mathrm{y}^{-1}\right)$ and the areal-weighted flux $\left(18.2 \mathrm{~g} \mathrm{CH}_{4} \mathrm{~m}^{-2} \mathrm{y}^{-1}\right)$ are likely underestimates. Since most beaver ponds in the region appear to be largely unvegetated, this error is not considered to affect the regional assessment of the importance of $\mathrm{CH}_{4}$ emisisons from beaver ponds. At worst, the regional budget may underestimate the role of beaver ponds since the areal-weighted flux for beaver ponds used in the budget may be too low.

Rates of bubbling and $\mathrm{CH}_{4}$ concentrations in bubbles were high, yielding high bubble fluxes from this pond. It is possible that small bubbles contributed to flux measurements made with floating chambers (cf. Yavitt et al., 1990). Large bubbles that entered floating chambers were easily detected in the time series of $\mathrm{CH}_{4}$ measurements (they were detected in 5-10\% of all floating chamber fluxes), but smaller bubbles may have entered chambers at a linear rate since chamber fluxes were negatively (but poorly) correlated with atmospheric pressure ( $r \geq-0.26$; Section 3.3.3). The only way in which atmospheric pressure should correlate negatively with floating chamber measurements is if bubble release is related to atmospheric pressure (or some other co-dependent variable) and if bubbles were measured in chambers. If small bubbles contributed to floating chamber flux measurements, then the total flux 



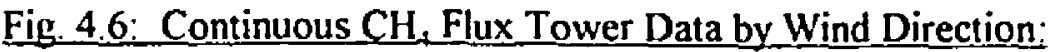
a) Flux and b) \% Contribution to Total Flux (P. Crill and N. Roulet, unpubl. data) 


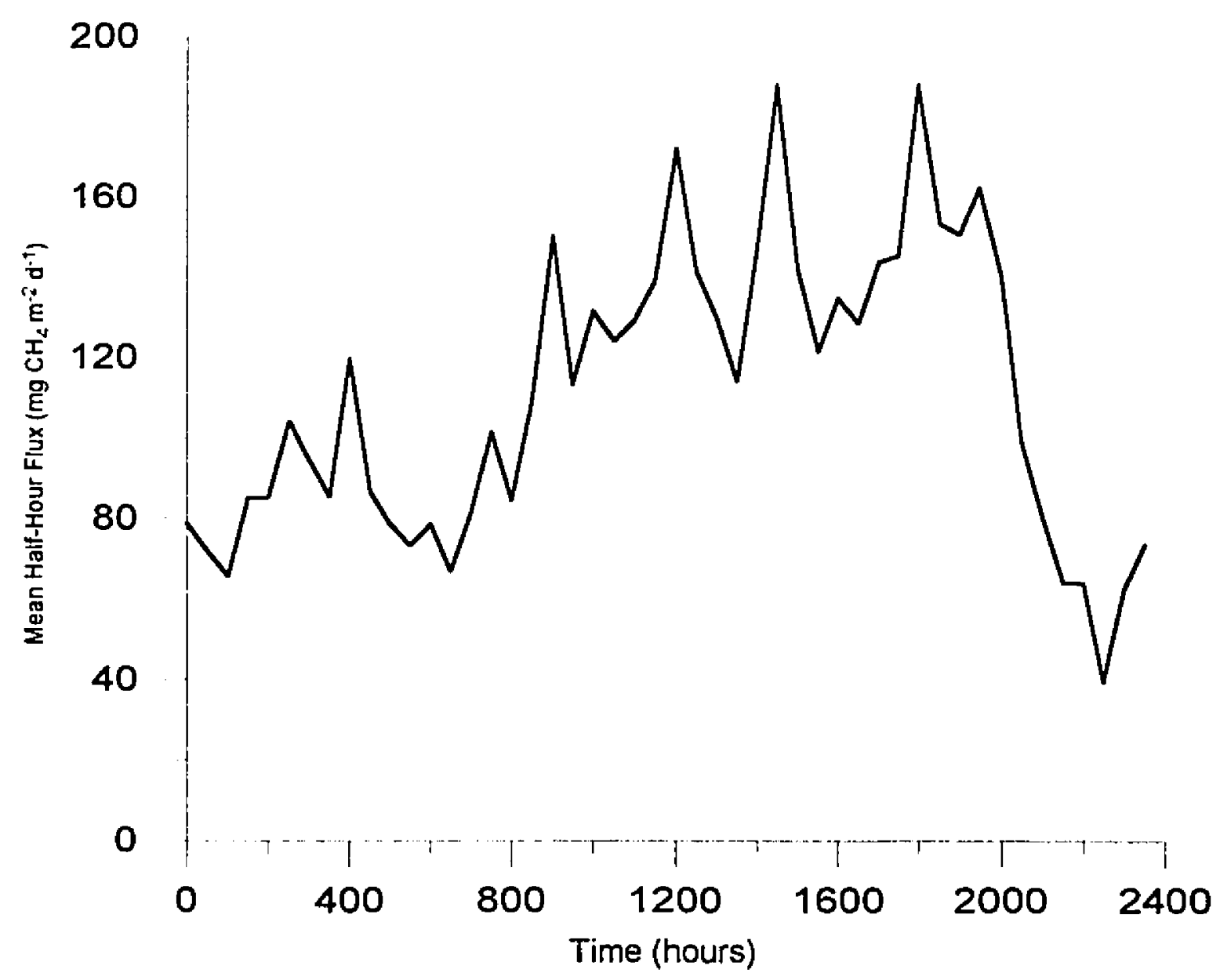

Fig. 4.7: Diel Variation in Continuous Tower $\mathrm{CH}_{4}$ Flux Data (P. Crill and N. Roulet, unpubl. data) 
calculated by sumning floating chamber and bubble fluxes will be overestimated since small bubbles are included in both measurements. Uniortunately, there is no way to identify whether this is the case, although it is unlikely since atmospheric pressure was not a significant predictor of floating chamber flux using multiple regression analysis (Section 3.2.3).

\subsubsection{Winter $\mathrm{CH}_{4}$ Emissions}

Studies of $\mathrm{CH}_{4}$ emissions from wetlands have traditionally assumed that winter fluxes are negligible due to low temperatures and cover by snow and ice. A few studies have recently included measurements over a full annual cycle (Whalen and Reeburgh, 1992; Dise et al., 1993). No measurements of winter $\mathrm{CH}_{4}$ emissions were made here, but seasonal changes in the $\mathrm{CH}_{4}$ pool size indicate that $\mathrm{CH}_{4}$ stored in sediments in the fall is either released and/or oxidized before spring. In the spring, a small sediment $\mathrm{CH}_{4}$ pool was present, but when sampling was terminated, a large $\mathrm{CH}_{4}$ pool remained. Assuming no $\mathrm{CH}_{4}$ is oxidized but $\mathrm{CH}_{4}$ production ceases, winter $\mathrm{CH}_{4}$ emissions can be calculated as the difference between fall and spring storage (Table 4.5).

Table 4.5 Winter $\mathrm{CH}_{4}$ Emissions Calculated as the Difference between Fall and Spring Porewater $\mathrm{CH}_{4}$ Storage

\begin{tabular}{|l|c|c|}
\cline { 2 - 3 } \multicolumn{1}{c|}{} & Open Water Sites $\left(\mathrm{g} \mathrm{m}^{-2}\right)$ & Vegetated Sites $\left(\mathrm{g} \mathrm{m}^{-2}\right)$ \\
\hline Fall Porewater $\mathrm{CH}_{4}$ Storage & 8.0 & 10.8 \\
\hline Spring Porewater Storage & 1.6 & 0.9 \\
\hline Winter Flux (Difference) & 6.4 & 9.9 \\
\hline Total Annual Flux & 36.5 & 24.1 \\
\hline
\end{tabular}


Including winter emissions results in new estimates of annual flux. Estimated winter emissions comprise only $18 \%$ of total annual flux from open water sites, but comprise $41 \%$ of the flux from vegetated sites. Since low rates of $\mathrm{CH}_{4}$ production, and particularly $\mathrm{CH}_{4}$ oxidation, may continue over the winter, these figures provide only a rough estimate of the winter flux of $\mathrm{CH}_{4}$ from the pond.

Weyhenmeyer (1992) estimated that winter net production comprised $23 \%$ of the annual $\mathrm{CH}_{4}$ flux from a low boreal beaver pond, based on an increase in the concentration of $\mathrm{CH}_{4}$ in surface waters below ice between November and February, and assuming that production rates were constant and that $\mathrm{CH}_{4}$ oxidation and release were negligible. No other information about winter emissions from beaver ponds is available, but the available evidence indicates that the winter flux may be significant.

\subsection{Environmental Controls of $\mathrm{CH}_{4}$ Emissions}

The flux of $\mathrm{CH}_{4}$ from a bei:ier pond results from production, consumption and transport processes. It is the contention here that the primary controls on $\mathrm{CH}_{4}$ flux are those that affect the availability of $\mathrm{CH}_{4}$ (i.e.production and oxidation), and the secondary controls are those that affect the transport of $\mathrm{CH}_{4}$ from the sediments to the atmosphere. Primary factors such as temperature will control rates of production and oxidation, and will therefore control the amount of $\mathrm{CH}_{4}$ that is available for release. The amount of $\mathrm{CH}_{4}$ available and the amount actually emitted are not equal, however, due to storage of $\mathrm{CH}_{4}$ in the sediments and differential rates of oxidation as $\mathrm{CH}_{4}$ is transported by different pathways (diffusion, bubbles, and plant-mediated transport). 


\subsubsection{Primary Controls on $\mathrm{CH}_{4}$ Availability.}

The amount of $\mathrm{CH}_{4}$ available for release depends on the rates of $\mathrm{CH}_{4}$ production and oxidation, and also on the size of the storage reservoir in the sediments. Since temperature directly controls rates of $\mathrm{CH}_{4}$ production and oxidation, flux patterns broadly followed trends in sediment temperature, with other factors influencing emissions at specific times. At the beginning of the field season, temperature, porewater $\mathrm{CH}_{4}$ concentrations, and lluxes were all low, therefore production of $\mathrm{CH}_{4}$ was probably low. As sediment temperature increased, the flux measured in floating chambers and porewater $\mathrm{CH}_{4}$ concentrations increased. Sediment temperature continued to increase after porewater concentrations reached saturation, and rates of production exceeded the capacity for diffusive loss of $\mathrm{CH}_{4}$; therefore, significant ebullition occurred (cf. Chanton and Dacey, 1991). By the end of the sampling programme, near-surface sediment temperature was decreasing and production may have declined because both flux and storage were declining.

$\mathrm{CH}_{4}$ producers (methanogens) and $\mathrm{CH}_{4}$ consumers (methanotrophs) respond differently to temperature (Dunfield et al., 1993). Diffusing $\mathrm{CH}_{4}$ is subject to oxidation during transport, and emissions will be the result of both production and oxidation processes. The relationship between diffusive $\mathrm{CH}_{4}$ flux and sediment temperature will therefore be complicated because two groups of organisms are involved. Bubble flux should be more directly related to the production of $\mathrm{CH}_{4}$ because the potential for oxidation is greatly reduced during bubble transport. Indeed, 
sediment temperature was a stronger predictor of bubble flux $\left(r^{2}=0.45\right.$ to 0.64$)$ than the flux measured in floating chambers $\left(r^{2}=0\right.$ to 0.11$)$ (Sections 3.2.3 and 3.3.3).

The relationship between sediment temperature and floating chamber flux was strongest when temperature was increasing monotonically rather than decreasing. This may also be due to the different temperature responses of $\mathrm{CH}_{4}$ producers and consumers.

Photosynthetically active radiation may enhance $\mathrm{CH}_{4}$ flux as indicated by the positive relationship between PAR and sediment temperature. Smoke from forest fires reduced PAR between J.d. 182 and 187 , causing a decline in sediment temperature and there was a corresponding decline in $\mathrm{CH}_{4}$ flux. Plant transport of $\mathrm{CH}_{4}$ may also be enhanced by PAR. Increasing PAR may attenuate flux, however, because higher rates of photosynthesis by aquatic plants and epiphytic algae increase the amount of oxygen available for use by $\mathrm{CH}_{4}$-consumers in the sediments (King, 1990). A significant but weak negative relationship was found between PAR and open water chamber fluxes (Section 3.2.3). This might be due to enhancement of $\mathrm{CH}_{4}$ oxidation fueled by $\mathrm{O}_{2}$ production at the sediment-water interface.

Other factors besides temperature will affect the availability of $\mathrm{CH}_{4}$ for emission from a beaver pond. Substrate characteristics such as $\mathrm{pH}$, nutrients, and organic matter content and quality likely affect rates of $\mathrm{CH}_{4}$ production and oxidation, but these characteristics were not tested in the field. There were positive relationships between both $\mathrm{CH}_{4}$ production and consumption rates and organic matter content when measured in the laboratory, but these relationships were generally weak. Production 
and consumption were also strongly correlated with each other $(r=-0.84$; where consumption rates are negative). Therefore, sites with higher organic matter contents tend to both produce and consume more $\mathrm{CH}_{4}$ because high organic content enhances methanogenesis, and populations of methanotrophs are greatest where $\mathrm{Cl}_{4}$ is abundantly available (Svensson and Sundh, 1992; Sundh et al., 1995).

The degree of anaerobism also affects the balance between $\mathrm{CH}_{4}$ production and oxidation. In other types of wetlands, where the water table is below the wetland surface, a large aerobic zone is present, and oxidation can significantly reduce the $\mathrm{CH}_{4}$ flux (e.g. Fechner and Hemond, 1992; Moore et al., 1994). Since the sediments in beaver ponds are continuously saturated, anaerobic conditions dominate, and oxidation is minimized compared to other wetlands. The strongest predictors of $\mathrm{CH}_{4}$ llux from other wetlands are the position of the water table and temperature. In beaver ponds, small changes in pond level do not affect anaerobism. Sediment temperature is therefore the dominant factor controlling $\mathrm{CH}_{4}$ availability.

\subsubsection{Secondary Controls on $\mathrm{CH}_{4}$ Release: Diffusion}

The rate of $\mathrm{CH}_{4}$ diffusion depends on the concentration gradient of $\mathrm{CH}_{4}$, and the conductance (or resistance) of the system to its transport. Virtually all of the resistance to the water-air transfer of $\mathrm{CH}_{4}$ has be shown to occur in the liquid phase (Denmead and Freney, 1992). Therefore, the rate-limiting step for release of $\mathrm{CH}_{4}$ from aquatic systems is the supply of $\mathrm{CH}_{4}$ to surface waters. Turbulent mixing of the water column effectively transports $\mathrm{CH}_{4}$-rich water from deeper layers at rates greater 
than diffusion alone could achieve. Because convective mixing of water is a function of windshear, windspeed controls the transport of $\mathrm{CH}_{4}$ to the surface. Mean daily windspeed was the strongest predictor of $\mathrm{CH}_{4}$ flux measured in floating chambers, explaining up to $35 \%$ of the variance in flux (Section 3.2.3). Although atmospheric mixing by winds is eliminated within the floating chambers, in the water under the enclosure considerable wind-induced mixing continues due to momentum in the water column. If the rate-limiting step for diffusion of $\mathrm{CH}_{4}$ is on the atmospheric side of the water-air interface, then no relationship between windspeed and flux would be expected because windspeed inside the floating chambers is zero. Clearly, the transport of $\mathrm{CH}_{4}$ from deeper layers to the surface controls the flux across the waterair interface.

One would expect higher fluxes from shallow sites because wind-induced mixing penetrates water layers with higher $\mathrm{CH}_{4}$ concentrations at these sites. Flux may also decrease as the depth of water increases if diffusing $\mathrm{CH}_{4}$ is oxidized in the water column (Rudd and Taylor, 1980). However, water depth was not a significant predictor of chamber fluxes here. Most sites sampled by chambers (85\%) were deeper than $0.4 \mathrm{~m}$. Since profiles of $\mathrm{CH}_{4}$ concentrations in the upper $40 \mathrm{~cm}$ of the water column were similar between sites (see Fig. 3.25), intersite depth differences should not explain flux variability. Additionally, as explained below, open water oxidation is likely negligible in this pond. 


\subsubsection{Secondary Controls on $\mathrm{CH}_{4}$ Relense:_Bubbles}

Rates of $\mathrm{CH}_{4}$ production exceded rates of removal by diflusion and oxidation since porewaters became supersaturated with respect to $\mathrm{CH}_{4}$. Bubbles, consisting of $\mathrm{CH}_{4}$ and other gases (presumably $\mathrm{N}_{2}$, Ar and small amounts of $\mathrm{O}_{2}$ : Chanton et al., 1989) were formed in the sediments. Assuming that these bubbles maintain equilibrium with hydrostatic pressure, changes in pressure may cause some bubbles to be released (Mattson and Likens, 1990). If the overlying pressure, which is exerted by the atmosphere and the water column, decreases below the internal bubble pressure, bubbles will be released into the water column, where they will rise to the surface and burst upon contact with the atmosphere.

Atmospheric pressure controlled bubble flux once the primary control of sediment temperature on production was considered. Atmospheric pressure was a weak predictor of bubble flux overall, explaining only $4 \%$ and $11 \%$ of variance in open water and vegetated site mean daily flux, respectively. However, during the middle of the season (J.d. 182-216) when sediment temperature was highest and least variable, atmospheric pressure explained $26 \%(p<0.05)$ and $61 \%(p<0.001)$ of the variance in open water and vegetated site mean daily bubble flux, respectively.

Other investigators have found that pressure changes influence bubbling in inundated wetlands. Weyhenmeyer (1992) found atmospheric pressure changes explained $40 \%$ of the variance in bubble flux from a low boreal beaver pond, and Mattson and Likens (1990) reported a significant correlation between bubble flux and atmospheric pressure at Mirror Lake, New Hampshire. Hydrostatic pressure caused 
by tidal cycles has been identified as the primary control of bubbling in a freshwater subtidal wetland (Chanton et al., 1989) and in coastal marine sediments (Martens and Klump, 1980).

Water level was not a significant predictor of flux although the sudden drop in water level caused by dam failure on June 22 (J.d. 174) was associated with an increase in bubble flux. The maximum 24-hour change in water level $(-8.8 \mathrm{~cm})$ is equivalent to a decrease in atmospheric pressure of $0.86 \mathrm{kPa}$. Based on the midseason regression equation of atmospheric pressure vs. open water bubble flux, this change should cause an increase in bubble flux of $109.5 \mathrm{mg} \mathrm{CH}_{4} \mathrm{~m}^{-2} \mathrm{~d}^{-1}$. The observed changes were lower: the 24-hour changes in mean bubble flux from open water sites ranged from 8 to $101 \mathrm{mg} \mathrm{CH}_{4} \mathrm{~m}^{-2} \mathrm{~d}^{-1}$ in the 3 days following dam failure. The smaller change in flux is likely due to the lower sediment temperatures and less antecedent $\mathrm{CH}_{4}$ storage since the dam failure occurred early in the season. The drop in water level was also concurrent with an increase in sediment temperature and was accompanied by a decrease in atmospheric pressure; therefore it is difficult to determine to what degree the changes in temperature and pressure each affected flux.

Wind velocity was not related to bubble fluxes but on one extremely windy day (J.d. 236), high fluxes of $\mathrm{CH}_{4}$ were observed due to wind-driven turbulence in the water column that likely disturbed the sediments and caused bubble release. 


\subsection{4_Secondary Controls on CH. Release: Plant Transport}

There was no evidence of plant-enhanced transport of ${ }^{2} H_{4}$ by most plant species at the beaver pond, but the chamber flux measurements were prone to the same problem as described earlier for ('arex sites. Certain species of apuatic emergent plants have been found to ventilate $\mathrm{CH}_{4}$ from the sediments to the atmosphere, although the mechanism involved probably differs between plant species (see Chanton and Dacey, 1991). Although very few lloating chamber measurements were taken ove, Typha $(\mathrm{n}=4)$, the leaf areas enclosed were relatively large, and these fluxes were much higher than adjacent open water fluxes. High $\mathrm{Cl}_{1}$ fluxes from Typha sy. have been documented in other studies (Sebacher et al., 1985.). Plant enhanced $\mathrm{CH}_{4}$ transport has also been shown for Nymphatu sp. (Sebacher et al., 1985), but was not found here, probably because the plants were small and only 1 plant was enclosed in each chamber.

Plant-enhanced transport might explain the observed differences in bubble flux and $\mathrm{CH}_{4}$ concentrations in bubbles between open water and vegetated sites. If emergent macrophytes relieve the pressure of $\mathrm{CH}_{4}$ in sediments, then less $\mathrm{CH}_{4}$ will accumulate and lower bubble emissions will result at vegetated sites. Furthermore, if bubbles strip $\mathrm{N}_{2}$ from the sfdiments, then areas with intense bubbling rates will release bubbles with less $\mathrm{N}_{2}$ and relatively more $\mathrm{CH}_{4}$. Studies in other flooded wetlands have illustrated these points. In estuarine North Carolina sediments (Chanton et al., 1989), and Alaskan tundra wetlands (Martens et al., 1992), open water sites sustained higher bubble fluxes and released bubbles with higher $\mathrm{CH}_{4}$ concentrations than vegetated 
sites. At high bubbling rates, more $\mathrm{N}_{2}$ was stripped from the sediments and this rate of removal exceeded the rate of $\mathrm{N}_{2}$ resupply by molecular diffusion from the atmosphere. At sites vegetated by emergent macrophytes, the bubble flux was lower because the plants acted as conduits for $\mathrm{CH}_{4}$ transport, less stripping of $\mathrm{N}_{2}$ occured, and diffusive resupply maintained $\mathrm{N}_{2}$ concentrations in bubbles. Bubbles from vegetated sites therefore contained more $\mathrm{N}_{2}$ and less $\mathrm{CH}_{4}$ than open water sites.

Holtzapfel-Pshorn and Seiler (1986) illustrated how the emergence of vegetation can shift the dominant mode of $\mathrm{CH}_{4}$ transport within a site from ebullition to ventilation by plants. $\mathrm{CH}_{4}$ transport was predominantly by ebullition when the rice plants were below the water surface, but after emerging, the transport was primarily through their stems. Plant transport reduced porewater $\mathrm{CH}_{4}$ concentrations and cbullition ceased.

The relationship between bubbling rate and the ratio of $\mathrm{N}_{2}: \mathrm{CH}_{4}$ in bubbles is supported here. Although $\mathrm{N}_{2}$ in bubbles was not measured, a positive relationship was observed between bubbling rate and bubble $\mathrm{CH}_{4}$ concentration (Fig. 4.8). Plant transport may not be responsible for this relationship, however, since stripping of $\mathrm{N}_{2}$ by bubbles may occur universally. Moreover, the plant transport hypothesis is not supported by $\mathrm{CH}_{4}$ storage inventories in the pond. Storage of dissolved $\mathrm{CH}_{4}$ was similar at the three piezometer nests, and bubble storage (determined once) was similar at a deep open water site and a shallow vegetated site. Bubble and dissolved storages were not determined at the same site, but have been shown to be maintain equilibrium (Chanton et al., 1989). If plant transport releases $\mathrm{CH}_{4}$ in sediments, then both lower 
a)

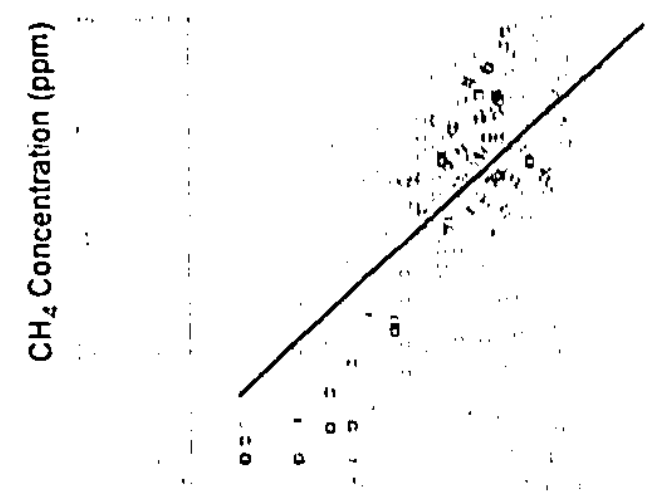

Bubbling Rate $\left(\mathrm{ml} \mathrm{m}^{2} \mathrm{~d}^{\prime}\right)$

b)
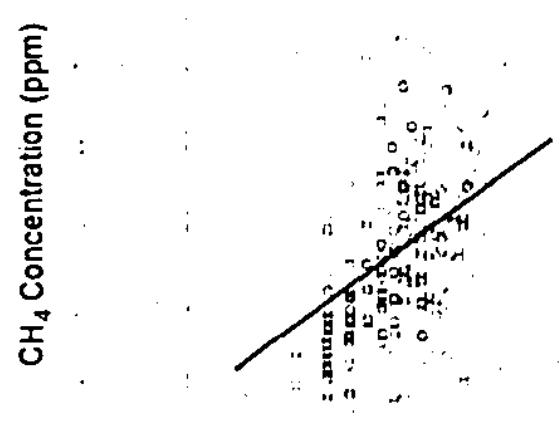

Bubbling Rate $\left(\mathrm{ml} \mathrm{m}^{-2} \mathrm{~d}^{\cdot 1}\right)$

Fig. 4.8: Bubbling Rate vs. $\mathrm{CH}_{4}$ Concentration at a) Open Water and b) Vegetated Sites 
dissolved and bubble storage should be evident at vegetated sites. Although planttransport is suspected in this pond, further investigation is required to determine the importance of this mechanism. It should be emphasized that since most beaver ponds are largely unvegetated, the $\mathrm{CH}_{4}$ flux through plants will be less important than the flux transported by bubbles and diffusion on a regional scale.

\subsection{C.H, Dynamics in the Beaver Pond}

In the previous section, the factors controlling $\mathrm{CH}_{4}$ availability and release were identified. These factors explain some of the flux variability, but do not explain intersite flux differences. In this section, the processes of $\mathrm{CH}_{4}$ production, oxidation and storage are addressed. The evidence for the relative importance of each is examined, and quantified where possible. Differences in these processes appear to control the differences in $\mathrm{CH}_{4}$ flux from vegetated and open water areas of the pond.

\subsubsection{Storage}

Storage of $\mathrm{CH}_{4}$ in the sediments may conceal the relationships between production, oxidation, and flux. Storage can delay the release of $\mathrm{CH}_{4}$, but if release from storage is triggered (by external factors), very large emissions may result because the sediment $\mathrm{CH}_{4}$ reservoir is large. However, in mid-season (J.d. 170- 252), the amount of $\mathrm{CH}_{4}$ stored remained relatively constant; 24-hour changes in porewater $\mathrm{CH}_{4}$ storage were rarely greater than $10 \%$. The observed bubble flux comprised only a small portion of the sediment $\mathrm{CH}_{4}$ reservoir (4-6\%), therefore even large bubble 
emissions resulted only in small decreases in the amount of CH. stored (Section 3.3.4). Since storage was at steady-state, changes in flux should be directly related to changes in $\mathrm{CH}_{4}$ production and oxidation processes. Furthermore, there was no significant difference in the mass of $\mathrm{CH}_{4}$ stored between vegetated and open water areas of the pond (Section 3.7). Therefore, differences in the $\mathrm{CH}_{4}$ flux between vegetated and open water areas should also be related to differences in the $\mathrm{CH}_{4}$ production and oxidation processes between sites.

\subsection{2 $\mathrm{CH}_{4}$ Production}

$\mathrm{CH}_{4}$ production had to be greater than oxidation because the beaver pond was a net source of $\mathrm{CH}_{4}$ to the atmosphere. This beaver pond was found to be a relatively large source of $\mathrm{CH}_{4}$ compared to other wetlands in the same region, probably because conditions in the pond promoted $\mathrm{CH}_{4}$ production and minimized $\mathrm{CH}_{4}$ oxidation.

Although absolute in siln rates of production and oxidation were not determined, the relative importance of each can be estimated.

As described above (Section 3.4.1), the in sill oxidation-inhibition experiments were used to estimate $\mathrm{CH}_{4}$ production rates, but these results may not be reliable because of the small sample size and large standard error. Maximum rates of production for the beaver pond may be estimated, however, as the midseason net flux from open water sites. Open water sites sustained high bubble fluxes, and midseason porewater storage was constant. Peeper $\mathrm{CH}_{4}$ profiles, dissolved $\mathrm{O}_{2}$ profiles, and open water productivity measurements indicate that the potential for $\mathrm{CH}_{4}$ oxidation was low 
at these sites (see Section 4.4.3); therefore, production rates likely equalled the flux from these sites. Similarly, in productive unvegetated sediments at Cape Lookout Bight, North Carolina, Crill and Martens (1983) determined that $\mathrm{CH}_{4}$ storage was saturated and ebullition rates were equal to $\mathrm{CH}_{4}$ production in the sediments. Rates of $\mathrm{CH}_{4}$ production from these deep open water sites can, therefore, be estimated as the midseason (J.d. 194 to 220) mean net flux of $452 \pm 130 \mathrm{mg} \mathrm{CH}_{4} \mathrm{~m}^{-2} \mathrm{~d}^{-1}$.

The large and consistent difference in bubble flux between open water and vegetated sites, despite similar storage reservoirs, suggests that differences in $\mathrm{CH}_{4}$ production and/or oxidation occur between these two types of sites. Differences were found in the isotopic composition of $\mathrm{CH}_{4}$ in bubbles between vegetated and open water areas of the pond. Differences in carbon $(\mathrm{C})$ and hydrogen $(\mathrm{H})$ isotopes in emitted $\mathrm{CH}_{4}$ may result from different processes (i.e. chemical pathways) by which $\mathrm{CH}_{4}$ is produced, and by oxidative processes. Fractionation of both $\mathrm{C}$ and $\mathrm{H}$ isotopes occurs during methanogenesis, but the degree of fractionation differs according to the pathway involved (Whiticar et al., 1986; Burke et al., 1988; Happell et al., 1993). Isotopic fractionation also occurs during oxidation, but is distinguishable from the fractionation caused by $\mathrm{CH}_{4}$ production (Coleman et al., 1981). No fractionation occurs during bubble transport itself (Martens et al., 1986; Chanton and Martens, 1988).

During acetate fermentation, in which $\mathrm{CH}_{4}$ is derived from methyl groups, $\mathrm{CH}_{4}$ becomes enriched in ${ }^{13} \mathrm{C}$ and depleted in $\mathrm{D}$ (deuterium). During $\mathrm{CO}_{2}$ reduction, in which hydrogen is used as the electron source, $\mathrm{CH}_{4}$ becomes relatively depleted in ${ }^{13} \mathrm{C}$ 
and enriched in D. During Cll, oxidation, however, methanotrophs preferentially consume the lighter isotopes of both $\mathrm{C}$ and $\mathrm{H}$, and the remaining $\mathrm{CH}_{4}$ will be enriched in ${ }^{13} \mathrm{C}$ and $\mathrm{D}$. Plots of the relative abundance of the light vs. heavy isotopes in emitted or stored $\mathrm{CH}_{4}$ can illustrate trends in the importance of these processes between different areas (sce Fig. 3.21).

The graph of the isotopic composition of $\mathrm{CH}_{4}$ released in bubbles shows that $\mathrm{CH}_{4}$ emitted from open water sites is isotopically heavier in $\mathrm{H}$, but lighter in $\mathrm{C}$, compared to $\mathrm{CH}_{4}$ emitted from sites vegetated with emergent macrophytes. This difference is consistent with a difference in $\mathrm{CH}_{4}$ production pathway. At open water sites, the released $\mathrm{CH}_{4}$ resembles that produced by $\mathrm{CO}_{2}$ fermentation, while the $\mathrm{CH}_{4}$ in bubbles from vegetated areas is produced more by acetate reduction. Therefore, the dominant substrate used by methanogens differs between sites. This difference may account for the difference in total emissions. In open water areas, $\mathrm{CO}_{2}$ is produced during decomposition of organic matter, and is abundantly available since the beaver pond was determined to be a large source of $\mathrm{CO}_{2}$ to the atmosphere ( $\mathrm{N}$. Roulet, unpubl. data). In vegetated areas, acetate is the main substrate for $\mathrm{CH}_{4}$ production. Acetate may also be available in smaller quantities than $\mathrm{CO}_{2}$ due to competition from other methanogens and limited supply by plants (J. Chanton, personal communication). Therefore $\mathrm{CH}_{4}$ production rates may be lower in vegetated areas than open water areas.

The difference in flux due to production is supported by two measurements of ${ }^{14} \mathrm{C}$ signatures in sediment samples from open water and vegetated areas of the pond 
(S. Trumbore, unpubl. data). Measurements are reported as ratios relative to 1950 oxalic acid (ratio $=1 ; \delta^{14} \mathrm{C}=0 \%$ ) (S. Trumbore, personal communication). Negative $\mathrm{o}^{1.4} \mathrm{C}$ values result where significant decay of ${ }^{1.4} \mathrm{C}$ has occurred (ratio $<1 ; \delta^{1.4} \mathrm{C}<0 \%$ ), but positive values of $\delta^{14} \mathrm{C}$ will only result when a more recent source of ${ }^{14} \mathrm{C}$ is present (ratio $>1 ; \delta^{14} \mathrm{C}>0 \%$ ). This new source is bomb ${ }^{14} \mathrm{C}$, produced by weapons testing. Since most bomb ${ }^{14} \mathrm{C}$ was released in the $1960 \mathrm{~s}$, a $\delta^{14} \mathrm{C}>0 \%$ value indicates that a significant amount of ${ }^{14} \mathrm{C}$ in the sample has been derived from carbon fixed from the atmosphere by plants during the past 30 years.

Both measurements of ${ }^{14} \mathrm{C}$ indicated that the carbon in beaver pond sediments have been fixed since the 1960s. However, the sediments from a vegetated area of the beaver pond contained newer carbon ( $\mathrm{del}^{14} \mathrm{C}=6.49 \%$ ) than sediments from an open water area $\left(\mathrm{del}^{14} \mathrm{C}=7.37 \%\right.$ ). This result is consistent with the hypothesis that more new carbon compounds produced by plants (e.g. acetate) support the populations of methanogens at vegetated sites, and that older peat materials (containing $\mathrm{CO}_{2}$ ) supply substrates for methanogenesis at open water sites.

Studies of other ebullition-dominated systems found similar $\mathrm{CH}_{4}$ production differences between vegetated and open water areas (Martens et al., 1986; Burke et al., 1988; Chanton and Martens, 1988). Acetate reduction was found to be relatively more important in summer months, suggesting that temperature or substrate availability connected with plant activity may control the relative rates of the two production pathways. 
This explanation for the observed bubble flux difference differs from that provided above (Section 4.3.4), in which it was explained that the lower bubble tlux in vegetated areas may be due to ventilation of $\mathrm{CH}_{4}$ in sediments by plants. These two explanations are not exclusive, however, and may act in combination to produce the observed flux. Since vegetative transport of $\mathrm{CH}_{4}$ was not demonstrated, the relative contributions of the two mechanisms remain unclear.

The isotopic evidence that production pathways differed also does not preclude a difference in $\mathrm{CH}_{4}$ oxidation rates between vegetated and non-vegetated sites. Oxidation of $\mathrm{CH}_{4}$ may also occur, and rates may differ between areas of the pond. However, the dominant fractionation effect appears to be caused by differences in the $\mathrm{CH}_{4}$ production pathways, and any isotopic effects of oxidation are obscured by this difference. If the difference in bubble $\mathrm{CH}_{4}$ flux between vegetated and open water sites were predominantly due to greater oxidation of $\mathrm{CH}_{4}$ at vegetated sites, however, the fitted line through the isotope data would have a positive slope (see Fig. 3.21).

\subsection{3 $\mathrm{CH}_{4}$ Oxidation}

Evidence exists to indicate that some oxidation occurs in the beaver pond. $\mathrm{CH}_{4}$ consumers (methanotrophs) are obligate aerobes, and will be present in greatest numbers at the anaerobic-aerobic interface where both $\mathrm{CH}_{4}$ and $\mathrm{O}_{2}$ are present in optimal quantities (King, 1990; Knowles, 1993). The availability of sufficient $\mathrm{CH}_{4}$ in this beaver pond has been well established (e.g. see sediment profiles, Section 3.5), but the location of the anaerobic-aerobic interface is not known. Three lines of evidence 
may be used to indicate the importance of $\mathrm{CH}_{4}$ oxidation in the sediments and water column: (1) low open water productivity indicates that little oxidation occurs in the water column; (2) profiles of dissolved oxygen show that $\mathrm{O}_{2}$ is available at the sediment-water interface, but may be rapidly consumed by the competing processes of $\mathrm{CO}_{2}$ production and $\mathrm{CH}_{4}$ oxidation; and (3) peeper profiles, incubations and oxidation-inhibition experiments indicate that some $\mathrm{CH}_{4}$ oxidation occurs, especially in surficial sediments at vegetated sites, but in sitn rates are probably low.

Differences between benthic chamber fluxes and floating chamber fluxes (Section 3.4.1) indicated that oxidation of $\mathrm{CH}_{4}$ in the water column depletes the flux at a mean rate of $43.5 \mathrm{mg} \mathrm{CH}_{4} \mathrm{~m}^{-2} \mathrm{~d}^{-1}$. While this provides indirect evidence for oxidation, intersite variability and differences between benthic and floating chamber measure nent techniques (including disturbance of sediments during benthic sampling) may account for the flux difference. Furthermore, open water productivity was low, indicating that $\mathrm{CH}_{4}$ oxidation in the water column is likely insignificant in the pond.

46 samples of water from 13 NSA beaver ponds were collected for chlorophyll a analysis ( $R$. Bourbonniere, unpubl. data). From June through August, all values of chlorophyll a (corrected for the biodegradation product phaeophytin) were low (range $<1$ to $2 \mu \mathrm{g}$ chlorophyll a $\mathrm{L}^{-1}$ water). In late August and early September, concentrations had increased to much higher levels (range 6-24 $\mu \mathrm{g} \mathrm{L}^{-1}$ ), presumably because macrophyte fragments in the waters contributed to the chlorophyll a content (R. Bourbonniere, personal communication). The concentration of chlorophyll a was only tested once in the beaver pond examined in this study (Sept. 12), and the 
concentration was low $\left(3.0 \mu \mathrm{g} \mathrm{L}{ }^{-1}\right)$, indicating that little open water photosynthesis occurs in the pond. Since little $\mathrm{O}_{2}$ is produced, $\mathrm{CH}_{4}$ oxidation in the water column is likely negligible.

Profiles of temperature indicate that the pond was not stratified, but dissolved oxygen concentrations decreased markedly with depth (Fig. 4,9) (R. Bourbonniere, unpubl. data). The $\mathrm{O}_{2}$ profile resembles the clinograde profile found in productive lakes (Wetzel, 1983), and indicates there is a large sink for $\mathrm{O}_{2}$ at depth. $\mathrm{O}_{2}$ is most depleted near the sediment-water interface, where bacterial decomposition of sedimenting organic matter is greatest. The $\mathrm{CO}_{2}$ flux from this beaver pond is high and is probably due to heterotrophic respiration in the sediments (N. Roulet, unpubl. data). Since respiration also requires $\mathrm{O}_{2}$, oxygen availability will be limited by the competing demands of decomposers and methanotrophs. $\mathrm{CH}_{4}$ oxidation may in turn be limited by $\mathrm{O}_{2}$ availability.

Although dissolved $\mathrm{O}_{2}$ concentrations were low or below detectable limits in bottom waters, the presence of sediment algal mats, even in the deepest areas of the pond, indicates that $\mathrm{O}_{2}$ is produced at the sediment surface. Calculations of PAR attenuation in the water column indicated that optimal photosynthetic activity for algat (at $1 \%$ incident PAR; Wetzel, 1983) occurs at an average depth of $1.2 \mathrm{~m}$. Since most of the pond is shallower than $1.2 \mathrm{~m}$, the majority of the pond sediments receive sufficient light to sustain algal production throughout the season. However, the amount of $\mathrm{O}_{2}$ that is produced by epiphytic algae is probably small compared to that transported from the atmosphere by convective mixing, and it will also be consumed 

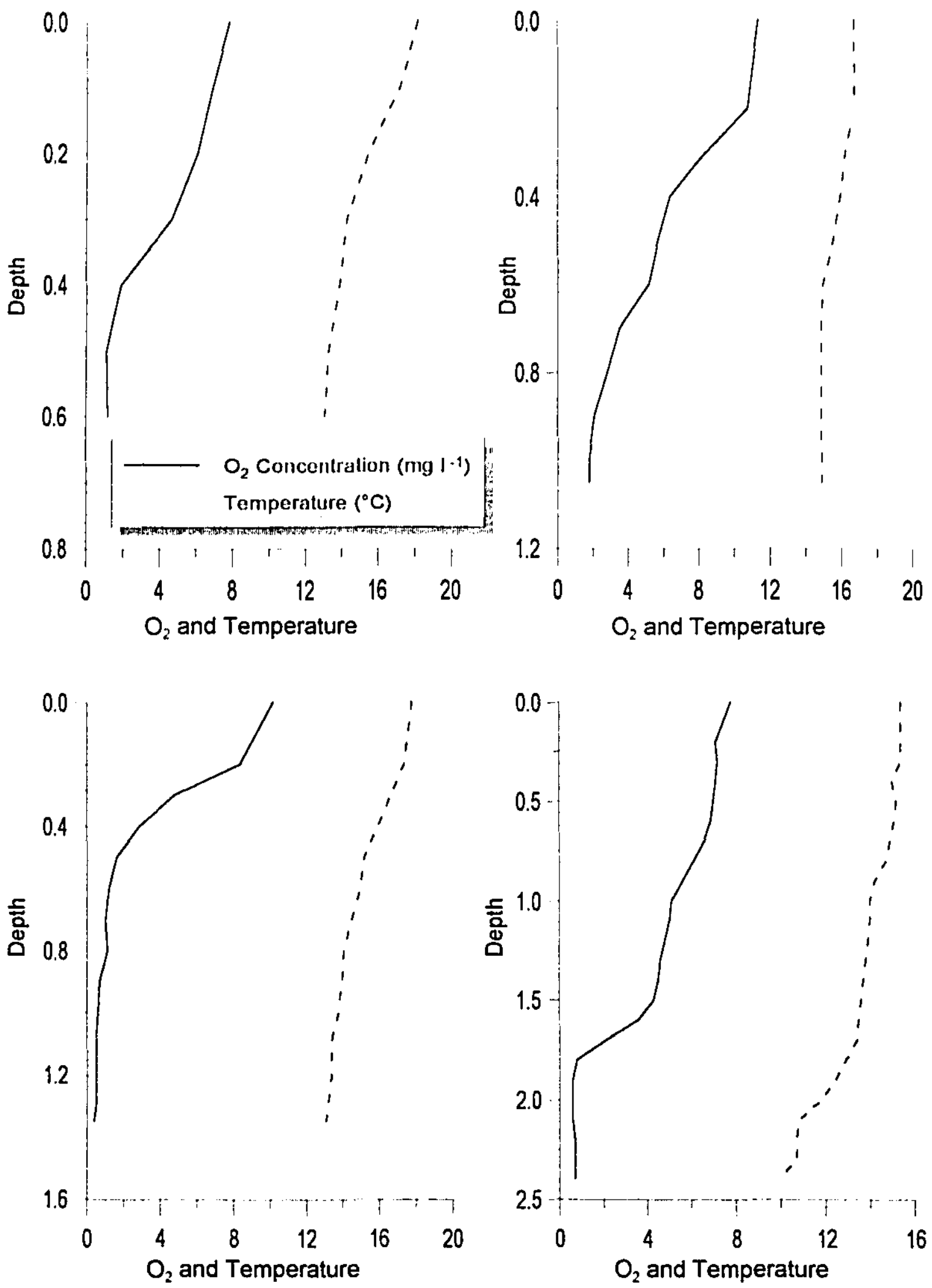

Fig. 4.9: Water Column Profiles of $\mathrm{O}_{2}$ and Temperature from the Beaver Pond Late August, 1994 (R. Bourbonniere, unpubl. data) Legend applies to all figures 
by competing processes of $\mathrm{CO}_{2}$ production and $\mathrm{CH}_{4}$ oxidation. Even low concentrations of $\mathrm{O}_{2}$ may be sufficient for $\mathrm{CH}_{4}$ oxidation (King, 1992), however, and some $\mathrm{CH}_{4}$ oxidation likely occurs although in situ rates remain uncertain.

Profiles of sediment $\mathrm{CH}_{4}$ concentrations indicated that significant consumption of $\mathrm{CH}_{4}$ occurs within the upper layers of the beaver pond sediments (cl. Yavitt et al., 1992). $\mathrm{CH}_{4}$ concentrations in surface layers were commonly $20 \%$ of concentrations in deeper sediments, but $\mathrm{CH}_{4}$ production potentials determined under anaerobic conditions in the laboratory were similar with depth. Since the surface sediments are equally capable of producing $\mathrm{CH}_{4}$, the reduction of $\mathrm{CH}_{4}$ concentrations near the sediment-water interface is likely due to oxidation of $\mathrm{CH}_{4}$, and not merely due to bulk flow of $\mathrm{CH}_{4}$ from the sediments. Consumption potentials were also greatest in surface sediments, indicating that the greatest numbers of methanotrophs inhabit these layers (cf. Sundh et al., 1995).

The oxidation zone appeared to be extend deeper at shallow water sites than deep water sites (Section 3.5 ). $\mathrm{O}_{2}$ concentrations were slightly higher in bottom waters at shallow sites ( $R$. Bourbonniere, unpubl. data), probably because atmospheric $\mathrm{O}_{2}$ can be effectively transported by convection to shallow depths, and because $\mathrm{O}_{2}$ is transported to the sediments by aquatic plants growing at shallow sites in the pond. Incubation experiments yielded the highest potential oxidation rates from a vegetated floating mat. Therefore, higher rates of $\mathrm{CH}_{4}$ consumption likely occur in shallow, vegetated areas of the beaver pond. 
Other researchers (Yavitt et al., 1992) have used benthic chambers to measure fluxes of $\mathrm{CH}_{4}$ across the sediment-water interface, and compared these with $\mathrm{CH}_{4}$ production rates measured in the laboratory to calculate oxidation rates. However, incubation experiments do not accurately simulate field conditions; instead they indicate potential rates of $\mathrm{CH}_{4}$ production (cf. Sundh et al., 1995). In situ rates of $\mathrm{CH}_{4}$ oxidation are extremely difficult to obtain. Separation of production and oxidation components of flux requires the use of oxidation inhibitors, all of which may have side effects. For example, picnolinic acid may be toxic to plants and methanogens (Bédard and Knowles, 1989; Epp and Chanton, 1993). Methyl fluoride (MF) was used here to inhibit populations of methanotrophs in benthic chambers because it is reportedly non-toxic to plants and does not interfere with methanogenesis at low MF concentrations (Oremland and Culbertson, 1992; Epp and Chanton, 1993). Oxidation was calculated by difference between fluxes measured in benthic chambers where MF was used, and fluxes measured without the inhibitor.

The results indicated that oxidation reduced the flux of $\mathrm{CH}_{4}$ across the sediment-water interface. The results are tenuous due to small sample sizes and large standard deviations, but they indicate that $\mathrm{CH}_{4}$ oxidation was occuring, at least at the sites (depth $<1 \mathrm{~m}$ ) where the sampling was performed. Quantitative interpretation of the results is not possible because complete inhibition of oxidation was probably not achieved. Successful inhibition of methanotrophs with MF may have occurred within the benthic chamber, but MF was likely restricted from diffusing far into the sediments because the fluxes were measured immediately after chamber and MF deployment. 
MF is extremely soluble $\left(=1.7 \mathrm{ml} \mathrm{MF} \mathrm{ml^{-1 }} \mathrm{H}, \mathrm{O} ;\right.$ Oremland and Culbertson, 1992) and probably remained in the water within the benthic chamber. Because some portion of the methanotrophs was probably not inhibited, a significant but unknown amount of oxidation may still have occurred.

Production potentials determined in anaerobic incubations were similar to $\mathrm{CH} . \mathrm{.}$ production potentials determined in a wide range of peat samples from saturated wetlands in the Hudson Bay lowlands (Moore et al., 1994). Oxidation potentials from the floating mat site were also similar or greater than the oxidation potentials from these peats, but the open water sites displayed much lower consumption potentials, especially in core 3 which was obtained from a deep water, high flux, site.

Unfortunately, oxidation potentials are not directly comparable across studies since they depend on the initial concentration of $\mathrm{CH}_{4}$ available in the sediment slurry. These results indicate, however, that since production rates were similar, the high flux of $\mathrm{CH}_{4}$ from the beaver pond probably resulted from low potential to oxidize the produced $\mathrm{CH}_{4}$, especially in silu where oxidation is limited by anaerobic conditions.

\subsection{Summary and Conclusions}

The mean net flux of $\mathrm{CH}_{4}$ from this beaver pond $\left(320 \mathrm{mg} \mathrm{m}^{-2} \mathrm{~d}^{-1}\right.$ and $155 \mathrm{mg}$ $\mathrm{m}^{-2} \mathrm{~d}^{-1}$, for open water and vegetated sites, respectively) was greater than the flux from most other northern study area wetland sites. Confidence in the measured flux is high because large sample sizes were obtained, and because the net $\mathrm{CH}_{4}$ flux is confirmed by independent measurements by a different method at the same site. A large proportion of the total $\mathrm{CH}_{4}$ flux was released by ebullition, and future studies in 
flooded wellands should meatsure bubbles separately if floating chambers are employed.

It was initially hypothesized that the beaver pond would sustain high $\mathrm{CI}_{4}$ emissions because factors in the pond maximize $\mathrm{CH}_{4}$ production and minimize oxidation. Indeed, high sediment temperatures promoted $\mathrm{CH}_{4}$ production, and inundation restricted oxidation. Oxidation of $\mathrm{CH}_{4}$ occured at the sediment water inlerface, but was limited by $\mathrm{O}_{2}$ availability. Oxidation in the water column was determined to be negligible.

The differences in $\mathrm{CH}_{4}$ availability and transport between open water and vegetated sites, and the factors which controlled these processes, are shown in Fig. 4.10. The diffusive flux was similar at open water and vegetated sites. The factors that controlled the diffusive flux were sediment temperature (by controlling $\mathrm{CH}_{4}$ availability) and windspeed (by controlling transport). Bubble flux from open water sites was twice that from vegetated sites, because $\mathrm{CH}_{4}$ availability was greater in open water areas. The dominant pathway for $\mathrm{CH}_{4}$ production was $\mathrm{CO}_{2}$ fermentation at open water sites, and acetate reduction at vegetated sites. The lower flux observed from vegetated sites may have resulted from limited acetate availability, and greater oxidation. In addition, plants may have enhanced $\mathrm{CH}_{4}$ transport, thus reducing porewater $\mathrm{CH}_{4}$ concentrations, although porewater storage was similar between sites. The role of emergent plants in transporting $\mathrm{CH}_{4}$ remains unclear, but since most beaver ponds probably comprise open water, plant transport may be insignificant at a regional scale. 


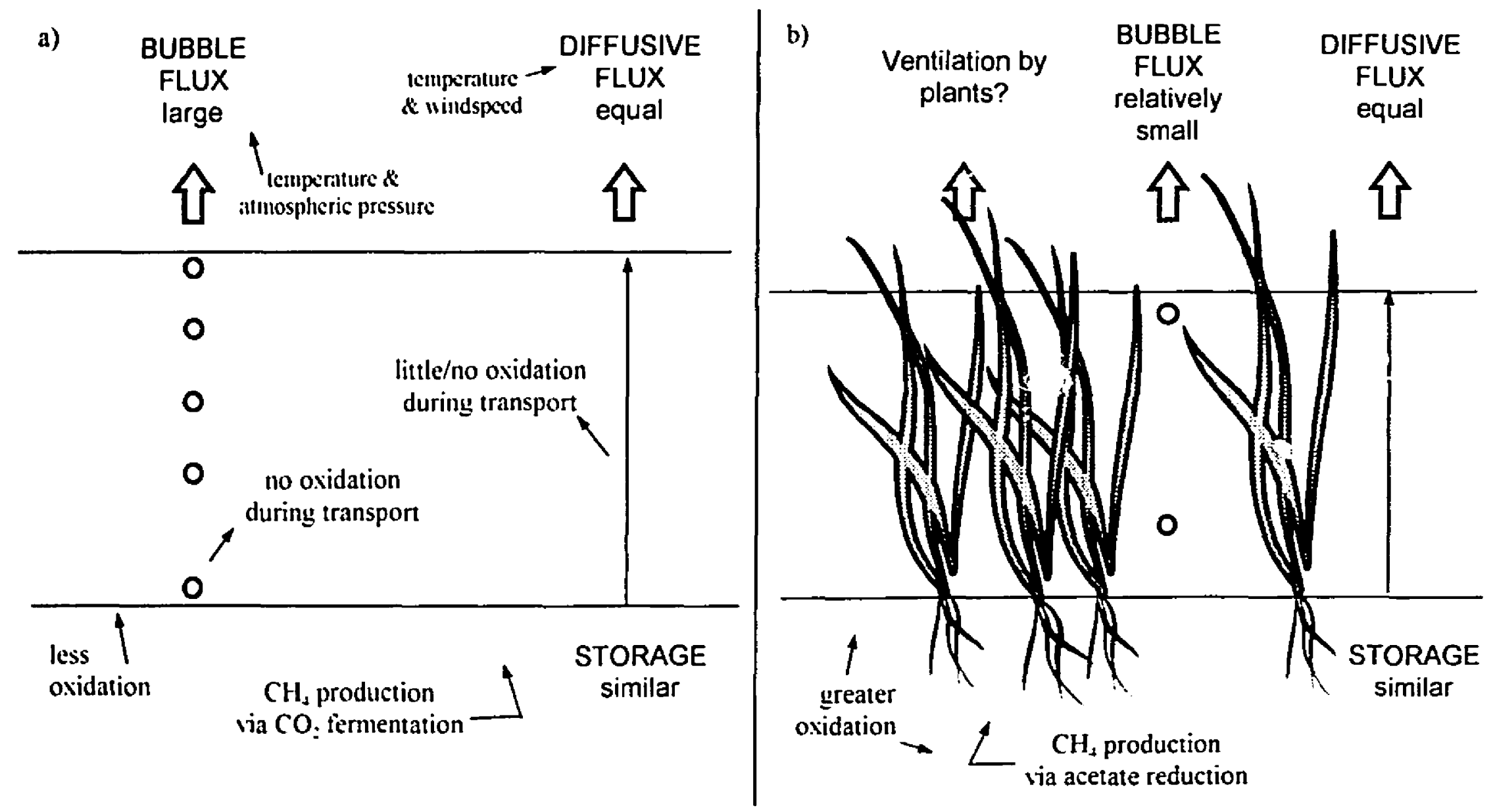

Fig. +10 . Methane Dynamics in a Northem Boreal Beaver Pond at a) open water sites and b) sites vegetated with emergent aquatic plants 
labullition of $\mathrm{CH}_{4}$ was found to be a significant transport mechanism, comprising 20 and $52 \%$ of the total flux, depending on site. The amount of $\mathrm{CH}_{4}$ available for ebullition was controlled by sediment temperature, and bubble release was controlled by atmospheric pressure. Large water level changes also affected bubble transport. Bubble flux was not related to the loss of $\mathrm{CH}_{4}$ stored in the sediments, probably because fluxes were small relative to the stored reservoir of $\mathrm{CH}_{4}$.

Most regional and global $\mathrm{CH}_{4}$ budgets have neglected beaver ponds. The results from this study, however, indicate that beaver ponds are disproportionately high emitters of $\mathrm{CH}_{4}$. The budget presented above (Section 4.1.2) illustrates the large effect that beaver ponds play in determining the net regional flux of $\mathrm{CH}_{4}$. With increasing knowledge about the flux of $\mathrm{CH}_{4}$ and its variability from beaver ponds, the areal extent of ponds will be the greatest potential error in determining their contribution to regional flux. 


\section{References Cited}

Aselmann, I, and P.J. Crutzen, 1989, Global distribution of vatural freshwater wetlands and rice paddies, their net primary productivity, sensonality and possible methane emissions, J. Alm. (' $/ \mathrm{hem} .8: 307-358$.

Bartlett, K.B. and R.C. Harriss, 1993, Review and assessment of methane emissions from wetlands, ('hemosphere' 26: 201-320.

Bédard, C. and R. Knowles, 1989, Physiology, biochemistry, and specific inhibitors of $\mathrm{CH}_{4}, \mathrm{NH}_{4}{ }^{\prime}$, and $\mathrm{CO}$ oxidation by methanotrophs and nitrifiers, Microh. Revi'ws 53: 68-84.

Bubier, J., A. Costello, T.R. Moore, N.T. Roulet, and K. Savage, 1993 , Microtopography and methane flux in boreal peatlands, northern Ontario, Canada, (an. J. Bot. 71: 1056-1063.

Bubier, J.L., T.R. Moore, L. Bellisario, N.T. Comer and P.M. Crill, 1995a, Ecological controls on methane emissions from a northern peatland complex in the zone of discontinuous permafrost, Manitoba, Canada, (ilobal Biogeochem. ('yc/es 9(4): 455470 .

Bubier, J.L., T.R. Moore and S. Juggins, 1995b, Predicting methane emission from bryophyte distribution in northern Canadian peatlands, licology' 76(3): 677-693.

Burke, R.A., C.S. Martens and W.M. Sackett, 1988, Seasonal variations of D/H and ${ }^{13} \mathrm{C} /{ }^{12} \mathrm{C}$ ratios of microbial methane in surface sediments, Nature 332: 829-831.

Chanton, J.P. and J.W.H. Dacey, 1991, Effects of vegetation on methane flux, production and sedimentary reservoirs, Chapter 3 in Trace (jas limissioms by Plamts, edited by H. Mooney, E. Hooland, and T. Sharkey, Academic Press, San Diego, Calif.

Chanton, J.P. and C.S. Martens, 1988, Seasonal variations in ebullitive flux and carbon isotopic composition of methane in a tidal freshwater estuary, (iloh. Biogeochem. Cycles 2(3): 289-298.

Chanton, J.P., C.S. Martens, and C.A. Kelley, 1989, Gas transport from methanesaturated, tidal freshwater and wetland sediments, l.imnol. Oceanogr. 34: 807-819.

Chanton, J.P., Whiting, G.J., Showers, W.J., and P.M. Crill, 1992, Methane flux from Peltandra virginica: Stable isotope tracing and chamber effects, (Blohal Bioggeochem. Cycles 6(1): 15-31

Cicerone, R.J., and R.S. Oremland, 1988, Biogeochemical aspects of atmospheric methane, Glohal Biogeochem. Cycles 2(4): 299-327. 
Coleman, D.I)., J.B. Risattc, and M. Schocll, 1981, Fractionation of carbon and hydrogen isotopes by methane oxidizing bacteria, (ieochim. ('osmochim. Acta 45: 1033-1037.

Crill, P.M., Bartlett, K.B., Harriss, R.C., Gorham, E., Verry, E.S., Sebacher, D.l., Madzar, L., and W. Sanner, 1988, Methane flux from Minnesota peatlands, (ilohell Biogyeochem. (ycles 2(4): 371-384.

Crill, P.M. and C.S. Martens, 1983, Spatial and temporal fluctuations of methane production in anoxic coastal marine sediments, Limmol. ()ceanogr. 28: 564-571.

Crill, P., 1991, Seasonal patterns of methane uptake and carbon dioxide release by a temperate woodland soil, (jlobal Biogeochem. (ycless 5(4): 319-334.

Dacey, J., 1980, Internal winds in water lilies: an adaptation for life in anaerobic sediments, Sicience 210(28): 1017-1019.

Dacey, J., and M.J. Klug, 1979, Methane efflux from lake sediments through water lilies, Science 203: 1253-1255.

Denmead, O.T. and J.R. Freney, 1992, Transfer coefficients for water-air exchange of ammonia, carbon dioxide and methane, ficol. Bull. 42: 31-41.

Dise, N.B., Gorham, E., and E.S. Verry, 1993, Environmental factors controlling methane emissions from peatlands in northern Minnesota, Jour. Geophys. Res. 98(D6): $10,583-10,594$

Dunfield, P., Knowles, R., Dumont, R., and T. Moore, 1993, Methane production and consumption in temperate and subarctic peat soils: response to temperature and $\mathrm{pH}$. Soil Biol. Biochem. 23: 321-326.

Epp. M.A. and J.P. Chanton, 1993, Rhizospheric methane oxidation determined via the methyl fluoride inhibition technique, J. Geophys. Res. 98(D10): 18,413-18,422.

Fechner, E.J. and H.F. Hemond, 1992, Methane transport and oxidation in the unsaturated zone of a Sphagnum peatland, Global Biogeochem. Cycles, 6(1): 33-44.

Ford. T.E. and R.J. Naiman, 1988, Alteration of carbon cycling by beaver: methane evasion rates from boreal forest streams and rivers, Can. J. Zool. 66: 529-533.

Fung, I., John, J., Lerner, J., Matthews, E., Prather, M., Steele, L., and P. Fraser, 1991, Global budgets of atmospheric methane: results from a three-dimensional global model synthesis. J. Geophys. Res. 96(D7): 13,033-13,065. 
Happell, J.D. and J.P. Chanton, 1993, Carbon remineralization in a north Florida swamp forest: effects of water level on the pathways and rates of soil organic matter decomposition, (ilohal Biogeochem. (yeles, 7(3): 475-490.

Happell, J.D., Chanton, J.P., Whiting, G.J., and W.S. Showers, 1993, Stable isotope tracing of methane dynamics in Everglades marshes with and without active populations of methane oxidizing bacteria, J. (icophys: Res. 98(D8): 14,771-14,782.

Hesslein, R.H., 1976, An in situ sampler for close interval pore water studies, limmol. ()'eanogr. 21: 912-914.

Holtzapfel-Pshorn, A. and W. Seiler, 1986, Methane emission during a cultivation period from an Italian rice paddy, .J. (ieophys. Res. 91 (DII): 11,803-11,814.

King, G.M., 1990, Regulation by light of methane emissions from a wetland, Nulurc 345: 513-515.

King, G.M., 1992, Ecological aspects of methane oxidation, a key determinant of global methane dynamics, Chapter 9 in Advances in Microbial licology, Vol. 12, edited by K.C. Marshall, Plenum Press, New York.

Knowles, R., 1993, Methane: Processes of production and consumption, Chapter 10 in Agricultural Ecosystem Iiffects on Trace (jases and (ilohal ('limate ( 'hange, American Society of Agronomy Special Publication no. 55, Madison, WI.

Lerman, A., 1979, Geochemical Processes: Water and Sediment linviromments, John Wiley and Sons, Inc.

Martens, C.S., N.E. Blair, C.D. Green, and D.J. Des Marais, 1986, Seasonal variations in the stable isotopic signature of biogenic methane in a coastal sediment, Science 233: 1300-1303.

Martens, C.S., C.A. Kelley, J.P. Chanton, and W.J. Showers, 1992, Carbon and hydrogen isotopic composition of methane from wetlands and lakes of the YukonKuskoswim Delta and the Alaskan tundra,.J. (jeophys: Res., 97(D15): 16,681-16,688.

Martens, C.S. and J.V. Klump, 1980, Biogeochemical cycling in an organic-rich coastal marine basin. 1. Methane sediment-water exchange process. (jeochim. Cosmochim. Acta 44: 471-490.

Matthews, E., 1994, Assessment of methane sources and their uncertainties in Assessment of uncertainties in the projected concentrations of methane in the atmosphere, Pure \& Appl. Chem. 66(I): 137-200. 
Mattson, M.D. and G.E. Likens, 1990, Air pressure and methane fluxes, Natture 347: 718-719.

Moore, T.R., 1988, Atmospheric methane, ('dll. (ieographer 32(2): 178-184.

Moore, T.R., A. Heyes, and N.T. Roulet, 1994, Methane emissions from wetlands, southern Hudson Bay lowland, .J. (jeophys. Res. 99(D1): 1455-1467.

Moore, T.R., and R. Knowles, 1989, The influence of water table levels on methane and carbon dioxide emissions from peatland soils, ('an. .J. Soil Sci. 69: 33-38.

Moore, T., Roulet, N., and R. Knowles, 1990, Spatial and temporal variations of methane flux from subarctic/northern boreal fens, Global Biogeochem. (ycles 4: 2946.

Moore, T.R., and N.T. Roulet, 1991, A comparison of dynamic and static chambers for methane emission measurements from subarctic fens, Atmosphere-()cean 29: 102109.

Moore, T.R., and N.T. Roulet, 1993, Methane flux:water table relations in northern wetlands, (ieophys. Res. Lett. 20(7): 587-590.

Moore, T.R., and N.T. Roulet, 1995, Methane emissions from Canadian peatlands, Chapter 12 in Soils and (ilobal Change, edited by R. Lal, J. Kimble, E. Levine and B.A. Stewart, Advances in Soil Science, CRC Press Inc.

Naiman, R.J., Johnston, C.A., and J.C. Kelley, 1988, Alteration of North American streams by beaver, BioScience 38(11): 753-762.

Naiman, R.J., T. Manning and C.A. Johnston, 1991, Beaver population fluctuations and tropospheric methane emissions in boreal wetlands, Biogeochemistry 12: 1-15.

Naiman, R.J., Melillo, J.M., and J.E. Hobbie, 1986, Ecosystem alteration of boreal forest streams by beaver (Castor canadensis), Ecology 67(5): 1254-1269.

Naiman, R.J., Pinay, G., Johnston, C.A., and J. Pastor, 1994, Beaver influences on the long-term biogeochemical characteristics of boreal forest drainage networks, Ecology 75(4): 905-921.

Nisbet, E.G., 1989, Some northern sources of atmospheric methane: production, history, and future implications, Can. J. Earth Sci. 26: 1603-1611.

Oremland, R.S. and C.W. Culbertson, 1992, Importance of methane-oxidizing bacteria in the methane budget as revealed by the use of a specific inhibitor, Nature 356: 421423. 
Rodhe, H., 1990, A comparison of the contribution of various gases to the greenhouse effect, Sicience 248: 1217-1219.

Roulet, N.T., Ash, R., and T.R. Moore, 1992, Low boreal wetlands as a source of atmospheric methane, Jour. (icophys. Res: 97(D4): 3739-3749.

Rudd., J.W. and C.D. Taylor, 1980, Methane cycling in aquatic environments, $A d$ : Aquat. Microbiol. 2: 77-150.

Sebacher, D.I., R.C. Harriss, and K.B. Bartlett, 1985, Methane emissions to the atmosphere through aquatic plants, J. Emviron. (2ual. 14:40-46.

Slanina, J., and P. Warneck, 1994, Introduction in Assessment of uncertainties in the projected concentrations of methane in the atmosphere, Pure \& Appl. ( $/ \mathrm{hem} .66(1)$ : 137-200.

Steele, L.P., Dlugokencky, E.J., Lang, P.M., Tans, P.P., Martin, R.C., and K.A. Masarie, 1992, Slowing down of the global accumulation of atmospheric methane during the 1980s, Nature 358: 313-316.

Sundh, I., Mikkelä, C., Nilsson, M., and B.H. Svensson, 1995, Potential aerobic methane oxidation in a Sphagnum-dominated peatland - controlling factors and relation to methane emission, Soil Biol. Biochem. 27(6): 829-837.

Svensson, B.H., 1984, Different temperature optima for methane formation when enrichments from acid peat are supplemented with acetate or hydrogen, Appl. lim. Microbiol. 48: 389-394.

Svensson, B.H., and I. Sundh, 1992, Factors affecting methane production in peat soils, Swo 43: 183-190.

Vitt, K.H., Bayley, S., Jin, T., Halsey, L., Barker, B., and R. Craik, 1990, Methame and Carbon Dioxide Production from Wetlands in Boreal Alherta, Report of Contract No. 90-0270, Alberta Fnvironment Ministry, Edmonton, Alberta.

Weyhenmeyer, C.E., 1992, Methane Emissions from a Boreal Beaver l'ond, M.Sc. Thesis, Trent University, Peterborough, Ontario.

Windsor, J., 1993, Methane Emissions from the Fastern Temperate Wetland Regiom and Spectral Characteristis of Subarctic liens, M.Sc. Thesis, McGill University, Montreal, Quebec.

Wetzel, R.G., 1983, Limmology, 2nd ed., Saunders College Publishing. 
Whalen, S.C. and W.S. Recburgh, 1990, Consumption of atmospheric methane by tundra soils, Netture 346: 160-162.

Whiticar, M.J. and E. Faber, 1985, Methane oxidation in sediment and water column environments - isotope evidence, $A d v$. Org. (ieoche'm. 10: 759-768.

Whiticar, M.J., E. Faber, and M. Schoell, 1986, Biogenic methane formation in marine and freshwater environments: $\mathrm{CO}_{2}$ reduction vs. acetate fermentation - isotope evidence, (jeochim. Cosmochim. Acta 50: 693-709.

Whiting, G.J. and J.P. Chanton, 1992, Plant-dependent $\mathrm{CH}_{4}$ emission in a subarctic Canadian fen, Cilobal Biogeochem. Cyc/es 6(3): 225-231.

Windsor, J., Moore, T.R., and N.T. Roulet, 1992, Episodic fluxes of methane from subarctic fens, Can. J. Soil. Sci. 72: 441-452.

Yavitt, J.B., G.E. Lang and A.J. Sextone, 1990, Methane fluxes in wetland and forest soils, beaver ponds, and low-order streams of a temperate forest ecosystem, .J. (ieophys. Res. 95(D|3): 22,463-22,474.

Yavitt, J.B. , L.L. Angell, T.J. Fahey, C.P. Cirmo, and C.T. Driscoll, 1992, Methane fluxes, concentrations, and production in two Adirondack beaver impoundments, Limnol. Oceanogr. 37(5): 1057-1066. 
Appendix I: Data Available through BORIS (BOREAS Information Systems)

Data are available, with special permission, from BOREAS Information Systems

(BORIS). Contact: J. Newcomber, NASA Goddard Space Flight Center, Greenbelt, Md. U.S.A.

\begin{tabular}{|c|c|c|}
\hline Data & Particulars & $\begin{array}{c}\text { Sample } \\
\text { Size }\end{array}$ \\
\hline \multirow[t]{2}{*}{ Chamber Flux Data } & $\begin{array}{l}\text { Individual Fluxes, date, time, site characteristics } \\
\text { (vegetation and depth of water) }\end{array}$ & 260 \\
\hline & Daily mean flux for 2 vegetation categories & $37-41$ \\
\hline $\begin{array}{c}\text { Surface Water } \\
\mathrm{CH}_{4} \text { Concentrations }\end{array}$ & $\begin{array}{l}\text { Surface water } \mathrm{CH}_{4} \text { concentrations, date, time, } \\
\text { windspeed, concurrent chamber flux, site characteristics }\end{array}$ & 141 \\
\hline \multirow[t]{2}{*}{ Bubble Flux Data } & $\begin{array}{l}\text { Individual fluxes for each site, site characteristics, } \\
\text { volume of bubbles, } \mathrm{CH}_{4} \text { concentration, time } \\
\text { accumulated }\end{array}$ & 771 \\
\hline & Daily mean flux for 2 vegetation categories & 51 \\
\hline \multirow{2}{*}{$\begin{array}{l}\text { Gross Bubble Storage } \\
\text { and Production }\end{array}$} & $\begin{array}{l}\text { Volume and concentration of bubbles released by } \\
\text { prodding from } 2 \text { sites }\end{array}$ & 2 \\
\hline & $\begin{array}{l}\text { Volume and concentration of bubbles accumulated } \\
\text { since first prodding, and released by further prodding }\end{array}$ & 2 \\
\hline \multirow{2}{*}{$\begin{array}{c}\text { Dissolved } \mathrm{CH}_{4} \\
\text { Storage }\end{array}$} & \begin{tabular}{|l} 
Porewater $\mathrm{CH}_{4}$ concentrations from 15 piezometers \\
\end{tabular} & 286 \\
\hline & Mass of dissolved $\mathrm{CH}_{4}$ stored in porewaters & 64 \\
\hline $\begin{array}{l}\text { Water Column } \\
\mathrm{CH}_{4} \text { Profiles }\end{array}$ & Concentrations of $\mathrm{CH}_{4}$ dissolved in the water column & $\begin{array}{c}21 \\
\text { profiles }\end{array}$ \\
\hline $\begin{array}{c}\text { Sediment-Water } \\
\text { Interface } \mathrm{CH}_{4} \text { Profiles } \\
\end{array}$ & $\begin{array}{l}\text { High resolution profiles of dissolved } \mathrm{CH}_{4} \\
\text { concentrations across the sediment-water interface }\end{array}$ & $\begin{array}{c}10 \\
\text { profiles }\end{array}$ \\
\hline \multirow{4}{*}{$\begin{array}{l}\text { Sediment-Water } \\
\text { Chamber Fluxes }\end{array}$} & $\begin{array}{l}\text { Individual fluxes measured in benthic chambers, time } \\
\text { and site characteristics (vegetation water depth) }\end{array}$ & 39 \\
\hline & \begin{tabular}{|l} 
Daily mean benthic chamber flux \\
\end{tabular} & 12 \\
\hline & Individual benthic chamber fluxes with MF inhibition & 10 \\
\hline & \begin{tabular}{|l} 
Daily mean MF-inhibited benthic chamber flux \\
\end{tabular} & 2 \\
\hline \multirow{4}{*}{$\begin{array}{l}\text { Sediment } \\
\text { Incubations }\end{array}$} & $\begin{array}{l}\text { Individual sample } \mathrm{CH}_{4} \text { production potentials, dry } \\
\text { weight, organic matter content (loss on ignition) }\end{array}$ & 51 \\
\hline & mean $\mathrm{CH}_{4}$ production potential for each depth & 17 \\
\hline & $\begin{array}{l}\text { Individual sample } \mathrm{CH}_{4} \text { consumption potentials, dry } \\
\text { weight, organic matter content (loss on ignition) }\end{array}$ & 34 \\
\hline & mean $\mathrm{CH}_{3}$ consumption potential for each depth & 17 \\
\hline \multirow{4}{*}{$\mathrm{C}$ and $\mathrm{H}$ isotopes } & $\delta^{13} \mathrm{C}$ and $\delta \mathrm{D}$ of $\mathrm{CH}_{4}$ in naturally released bubbles & 30 \\
\hline & $\delta^{13} \mathrm{C}$ and $\delta \mathrm{D}$ of $\mathrm{CH}_{4}$ in prodded bubbles & 2 \\
\hline & $\delta^{13} \mathrm{C}$ and $\delta \mathrm{D}$ of $\mathrm{CH}_{4}$ dissolved in porewater & 12 \\
\hline & $\delta^{13} \mathrm{C}$ and $\delta \mathrm{D}$ of $\mathrm{CH}_{4}$ in the water column & 2 \\
\hline
\end{tabular}




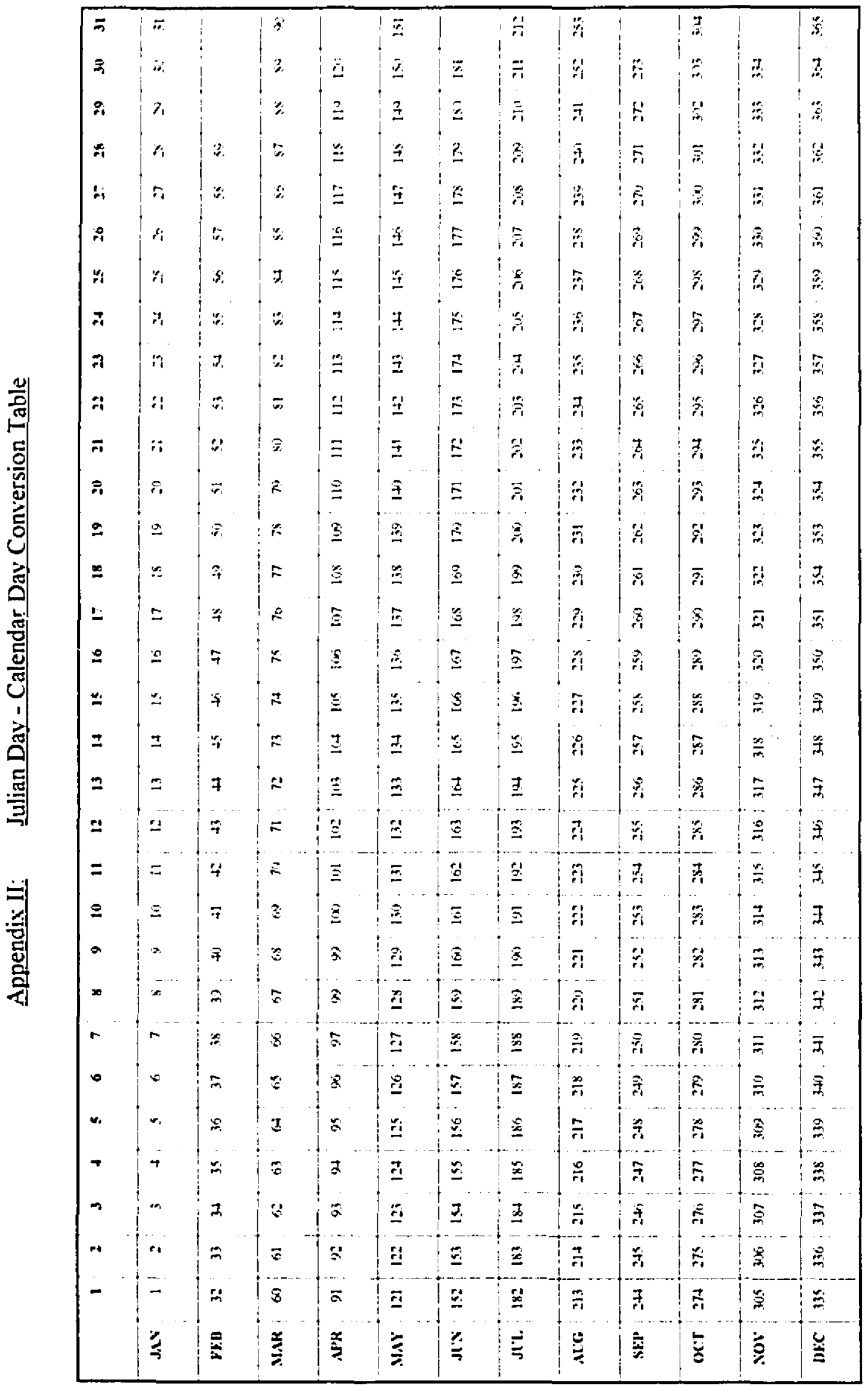

